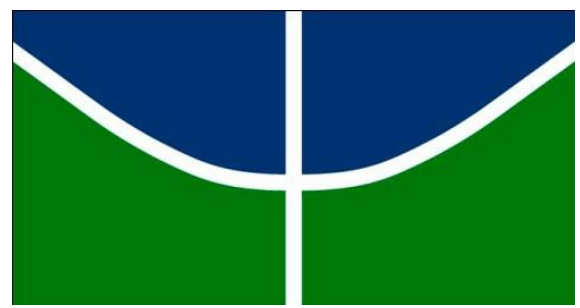

UNIVERSIDADE DE BRASÍLIA

Instituto de Ciências Biológicas - Instituto de Física - Instituto de Química Faculdade UnB Planaltina

Programa de Pós-Graduação em Ensino de Ciências

Mestrado Profissional em Ensino de Ciências

FORMAÇÃO CONTINUADA DE PROFESSORES:

UMA PESQUISA COLABORATIVA SOBRE EDUCAÇÃO AMBIENTAL COM DOCENTES DE ANOS INICIAIS DO ENSINO FUNDAMENTAL

TÂMIA TELES DE MENEZES PEREIRA

Brasília, DF 


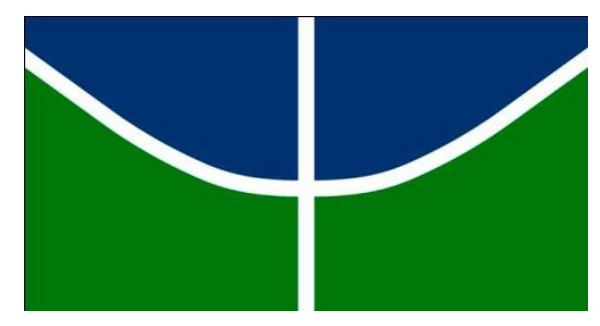

UNIVERSIDADE DE BRASÍLIA

Instituto de Ciências Biológicas - Instituto de Física - Instituto de Química Faculdade UnB Planaltina

Programa de Pós-Graduação em Ensino de Ciências

Mestrado Profissional em Ensino de Ciências

FORMAÇÃO CONTINUADA DE PROFESSORES:

UMA PESQUISA COLABORATIVA SOBRE EDUCAÇÃO AMBIENTAL COM DOCENTES DE ANOS INICIAIS DO ENSINO FUNDAMENTAL

Tâmia Teles de Menezes Pereira

Dissertação apresentada ao curso de Mestrado Profissional em Ensino de Ciências, do Programa de Pós-Graduação em Ensino de Ciências da Universidade de Brasília, como requisito parcial para obtenção de título de mestre.

Orientação: Prof ${ }^{\mathrm{a}}$. Dra ${ }^{\mathrm{a}}$. Maria Rita Avanzi

Brasília, DF 
FOLHA DE APROVAÇÃO

TÂMIA TELES DE MENEZES PEREIRA

\title{
FORMAÇÃO CONTINUADA DE PROFESSORES: UMA PESQUISA COLABORATIVA SOBRE EDUCAÇÃO AMBIENTAL COM DOCENTES DE ANOS INICIAIS DO ENSINO FUNDAMENTAL
}

\begin{abstract}
Dissertação apresentada ao curso de Mestrado Profissional em Ensino de Ciências, do Programa de Pós-Graduação em Ensino de Ciências da Universidade de Brasília, como requisito parcial para obtenção de título de mestre.
\end{abstract}

Aprovada em

Banca Examinadora:

Prof $^{\mathrm{a}}$. Dr ${ }^{\mathrm{a}}$. Maria Rita Avanzi

(Presidente)

Prof. Dr. Irineu Tamaio

(Membro externo não vinculado ao programa - UNB)

Prof $^{\mathrm{a}}$. Dr ${ }^{\mathrm{a}}$. Maria Luíza de Araújo Gastal (Membro interno vinculado ao programa - NECBIO/UNB) 
Ficha catalográfica elaborada automaticamente, com os dados fornecidos pelo(a) autor(a)

PP436f Pereira, Tâmia T. M.

Formação continuada de professores: uma pesquisa colaborativa sobre Educação Ambiental com docentes de Anos Iniciais do Ensino Fundamental / Tâmia T. M. Pereira; orientador Maria Rita Avanzi. -- Brasilia, 2017.

$129 \mathrm{p}$.

Dissertação (Mestrado - Mestrado

Profissionalizante em Ensino de Ciências) --

Universidade de Brasilia, 2017.

1. Narrativas autobiográficas. 2. Açăo de formação continuada em EA. 3. Educaçăo Ambiental crítica. 4. Professor reflexivo. I. Avanzi, Maria Rita, orient. II. Titulo. 


\section{DEDICATÓRIA}

A Jesus, autor e consumador da minha fé,

Aos meus pais, eterna gratidão,

À minha vozinha, exemplo de sabedoria,

Aos meus sobrinhos, Esther, Ruth e André, por compartilharem comigo a sabedoria infantil! 


\section{AGRADECIMENTOS}

É melhor haver dois do que um, porque duas pessoas trabalhando juntas podem ganhar muito mais Eclesiastes 4:9

À Deus, que me sustentou em Seu infinito amor, à Ele toda honra e glória, hoje e sempre.

Ao pastor Araújo e dn Graça, paizinho e mãezinha, suas mãos de amor me guiaram a um caminho de excelência, o exemplo de vocês estará sempre comigo.

Aos meus irmãos, por sonharem junto comigo, pelo incentivo, pelas palavras mágicas na hora do sufoco, pelas mãos estendidas e carinho. Vocês também são mestres!

À minha querida orientadora, professora Maria Rita Avanzi, por me apresentar o mundo da pesquisa sem perder a doçura do 'ser' humano, por me estender as mãos e tecer junto este artesanato. Gratidão pelos diálogos, reflexões e palavras de incentivo, por compartilhar sua atenção, sabedoria, respeito e amor pela profissão professor e Educação Ambiental.

À minha banca: professora Maria Luíza de Araújo Gastal, querida Malu, por compartilhar a 'experiência', seus saberes e momentos preciosos de estudo. Ao professor Irineu Tamaio, pelo aceite do convite e pelas contribuições na construção desse projeto.

Ao CEF 115, por abrir as portas para mais uma incrível experiência na minha vida, à equipe gestora, minhas amigas, eterna gratidão!

As professoras, companheiras na ação de formação, por aceitarem o desafio da formação continuada e construção coletiva desse projeto. Continuo aprendendo com vocês.

Aos meus amigos e amigas, sem a alegria, o incentivo e o amor de vocês nada disso seria possível.

Aos meus familiares, em especial, minha vozinha, dn Esperança, por seus ensinamentos e amor.

Aos professores e colegas do PPGEC, por compartilharem seus saberes e sentimentos.

Muito Obrigada!!! 


\section{RESUMO}

Com objetivo geral de investigar potencialidades e desafios de uma ação de formação continuada em Educação Ambiental (EA) de professoras do $4^{\circ}$ e $5^{\circ}$ ano do ensino fundamental no espaço escolar, esta dissertação visa contribuir com reflexões sobre profissionalização docente e práticas de EA na escola, na perspectiva de uma práxis transformadora no ambiente escolar. Parte da experiência da autora como professora, coordenadora e supervisora pedagógica da rede pública do Distrito Federal e busca responder as seguintes questões: Como os professores se preparam para trabalhar EA com os alunos? O que entendem por EA e como a relacionam com os currículos e projetos da escola? Há, para esses professores, relação entre EA, conteúdo curricular e formação crítica dos sujeitos? A pesquisa qualitativa foi escolhida como metodologia para o trabalho, que se desenvolveu como uma pesquisa-intervenção educativa de cunho colaborativo. Os dados analisados decorreram das entrevistas e dos encontros realizados durante a ação de formação, realizada dentro do espaço escolar, os quais foram submetidos à análise de conteúdo a partir da construção de categorias sobre formação continuada e EA. A análise da EA se deu a partir de três eixos: concepções sobre EA; EA e a prática pedagógica; EA e formação dos sujeitos. A respeito de formação continuada, foram identificadas compreensões associadas à capacitação ou instrumentalização; atualização ou aquisição de informação e aplicação prática. Os resultados obtidos indicam a necessidade de uma formação continuada que seja pautada pela reflexão, levando em consideração o protagonismo docente no seu desenvolvimento profissional, superando o tecnicismo e considerando a práxis manifesta na ação docente com a preocupação da formação crítica dos sujeitos. Ainda que estejam presentes práticas educativas marcadas pela transmissão de informações e pela busca de comportamentos ecologicamente corretos, foi possível perceber indícios de uma EA crítica a partir de concepções e práticas de formação de sujeitos nos projetos desenvolvidos pelas professoras. Ressaltamos a importância de ações de formação continuada em EA que estimulem o diálogo e um olhar complexo sobre as questões ambientais, buscando a construção de um novo saber e de valores afinados com uma racionalidade ambiental. Além desta dissertação, a pesquisa desenvolvida resultou em uma proposição de ação profissional sobre formação continuada de professores em EA.

Palavras-chaves: narrativas autobiográficas, ação de formação continuada em EA, EA crítica e Professor reflexivo. 


\section{ABSTRACT}

In order to investigate the potentialities and challenges facing continuing education action in Environmental Education (EE) of elementary school teachers in the scholastic environment, this master's thesis aims to contribute with thoughts about teacher professionalization and EE practices at the school, in the perspective of a transformative praxis in the scholastic environment. It comes from the authors experience as a teacher, pedagogical coordinator and supervisor of Distrito Federal public schools in Brazil, and it tries to answer the following questions: How do the teachers prepare themselves to work with EE with the students? What do they understand about EE and how do they relate EE with curriculum and critical formation of the subjects? The qualitative research was chosen as methodology for the work which was developed as a collaborative educational intervention research. The analyzed data took place form interviews and meetings conducted during the formation, inside the school environment, which were submitted to the analysis of content from the categories construction about continued training of teachers and EE. The EE analysis came from three axes: conceptions about EE; EE and pedagogical practices; EE and personnel training. Related to the continued training, it was identified that understandings associated with training or instrumentalisation; information update or acquisition and practical application. The obtained results indicate the need of a continued training that be guided by thoughts, taking into account the teachers role in its professional development, overcoming the technicality and considering the praxis manifest in the teaching action with the concern of the critical training of people. Although there are educational practices marked by the transmission of information and the search for ecologically correct behaviour, it was possible to realize signs of a critical EE from the conceptions and practices of training people in the projects developed by the teachers. We emphasize the importance of continued training in EE that encourages dialogue and a complex look at environmental issues, seeking the construction of new knowledge and values close to environmental rationality. In addition to this master thesis, the research developed resulted in a professional action about the continued training of teachers in EE.

Keywords: autobiographical narratives; EE continuing education action; critical environmental education and reflective teacher. 


\section{LISTA DE ABREVIATURAS E SIGLAS}

EA - Educação Ambiental

IES - Instituições de Ensino Superior

ONU - Organização das Nações Unidas

PNEA - Política Nacional de Educação Ambiental

DCNEB - Diretrizes Curriculares Nacionais da Educação Básica

DCNEA - Diretrizes Curriculares Nacionais para a Educação Ambiental 


\section{SUMÁRIO}

APRESENTAÇÃ̃ - Artesanato e pesquisa: o encontro de duas artes .......................... 13

CAPÍTULO 1 - Delimitando nosso projeto: uma colcha de retalhos ................................ 17

CAPÍTULO 2 - Uma colcha de retalhos: a escolha dos nossos tecidos e formatos ......... 23

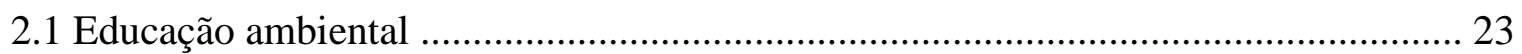

2.1.1 Consciência e conscientização ............................................................... 30

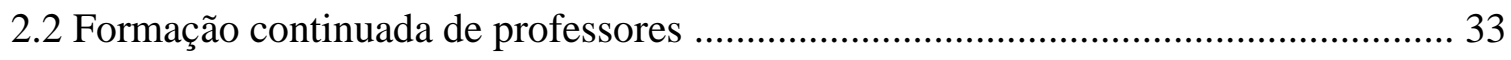

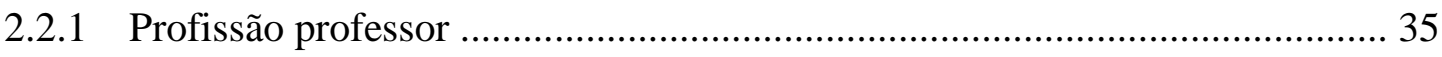

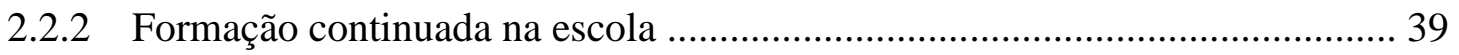

2.2.3 Produção de narrativas e formação docente .................................................. 40

CAPÍTULO 3 - Entre tecidos, técnicas e feitios: a pesquisa colaborativa como uma

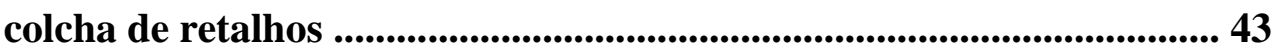

3.1 Observação participante ................................................................................ 44

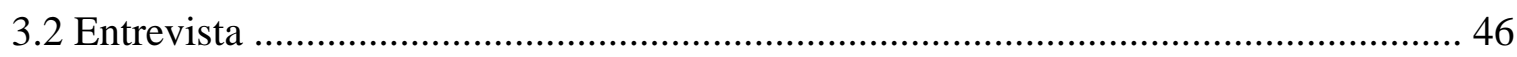

3.3 Ação de formação continuada: a escola como espaço para a formação ..................... 47

3.3.1 Tecendo a colcha de retalhos: descrição dos Encontros ................................. 48

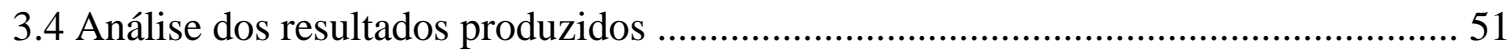

CAPÍTULO 4 - Uma colcha de retalhos: possíveis formatos ........................................... 55

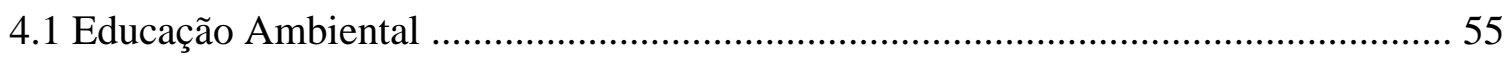

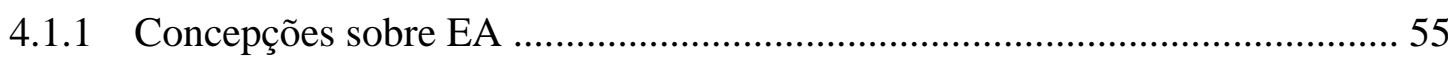

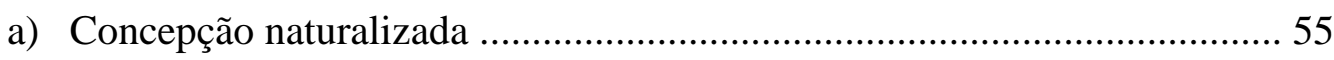

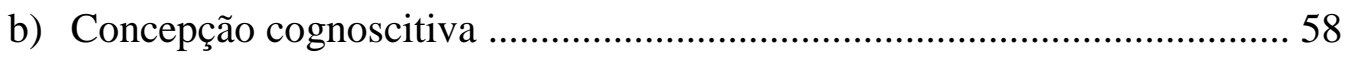

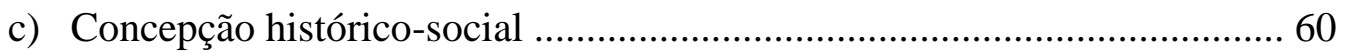

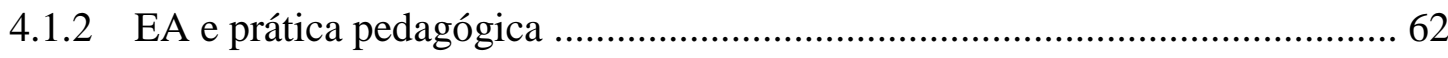

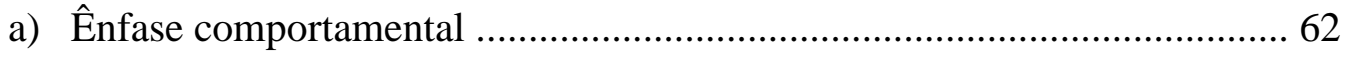

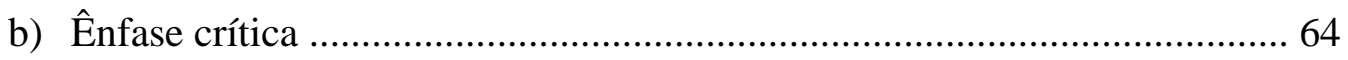

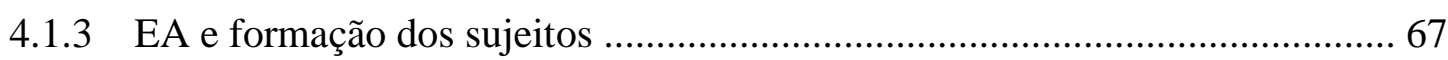

a) Conscientização como repasse de informações ......................................6 67

b) Conscientização como processo reflexivo .............................................. 69

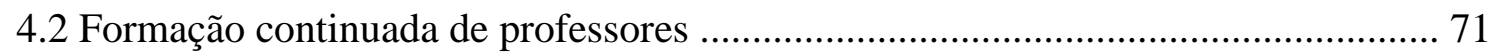

a) Formação como capacitação ou instrumentalização ................................ 73

b) Formação como atualização ou aquisição de informação .......................... 76 
c) Formação como relação teoria e prática docente 78

CAPÍTULO 5 - Narrativas e formação continuada: conectando tecidos e aplicações .. 83

CAPÍTULO 6 - Possíveis alinhamentos e arremates 95 REFERÊNCIAS BIBLIOGRÁFICAS 101 APÊNDICES

Apêndice I - Termo de consentimento livre e esclarecido (TLCE) 107

Apêndice II - Ação de formação: planejamento inicial 109

Apêndice III - Proposição didática 113 ANEXOS

Anexo I - Poesia “Artesã” 129 


\title{
APRESENTAÇÃO
}

\section{Artesanato e Pesquisa: o encontro de duas artes}

\author{
Da desordem, vem ordem \\ Se quem contempla é visionário \\ Criando, reúne os diferentes, \\ Faz da desordem, o belo \\ (Walter da Mata)
}

O interesse pelas questões ambientais e pela formação de professores surge da minha experiência durante a graduação e como professora da rede. Foram momentos distintos, mas que permitiram e apoiaram minha decisão em continuar meus estudos com o mestrado.

O fio condutor que une os temas é a noção de experiência, aqui com o sentido apresentado por Larrosa (2002, p. 21) “A experiência é o que nos passa, o que nos acontece, o que nos toca", diferente de um acontecimento ou uma informação externos, a experiência possibilita uma transformação no sujeito que a vivencia, ela requer de nós um ato de interrupção, ou seja, a sensibilidade em parar para pensar, olhar, escutar e sentir, cultivando a atenção e o cuidado (LARROSA, 2002).

Dentro da perspectiva de uma formação crítica dos sujeitos, acredito que a EA contribua significativamente, pois ela possibilita pensarmos as relações estabelecidas historicamente entre o ser humano e o ambiente, não sendo apenas uma relação distante ou uma abordagem utilitária da natureza, mas uma relação que se configura socialmente. A EA para professores se faz necessária, não apenas pela legislação, mas porque acredito também na formação continuada como um dos processos de profissionalização dos docentes.

Uma das minhas inquietações sobre os cursos de formação continuada que já havia feito era a forma como eram conduzidos, muitas vezes distantes da minha realidade, outras vezes com caráter de "capacitação" ou "reciclagem", e quase sempre não oportunizando minha participação no processo formativo.

Inserida no contexto escolar, noto que muitos são os desafios enfrentados por nós, professores, na tentativa de exercer a docência e atingir seu objetivo principal/primordial, a formação do sujeito. Um dos dilemas apresentados pelos professores, nas conversas informais, é a dúvida sobre o que deve ser ensinado. Frequentemente encontramos perguntas do tipo: ensinar os conteúdos ou formar o aluno para a vida? Como dar conta do extenso currículo e ainda assim, pensar sobre a formação crítica dos alunos? Como trabalhar o conteúdo e ainda inserir os projetos exigidos pela escola/Secretaria de Educação? 
Outros aspectos que interferem na prática docente são: a desarticulação da gestão, alunos desmotivados, professores que apenas cumprem a carga horária, falta do planejamento pedagógico e administração da gestão escolar. Além de outros projetos que são demandados às escolas pela própria comunidade escolar, como por exemplo: violência, indisciplina, drogas, gravidez precoce, entre outros. Temos ainda outros assuntos que estão presentes nas Diretrizes Curriculares e nas políticas públicas afirmativas como, por exemplo: as Diretrizes Curriculares Nacionais para a Educação das Relações Étnico-Raciais e para o Ensino de História e Cultura Afro-Brasileira e Africana e as Diretrizes Nacionais para a Educação em Direitos Humanos, além da própria Educação Ambiental (EA). Entendo que todos os assuntos são relevantes para a formação do sujeito, o que me preocupa é como os professores, que estão inseridos nas escolas, são preparados para atender tais demandas.

Na tentativa de corresponder aos meus anseios como professora da rede pública de ensino, e pelo encantamento que sempre tive pela EA, busquei construir um projeto de formação continuada que fosse significativo aos participantes, incluindo-me entre eles. Mesmo que as escolhas para a confecção desse artesanato estejam pautadas nas minhas experiências, entendo que o trabalho artesanal aqui desenvolvido foi feito a várias mãos, por isso não posso considerar um trabalho meu, mas nosso.

A escola que escolhemos para desenvolver nosso projeto está localizada na região administrativa do Recanto das Emas, Centro de Ensino Fundamental 115. Em 2009, atuei como supervisora pedagógica nesta escola e pude vivenciar, conviver e me encantar com o universo dos Anos Iniciais do Ensino Fundamental. Nesse período, busquei aprender mais sobre Anos Iniciais, fiz alguns cursos de formação continuada, porém considero que a formação mais importante foi a que fiz com as próprias professoras da escola, pois aprendia com elas na vivência de sala de aula e na supervisão pedagógica.

Remetendo à ideia de artesã, ao fabricar uma peça não pensamos de imediato no retorno financeiro ou no trabalho que teremos, mas, e principalmente, na possibilidade de encantar e fazer feliz a pessoa que receberá o produto. Se pensarmos em uma colcha de retalhos, um dos primeiros passos a ser tomado é tentar conhecer a pessoa que receberá o mimo, entender suas peculiaridades nos ajuda nas tomadas de decisões quanto às cores, técnicas e formatos que serão utilizados.

Assim, nossa pretensão não é entregar um trabalho pronto, mas com possibilidades de reajustes conforme a realidade e a necessidade de cada escola e profissional. A escola é um 
universo rico sendo possível a realização de trabalhos que forneçam a formação dos sujeitos, entre eles o professor.

Nosso trabalho está organizado em cinco capítulos. No primeiro capítulo, apresentamos o contexto da formação de professores, em especial, na EA, baseado em alguns autores, justificamos nossa escolha e apresentamos os objetivos da pesquisa.

O segundo capítulo apresenta o referencial teórico sobre EA e formação continuada de professores que embasa nossa pesquisa. O capítulo seguinte busca esclarecer as escolhas que fizemos em trabalhar com a pesquisa qualitativa, as técnicas e instrumentos utilizados, como também descreve a ação de formação realizada na escola. O quarto capítulo traz os resultados e discussões produzidos por meio da reflexão e análise de conteúdo. No quinto capítulo apresentamos o potencial das narrativas no processo de formação continuada.

O último capítulo traz considerações finais sobre a pesquisa desenvolvida e possíveis continuidades. Entendemos que não é um trabalho pronto, mas uma proposta que pode contribuir para a construção de ações de formação continuada em EA. 


\title{
CAPÍtULO 1
}

\section{Delineando nosso projeto: uma colcha de retalhos}

Sabemos que a formação do sujeito não ocorre somente na escola, ou seja, ela acontece nos espaços não formais e informais e é de responsabilidade de todos: Estado (poder público), a família, a sociedade e a escola (BRASIL, 2013). Nosso objetivo não está em discutir todos os atores responsáveis por essa formação, mas refletir sobre o papel da escola sendo representado pelos professores, pois acreditamos em um ensino público de qualidade ao qual o aluno tem direito, por ser um sujeito de diretos (o que inclui a consciência de seus deveres). Portanto, este trabalho visa contribuir com o desempenho do professor como agente responsável e direto dessa formação.

Conforme estabelecido nas Diretrizes Curriculares Nacionais para Educação Básica, em sua apresentação,

\footnotetext{
a Educação Básica de qualidade é um direito assegurado pela Constituição Federal e pelo Estatuto da Criança e do Adolescente. [...] A educação deve proporcionar o desenvolvimento humano na sua plenitude, em condições de liberdade e dignidade, respeitando e valorizando as diferenças. (BRASIL, 2013, p. 4)
}

Mais à frente o documento diz que:

\begin{abstract}
A Educação Básica é direito universal e alicerce indispensável para a capacidade de exercer em plenitude o direito à cidadania. É o tempo, o espaço e o contexto em que o sujeito aprende a constituir e reconstituir a sua identidade, em meio a transformações corporais, afetivo-emocionais, socioemocionais, cognitivas e socioculturais, respeitando e valorizando as diferenças. Liberdade e pluralidade tornam-se, portanto, exigências do projeto educacional. (BRASIL, 2013, p. 17)
\end{abstract}

Quando pensamos na formação docente e no professor como um dos responsáveis por sua própria formação, nos perguntamos: quais competências devem ter os profissionais da educação? Como deve ser a sua formação?

A formação de professores sempre esteve presente na história da educação brasileira. A partir de 1934, os Institutos da Educação foram incorporados às Universidades, com isso, 
abriram-se cursos para a "formação de professores para as escolas secundárias" (SAVIANI, 2009, p. 146).

Conforme o Dicionário Brasileiro Globo, "formação tem sentido de formar, construir, maneira pela qual se constitui uma mentalidade, um caráter" (FERNANDES, 1998, s/p), que por sua vez está em processo de interação e de transformação de conhecimentos e, para nós, apresenta caráter inicial ou contínuo. A formação inicial é a que se faz nas faculdades e universidades. A continuada acontece durante o processo em que o professor já está engajado na prática pedagógica. Assumimos e entendemos que a formação é um processo individual, coletivo e contínuo. Conforme Bandeira (2006),

Pensar em educação pressupõe pensar a formação docente e a prática pedagógica com qualidade. Para tanto se faz necessário entender a formação do professor para o desenvolvimento dos saberes docentes, o que exige qualificação, valorização profissional e políticas adequadas, considerando o lócus de trabalho do professor. (BANDEIRA, 2006, p. 2)

Saviani (2009) apresenta que mesmo com as mudanças ocorridas na formação de professores ao longo dos anos no Brasil, ainda é necessário que ocorram mudanças consideráveis nessa área. O autor faz uma análise histórica e teórica do problema da formação dos professores no contexto brasileiro. Do ponto de vista teórico, são apresentados dois modelos de formação: o modelo dos conteúdos culturais-cognitivos - presente na formação profissional apenas dos conteúdos específicos da área de conhecimento, e o modelo pedagógico-didático, que considera a formação do professor no efetivo preparo pedagógico. Por não haver diálogo entre esses modelos de formação, surge um dilema: como podemos articular os conteúdos e procedimentos que são ensinados nas licenciaturas aos procedimentos didático-pedagógicos?

Miguel Arroyo (1999), em seu artigo "Ciclos de Desenvolvimento Humano e Formação de Educadores", nos leva a refletir sobre como tem ocorrido a formação dos professores perante às demandas sociais. Conforme o autor, tradicionalmente a formação, tanto de alunos como de professores, antecede a prática, ou seja, "ao tempo de fazer terá de preceder o tempo de aprender a fazer" (p. 146). Argumenta que essa concepção de educação divide em dois tempos a vida: o de aprender e o de fazer, teoria e prática, formação e ação, e que esse tipo de educação tem marcado a formação e qualificação dos professores. 
Ainda sobre essa formação, Arroyo (1999) apresenta a visão tecnicista como utilitária e mercantil, formando apenas profissionais que executam tarefas e que esse papel muda conforme muda a conjuntura. Com isso:

os futuros profissionais da escola e aqueles que nela trabalham internalizaram a concepção precedente: só interessa aprender o que os prepare para tarefas concretas, para intervenções pontuais.

(...)

Rotulo de tradicional essa forma de pensar a formação de profissionais da educação básica porque é com essa lógica que temos equacionado em nossa tradição pedagógica as políticas de formação, currículos e as competências requeridas dos mestres. Estes aparecem como super-heróis que em cada conjuntura, em cada cena do filme, tem de dar conta das novas competências, dos novos conhecimentos, conteúdos e técnicas, das incumbências (termo comum usado nos pareceres oficiais dos conselhos) que lhes são atribuídas pelas leis, pelas reformas curriculares, pelas políticas oficiais, ou, como agora se diz, demandas pelos avanços da sociedade do conhecimento, da informática e das tecnológicas. (ARROYO, 1999, p. 147-9)

Dentro desse contexto nos preocupamos em como o professor se percebe na sua formação, o que entende dessa profissão e quais são as suas atribuições atuais. Em meio as demandas apresentadas às escolas, como ele percebe sua formação para atuar como educador ambiental?

O que podemos observar é que, mesmo com as leis existentes, ainda estamos longe de proporcionar a formação devida, tanto para os professores como para os alunos, por inúmeros fatores que influenciam direta ou indiretamente essa formação. A EA deveria estar presente na formação dos sujeitos, seja educandos ou educadores e é assegurada pela Lei 9795/99, que institui a Política Nacional de Educação Ambiental (PNEA) e estabelece a EA como componente obrigatório da educação brasileira, bem como seus princípios básicos e seus objetivos gerais.

Algumas autoras mencionam dificuldades na formação inicial dos docentes em EA. Santos (2015) discute, em sua tese de doutorado, questões relacionadas ao currículo de formação dos professores de Instituições de Ensino Superior (IES), que, entre outros fatores, apresenta a falta da formação crítica e aborda a EA em uma perspectiva fragmentada, conforme os currículos estudados pela autora. Outro fator que interfere na formação dos professores em EA é a forma como esta é conduzida nos cursos de formação. Mesmo quando 
presente nos currículos das IES, a visão fragmentada e descontextualizada prejudica o alcance dos seus objetivos. Tristão (2004) defende que a formação em EA está associada às capacidades de transformação social, ao resgate das relações homem/natureza e da responsabilidade do sujeito social em relação à degradação e exploração dos recursos naturais.

Podemos perceber, nas conversas informais com professores, que muitos não percebem as contribuições da EA na formação de uma cidadania crítica e participativa. As questões ambientais se resumem muitas vezes a programas de coleta seletiva e reciclagem, mas não há a abordagem histórica e contextualizada dos fatores ambientais.

Conforme Grün (2000) se há a necessidade de uma EA é porque o ambiente foi negado durante muito tempo no meio educacional, ou seja, a educação foi 'não ambiental'. O mesmo autor discute as modificações das relações dos humanos com a natureza a partir do advento da ciência moderna e como isso influenciou, e influencia até os dias atuais, a forma de tratar/ensinar o meio ambiente. A natureza vista como objeto está presente nos currículos e assim, intensifica-se a 'superioridade' do ser humano sobre ela.

Reconhecemos as fragilidades e dificuldades enfrentadas na formação inicial dos professores em alcançar parte dos objetivos da EA, no entanto, nossa preocupação neste trabalho dirige-se à formação continuada. Com base nesse contexto apresentado, esta pesquisa tem como questionamentos: como os professores se preparam para trabalhar EA com os alunos? O que entendem por EA e como a relacionam com os currículos e projetos da escola? Há, para esses professores, relação entre EA, conteúdo curricular e formação crítica dos sujeitos?

Acreditamos na autonomia do professor e que a EA possa auxiliar na formação do indivíduo como sujeito crítico e capaz de tomar decisões. Entendemos que a EA visa à formação crítica do indivíduo para atuar nas questões sociais em que estão inseridos e que essas refletem nas questões globais. A transformação passa pelo pensamento, gerando modificações no comportamento do ser humano e na sua relação com a natureza, incluindo outros humanos. Podemos também ressaltar a EA como proposta para a formação de novos valores a serem construídos e constituídos pela sociedade, nova ética, novo pensar social, o que Enrique Leff (2013) chama de racionalidade ambiental.

Quando pensamos em EA, consideramos as relações estabelecidas historicamente entre o ser humano e o ambiente que se traduzem socialmente. Por exemplo, quando levamos a ideia de um projeto sobre conservação das árvores, não visamos apenas o famoso "vamos 
plantar uma árvore", mas acreditamos na percepção do indivíduo e do sujeito social sobre o que é uma árvore. Quais relações são estabelecidas entre ser humano e árvore, historicamente? Por que plantar? O que acontece com o desmatamento? Quem se beneficia com o desmatamento? Quais os danos socioambientais causados pelo desmatamento? Quais atores sociais o promovem? Quais as consequências locais, regionais e globais do desmatamento?

Como a EA surge de demandas sociais, é necessário que o social seja incorporado e as demandas e ações promovidas pela EA voltem para essa sociedade, e, uma forma de isso acontecer é por meio da escola. A escola é um espaço privilegiado para que a formação crítica dos indivíduos ocorra. Quando pensamos na formação dos alunos, pensamos também na formação do professor, pois os dois, dentro do contexto escolar, são vistos como sujeitos de direitos e deveres. Logo, se consideramos que a EA para os alunos possibilita uma mudança de pensamento, consideramos que o professor também está inserido nesse processo.

O professor é visto como um dos responsáveis pela formação dos alunos, então, para que a formação ocorra, é interessante que o professor seja formado para ser formador.

Atendendo ao parágrafo único do artigo 11 da Lei 9795/99 pretendemos com este trabalho contribuir com a formação continuada dos professores realizando uma ação de formação com caráter colaborativo, dentro do ambiente escolar, que possibilite ampliar nossas concepções sobre EA e, por meio da reflexão, construir mudanças na prática pedagógica, fortalecendo a escola como um espaço para formação cidadã, trabalho coletivo e profissionalização docente.

Como objetivo geral pretendemos investigar as potencialidades e limites de uma ação de formação continuada em EA com professores de $4^{\circ}$ e $5^{\circ}$ anos do ensino fundamental, dentro do espaço escolar, visando contribuir com reflexões sobre a profissionalização docente e sobre práticas de EA na escola, contribuindo para uma práxis transformadora no ambiente escolar.

Apresentamos os objetivos específicos em duas linhas de atuação: Investigação:

- refletir sobre o papel da escola na formação coletiva dos docentes, em uma perspectiva colaborativa e participativa;

- estudar o potencial reflexivo e formativo das narrativas autobiográficas. 
Formação:

- estimular docentes a incorporar uma postura dialógica e reflexiva em sua prática profissional;

- contribuir para a formação do sujeito ecológico;

- construir propostas de ações de EA para o ambiente escolar que visem o fortalecimento do Projeto Político Pedagógico. 


\title{
CAPÍTULO 2
}

\section{Uma colcha de retalhos: a escolha dos nossos tecidos e formatos}

\author{
De panos, zíperes, linhas e botões \\ Dispostos em criatividade \\ Nascem bolsas, almofadas e mil idéias \\ Na mente e mãos de hábeis artesãs \\ (Walter da Mata)
}

\subsection{Educação Ambiental}

Conforme contexto histórico, a EA foi proposta em meio à insatisfação de parte da sociedade em relação ao modelo econômico, de consumo e de desenvolvimento tecnológico e científico vigentes nas décadas de 1960 e 1970.

A partir da década de 1970, foram promovidas pela Organização das Nações Unidas (ONU) grandes conferências internacionais com o intuito de discutir e buscar soluções com o "objetivo de estabelecer uma visão global e princípios comuns para a preservação e melhoria do ambiente humano" (TANNOUS e GARCIA, 2008, p. 185). Entre elas, podemos destacar: Conferência de Estocolmo, em 1972; Encontro Internacional de Educação Ambiental, em 1975; Conferência de Tbilisi, em 1977, que já apresentavam em suas propostas a EA como um instrumento para a busca de uma cidadania plena e capaz de participar das decisões sociais, contribuindo para a formação de uma consciência crítica, que compreenda os problemas ambientais e o estímulo a formação de comportamentos positivos (TANNOUS e GARCIA, 2008).

Carvalho (2004) destaca a importância dos movimentos ecológicos das décadas de 1960 e 1970 que denunciavam os riscos ambientais e também criticavam o modo de vida das sociedades. Esses movimentos emergiram da sociedade na busca por igualdade social e liberdade e se posicionaram contrários ao modelo de desenvolvimento dominante, bem como "ao paradigma ocidental moderno, industrial, científico, questionando a racionalidade e o modo de vida da chamada Grande Sociedade" (p 47).

No Brasil, a preocupação com o meio ambiente e a consequente inserção desse tema nas esferas sociais, começa a partir dos anos 70, recebendo influências externas e internas. Ao mesmo tempo em que assistíamos no cenário internacional os movimentos ecológicos, também chamados de contracultura, tínhamos um cenário interno de repressão política, sendo assim, o movimento ganhou força com os movimentos sociais internos na busca por liberdade e combate às desigualdades sociais. (CARVALHO, 2004). 
A partir de então, as questões ambientais passaram a se inserir no cenário político brasileiro, sendo criadas secretarias, órgãos e decretos relacionados à temática ambiental que, em 1988, foi contemplada na Constituição Federal, artigo 5. Além dessas, outras medidas foram tomadas assim como a criação de outras Leis que amparam o Direito Ambiental. A Política Nacional da Educação Ambiental (PNEA) - Lei 9795/99, em seu artigo $1^{\circ}$ define a EA como "processos por meio dos quais o indivíduo e a coletividade constroem valores sociais, conhecimentos e habilidades, atitudes e competências voltadas para a conservação do meio ambiente, bem de uso comum do povo, essencial à sadia qualidade de vida e sua sustentabilidade".

Conforme mencionado por Carvalho (2004), a EA resulta de demandas dos movimentos ecológicos.

\footnotetext{
Assim, a EA é concebida inicialmente como preocupação dos movimentos ecológicos com uma prática de conscientização capaz de chamar a atenção para a finitude e a má distribuição no acesso aos recursos naturais e envolver os cidadãos em ações sociais ambientalmente apropriadas. É em um segundo momento que a EA vai se transformando em uma proposta educativa no sentido forte, isto é, que dialoga com o campo educacional, com suas tradições, teorias e saberes. (CARVALHO, 2004, p. 52)
}

Essa mesma autora destaca o papel que teve, para o contexto brasileiro, a Conferência da ONU sobre Desenvolvimento e Meio Ambiente, no Rio de Janeiro, em 1992, conhecida como ECO-92. Nessa conferência houve a formulação do Tratado de Educação Ambiental para Sociedades Sustentáveis e Responsabilidade Global, definindo os princípios da EA. O Tratado reconhece a EA como ato político, propõe a perspectiva interdisciplinar para compreender as relações existentes entre os seres humanos e o meio ambiente por meio das diversas áreas dos conhecimentos e saberes, bem como a valorização das diversas culturas. Nesse sentido, a EA tem despertado mudanças nas concepções e práticas pedagógicas. (CARVALHO, 2004)

Nessa visão, aspiramos por uma educação que

se propõe a ser uma educação interdisciplinar, transversal, de saberes, atitudes, sensibilidades, dialogando com novos problemas e produzindo reflexões, concepções, métodos e experiências, construindo novas bases para conhecimentos e 
valores, portadora de uma nova sensibilidade e uma postura ética, comprometida com um projeto de cidadania. (PERNAMBUCO, 2004, p 208)

A EA nos apresenta o desafio do trabalho interdisciplinar, ou seja, o romper a lógica do pensamento fragmentado e de uma abordagem reducionista. A busca pela compreensão da temática ambiental nos impele a reconhecer e ressignificar as relações complexas existentes entre Humano-Natureza e Humano-Humano, movendo o ato de conhecer a uma abertura além dos limites das disciplinas e buscando a promoção de um novo saber, o saber ambiental que visa compreender a complexidade existente nas relações sociedade e natureza. (CARVALHO, 2004)

A literatura nos apresenta uma diversidade de vertentes sobre a EA. Como comenta Carvalho (2004):

\footnotetext{
Como sabemos, as práticas agrupadas sob o conceito de educação ambiental têm sido categorizadas de muitas maneiras: educação ambiental popular, crítica, política, comunitária, formal, não formal, para o desenvolvimento sustentável, conservacionista, socioambiental, ao ar libre, para solução de problemas entre tantas outras. (p. 15)
}

Esta pesquisa se fundamenta na EA Crítica, uma vez que acreditamos na educação como um processo social e político, e que as questões ambientais são tratadas em um contexto histórico de relações complexas entre sociedade e natureza. É vista como uma prática social que visa fomentar a formação crítica e cidadã, pautada pela ressignificação de valores e atitudes de sujeitos capazes de participar ativamente das decisões. É necessário reconhecer que a EA necessita de "sujeitos sociais emancipados, isto é, autores de sua própria história... leitores críticos do seu mundo" (CARVALHO 2004, p. 18).

Assim, compreendemos que a formação de professores em EA tem como objetivo a formação de educadores ambientais como mediadores das relações entre os grupos sociais com os quais ele trabalha e o meio ambiente em que estão inseridos (CARVALHO, 2004). Para nós, formar o professor em EA é auxiliá-lo na reflexão sobre sua formação como sujeito ecológico, inserido em uma cultura, e que então seja capaz de auxiliar a formação dos estudantes.

No primeiro capítulo do livro Educação Ambiental: natureza, razão e história, Tozzoni-Reis (2004) nos apresenta a formação de educadores ambientais recebendo influências de condicionantes sociais, políticos e culturais, identificando três núcleos de 
representações sobre as relações entre humanos e natureza, a saber: sujeito natural, sujeito cognoscente e sujeito crítico.

O sujeito natural "indica a igualdade entre todos os elementos da natureza para voltar ao equilíbrio natural" (TOZZONI-REIS, 2004, p. 33). Nesta representação, o ser humano é visto como vilão, como um ser que perturba a natureza por não se submeter às suas leis originando a crise ambiental a partir da sua arrogância. Assim, para que haja o resgate de um suposto equilíbrio harmônico, ele precisa voltar a encontrar o seu lugar, já estabelecido naturalmente. Apresenta uma visão romantizada e com ideia da volta a um paraíso perdido.

$\mathrm{Na}$ representação sujeito cognoscente há um reconhecimento das desigualdades na relação, sendo que uma das causas da crise ambiental apontadas é a falta de conhecimento sobre as leis da natureza. Assim, o conhecimento passa a ter valor libertador, sendo necessário conhecer para preservar, ela "refere-se ao caráter utilitarista da relação dos indivíduos com o ambiente em que vivem: saber (conhecimentos técnicos e científicos) usar, para poder usar mais e sempre, mas sempre usar" (TOZZONI-REIS, 2004, p. 33-34). Nesta compreensão, a solução para a crise ambiental está na educação (como transmissão dos conhecimentos científicos) e no desenvolvimento da tecnologia.

A terceira tendência, apresentada pela autora como sujeito histórico, é marcada pela intencionalidade dos sujeitos em relação à natureza. Esses sujeitos levam em consideração as condições históricas, sociais, políticas, econômicas e culturais na relação humanos-natureza. “A ideia síntese é que essa relação é construída pelas relações sociais: a história e a cultura são condicionantes e mediadoras, conferindo-lhe um caráter sócio-histórico" (TOZZONIREIS, 2004, p. 34). Assim, a relação humanos-natureza passa a ser entendida como sociedade-natureza e os problemas existentes emergem da forma como essa relação acontece, sugerindo, portanto, uma "nova ética" como possível caminho para o enfrentamento da crise ambiental.

Essas relações entre seres humanos e natureza foram constituídas historicamente. Carvalho (2004) nos apresenta como "as diferentes experiências históricas constituem um repertório de compreensões das relações com o mundo natural e como tais experiências incidem sobre nossas visões contemporâneas do ambiente" (p. 93). Segundo a autora, essa experiência é marcada por dois momentos, um em que a natureza é tida como selvagem, portanto há necessidade de ser domada, e no segundo momento a natureza como boa e bela.

Essas duas visões sobre a natureza apresentadas por Carvalho (2004) - natureza selvagem e natureza boa e bela - foram construídas a partir da nossa história social, a forma 
como as sociedades percebem a natureza ao longo de sua formação determina suas concepções sobre natureza e meio ambiente, ou seja, nossas visões de ambiente e de natureza estão carregadas de sentidos culturais herdados e construídos socialmente.

Todos nós vivemos imersos em uma rede de sentidos culturais historicamente construídos e em permanente diálogo com os significados produzidos pelas gerações que nos antecederam através dos séculos. Assim, somos herdeiros diretos das experiências que marcaram as relações entre sociedade e natureza de nossos predecessores e, da mesma forma, deixaremos para a posteridade nosso legado. (CARVALHO, 2004, p. 104)

Se compreendermos que a formação para uma EA crítica é a transformação de valores e atitudes, podemos pensar em uma mudança de racionalidade que, conforme Leff (2013) nos apresenta, seria uma racionalidade ambiental. A EA apresenta uma nova ordem no pensamento, nas relações e na construção da sociedade. De acordo com este autor, a sociedade foi construída baseada em uma "racionalidade econômica e instrumental", moldando "os padrões tecnológicos, as práticas de produção, a organização burocrática e os aparelhos ideológicos do Estado" (p. 133). Nesse sentido, as questões ambientais apresentam a necessidade de uma reforma do pensamento e condução do Estado, de "incorporar normas ecológicas ao processo econômico e de criar novas técnicas para controlar os efeitos contaminantes e dissolver as externalidades socioambientais geradas pela lógica do capital" (p. 133).

As diferenças existentes entre a racionalidade econômica e a ecológica estão nos valores e nos paradigmas de conhecimento estabelecidos na sociedade. A proposta da racionalidade ambiental nos mostra a necessidade de um pensamento coletivo, no qual os interesses não são de grupos isolados, mas da sociedade.

Neste sentido, a racionalidade ambiental não é a expressão de uma lógica, mas o efeito de um conjunto de interesses e de práticas sociais que articulam ordens materiais diversas que dá sentido e organizam processos sociais através de certas regras, meios e fins socialmente construídos. (LEFF, 2013. p. 134)

Leff (2013) nos apresenta a educação como um possível caminho para as mudanças de paradigmas, comportamentos e valores para alcançar a sustentabilidade: "a educação 
ambiental como um processo gerador de novos valores e conhecimentos para a construção da racionalidade ambiental.” (p. 239).

Ao fazer uma análise da função social do uso de discursos recorrentes em EA, Tristão (2005) nos aponta para uma EA crítica que supere o modelo atual presente na sociedade, ou seja, uma superação da visão fragmentada e objetificada da natureza pela ética antropocêntrica, e contra os modelos de desenvolvimento com a exploração dos recursos naturais, acumulação e consumismo que sustenta o ideal de domínio do ser humano sobre a natureza e sobre o próprio ser humano.

Sobre esse atual modelo de desenvolvimento e conhecimento, Santos (2001) apresenta a racionalidade científica como forma dominante desde o século XVI com o advento da revolução científica. Entre outras características citadas pelo autor sobre esse paradigma da modernidade, temos uma ruptura do conhecimento científico com o senso comum e da natureza com a pessoa humana, a natureza é explicada através das leis, ou seja, o conhecer passa a ser quantificado, seguindo o modelo matemático, e há uma redução da complexidade, o mundo é visto como uma máquina, "um mundo estático e eterno a flutuar num espaço vazio, um mundo que o racionalismo cartesiano torna cognoscível por via da sua decomposição nos elementos que o constituem" (SANTOS 2001, p. 64).

Assim, no paradigma da modernidade temos duas formas principais de conhecimento: conhecimento-regulação e conhecimento-emancipação (SANTOS, 2001). Para o autor, o conhecimento-regulação assume a forma hegemônica do saber através da lógica da racionalidade cognitivo-instrumental como imposta às demais racionalidades.

Procuramos, portanto, na EA crítica uma possibilidade de reconfigurar o conhecimento-emancipação, apontando a solidariedade como uma possível forma de saber.

Conforme Santos (2001):

A ênfase na solidariedade converte a comunidade no campo privilegiado do conhecimento emancipatório. Acontece que, depois de dois séculos de desterritorialização das relações sociais, a comunidade não pode limitar-se a ser a territorialidade própria do espaço contíguo (o local) e a temporalidade própria do tempo miúdo (o imediato). Vivemos numa época de nexos opacos, locais-globais e imediatos-deferidos. [...] A neo-comunidade transforma o local numa forma de percepção do global, e o imediato numa forma de percepção do futuro. É um campo simbólico em que se desenvolvem territorialidades e temporalidades específicas que nos permitem conceber o nosso próximo numa teia intersubjetiva de reciprocidades. Como a nova subjetividade depende menos da identidade do que da reciprocidade, 
pode e deve ser construída à margem do antropocentrismo: a natureza, dita nãohumana, não nos sendo idêntica, é-nos recíproca na medida em que, por exemplo, a sua destruição acarreta a nossa própria destruição. Assim, a nossa subjetividade não se completa sem ela. (p. 81)

Sobre as comunidades, Santos (2001) faz referência:

São aquilo que chamei de neo-comunidades, territorialidades locais-globais e temporalidades imediatas-diferidas que englobam o conhecimento e a vida, a interação e o trabalho, o consenso e o conflito, a intersubjetividade e a dominação, e cujo desabrochar emancipatório consiste numa interminável trajetória do colonialismo para a solidariedade própria do conhecimento-emancipação. (p. 95)

Dentro dessas comunidades interpretativas há uma possibilidade de ruptura com os padrões da racionalidade cognitiva-instrumental, permitindo uma abertura a um novo saber, a solidariedade. A solidariedade, conforme Santos (2001), é uma das dimensões que possibilita a construção de um novo senso comum. Ela pressupõe uma nova ética, que não seja pautada na ética liberal - regida pela tecnologia e pela ciência, mas que tenha como pressuposto o princípio da responsabilidade, "preocupação ou cuidado que nos coloca no centro de tudo o que acontece e nos torna responsáveis pelo outro, seja ele um ser humano, um grupo social, a natureza, etc.” (p. 112).

Como já mencionamos, a EA crítica possibilita a formação crítica dos sujeitos propondo um novo pensamento. Morin (2015), em seu livro "A Cabeça bem-feita”, faz uma reflexão sobre os desafios do ensino na atualidade quanto a importância de se considerar o pensamento complexo em detrimento ao pensamento fragmentado, imposto pelo paradigma moderno.

Inerente à visão que parte dos saberes separados, compartimentalizados, disciplinares, há uma impossibilidade de reconhecer os conjuntos complexos, as interações e retroações entre partes e todos, as entidades multidimensionais e os problemas essenciais (MORIN, 2015).

Conforme Morin (2015):

Há, efetivamente, necessidade de um pensamento:

- que compreenda que o conhecimento das partes depende do conhecimento do todo e que o conhecimento do todo depende do conhecimento das partes; 
- que reconheça e examine os fenômenos multidimensionais, em vez de isolar, de maneira mutiladora, cada uma de suas dimensões;

- que reconheça e trate as realidades, que são, concomitantemente solidárias e conflituosas (como a própria democracia, sistema que se alimenta de antagonismos e ao mesmo tempo os regula);

- que respeite a diferença, enquanto reconhece a unicidade.

É preciso substituir um pensamento que isola e separa por um pensamento que distingue e une. É preciso substituir um pensamento disjuntivo e redutor por um pensamento do complexo, no sentido originário do termo complexus o que é tecido junto. (p. 89).

Dentro dessa formação de novos valores e pensamento podemos refletir sobre a formação do sujeito ecológico apresentado por Carvalho (2004). Esse sujeito ecológico traz consigo uma nova consciência e percepção quanto as relações consigo e com o outro, busca um novo estilo de vida que vai desde comportamentos e atitudes ecologicamente orientados a um novo modo de pensar e agir no socioambiente. Ele, então, apresenta um novo ideário ecológico, mesmo ainda sendo considerado um ideal utópico, esse sujeito ecológico apresenta uma postura ética e crítica, sua busca está em uma construção social mais justa e igualitária.

Nesse sentido, o sujeito ecológico não vive fora da sociedade, mas participa e constrói socialmente, no coletivo, ações que possibilitam uma sociedade transformada. Com isso, entendemos que a formação de professores em EA auxilia, antes de tudo, a formação do sujeito ecológico, auxiliando no processo de reflexão quanto às possíveis formas de compreender e atuar na sociedade em que vive.

\subsubsection{Consciência e Conscientização}

Como já mencionamos, a EA crítica pressupõe a formação de sujeitos situados histórica e socialmente, que compreendam as relações dos seres humanos com a natureza e com outros seres humanos, capazes de tomar decisões a partir de uma postura ética, que rompa com uma racionalidade instrumental e possibilite em novo pensar, uma nova racionalidade e um novo saber.

A partir da filosofia moderna, Pequeno (2007) apresenta uma construção histórica da noção de sujeito, reconhecendo seu caráter subjetivo e argumentando, portanto, que ele "se revela como uma 'pessoa' que existe no tempo e no espaço, dotada de pensamentos, percepções, sentimentos, desejos e motivações, cuja existência encontra na convivência com o outro as suas condições fundamentais de realização" (p. 189-190). 
O sujeito revela uma realidade psicológica, existencial moral e política e, por ser portador de direitos e deveres, é um sujeito-cidadão, "definido por sua individualidade, mas também por suas interrelações e experiências compartilhadas. Trata-se, pois, de um ser cognitivo, reflexivo, passional, moral, político e social" (PEQUENO, 2007, p. 190).

Ao considerar o homem como sujeito moral, livre e autônomo, convém perceber a emoção. Segundo Pequeno (2007);

[...] A emoção consiste na percepção de um valor, segundo a forma específica que uma situação representa em relação às necessidades, aos interesses e aos fins perseguidos pelo homem. Aqui as emoções podem encontrar um dos terrenos fundamentais de sua manifestação: o campo da moral.

As emoç̃os participam do processo de tomada de decisão, estando ainda presentes na maior parte dos comportamentos humanos. As emoções revelam o caráter ambivalente da condição humana, haja vista que elas expressam tanto aquilo que temos de biológico ou natural quanto o que em nós se manifesta determinado pelo universo cultural. As experiências emocionais indicam que o homem nem é um anjo destituído de desejos e impulsos, nem, tampouco, um animal-máquina incapaz de conter as forças primitivas que o animam. Deixar-se conduzir por elas tanto quanto resistir aos sues apelos são formas possíveis de expressão do humano que há em nós. Assim, antes de ser um signo de sua animalidade, a emoção representa aquilo que confere ao homem um caráter de humanidade. Até porque, podemos imaginar um homem destituído de racionalidade, porém é certamente impossível que um sujeito desprovido de emoção possa ser chamado de humano. E longe de colocar em perigo seu projeto de grandeza futura, as emoções são, muitas vezes, a própria condição de sua realização. Eis por que elas devem ser levadas em conta quando falamos em sujeito moral livre e autônomo. (p. 199)

Para Gastal e Avanzi (2016) é importante que a formação dos sujeitos reconheça os "múltiplos cenários em que conhecimentos, também múltiplos, são construídos e mobilizados" (p. 225), ou seja, superar uma formação pautada por um sujeito da razão, que descarta as emoções e se baseia apenas em conhecimentos científicos, na racionalidade instrumental; o que se busca é a formação de um sujeito epistêmico que está localizado em um tempo/espaço, inserido numa cultura, que se relaciona com o outro (GASTAL; AVANZI, 2016). Ao pensarmos sobre a formação dos sujeitos, as autoras consideram a importância de se reconhecer o par razão e emoção, pois as emoções representam um papel importante na capacidade de conhecer. 
A respeito da formação do sujeito ecológico, temos como entendimento a aprendizagem pautada por uma perspectiva freireana: "todo o aprendizado deve encontrar-se intimamente ligado à tomada de consciência da situação real vivida pelo educando" (WEFFORT, 1967, p. 5). Ao fazer referência à educação dos sujeitos, Freire a direciona para um homem-sujeito, ou seja, um sujeito participante de uma sociedade e que ao ser educado apresente uma "postura de auto-reflexão e de reflexão sobre seu tempo e seu espaço" (FREIRE, 1967, p. 36). Assim, ao proporcionar uma educação libertadora, que respeite o sujeito como pessoa, faz-se necessário trabalhar a ideia de conscientização.

Ao mencionar uma educação libertadora, Freire (1967) faz menção a uma das características únicas do ser humano, sua capacidade de relacionar-se, o homem está no mundo e está com o mundo. Assim, para que esse homem saia da condição de simples espectador é necessário uma educação que possibilite uma reflexão sobre si mesmo, sobre suas responsabilidades e sobre seu papel, quanto a história (temporalidade) e cultura (criatividade) em que está inserido.

Essa reflexão busca analisar os graus de compreensão da realidade nos condicionantes histórico-cultural, sendo o primeiro deles a passagem da intransitividade da consciência para o estado da transitividade ingênua. A esse grau de consciência destaca-se o "quase incompromisso entre o homem e a sua existência" (FREIRE, 1967, p. 58), ou seja, o homem, nesse contexto, não consegue perceber situações que estejam fora do seu alcance biologicamente vital, há, portanto, uma "limitação na sua esfera de apreensão" (p. 58).

A medida que o homem aumenta seu poder de compreensão e de repostas aos questionamentos bem como seu poder de dialogar, não somente com outros homens, mas também com o seu próprio mundo, ocorre a transitividade da consciência, ou seja, "seus interesses e preocupações agora, se alongam a esferas mais amplas do que à simples esfera vital" (FREIRE, 1967, p. 59).

Porém, a consciência transitiva, em seu primeiro momento, se caracteriza como ingênua, pois há uma simplificação na interpretação dos problemas podendo acarretar a distorção da transitividade ingênua, ou seja, nesse processo, algumas características, como fragilidade na argumentação e o gosto pelas explicações fabulosas (mágicas), podem conferir a esse estado de consciência uma "massificação das classes" (FREIRE, 1967).

O terceiro nível de consciência apresentado por Freire (1967) é a crítica: 
uma educação dialogal e ativa, voltada para a responsabilidade social e política, se caracteriza pela profundidade na interpretação dos problemas. Pela substituição de explicações mágicas por princípios causais. Por procurar testar os "achados" e se dispor sempre a revisões. Por despir-se ao máximo de preconceitos na análise de problemas e, na sua apreensão, esforçar-se por evitar deformações. Por negar a transferência de responsabilidade. Pela recusa a posições quietistas. Por segurança na argumentação. Pela prática do diálogo e não da polêmica. Pela receptividade ao novo, não apenas porque novo e pela não recusa ao velho, só porque velho, mas pela aceitação de ambos, enquanto válidos. Por se inclinar sempre a arguições. (p. 60)

Assim, temos na EA crítica a possiblidade, não única e inesgotável, de formação dos sujeitos a partir de uma educação que liberta através de uma consciência crítica e autônoma, apontando a formação como princípio dialógico, que abre caminhos para um novo saber, pautado na responsabilidade e nova postura ética, bem como a busca por uma nova racionalidade.

\subsection{Formação continuada de professores}

Entendemos que as mudanças ocorridas na sociedade refletem e exigem que as instituições educacionais também passem por um processo de transformação. Como já mencionamos, um dos objetivos primordiais da educação é que o educando seja formado cidadão capaz de tomar decisões, participante da nova sociedade. Para isso, a escola enfrenta o desafio de não ser apenas um local de transmissão de conteúdos, mas de formação cidadã em sua complexidade.

Muitos são os estudos sobre formação de professor, as discussões vão desde a formação inicial à continuada, ou permanente. Autores, como Nóvoa, Imbernón, Pimenta, Libâneo e Tardif nos mostram quais os pensamentos e propostas atuais para essa formação.

Para Imbernón (2011), se há mudanças sociais e essas afetam diretamente os espaços educacionais - chamados por ele de "instituições educativas" - espera-se que haja mudança também na formação docente.

Essa necessária renovação da instituição educativa e esta nova forma de educar requerem uma redefinição importante da profissão docente e que se assumam novas competências profissionais no quadro de um conhecimento pedagógico, científico e cultural revistos. Em outras palavras, a nova era requer um profissional da educação diferente. (IMBERNÓN, 2011, p. 12) 
A educação superior está contemplada na Lei 9394/96 - Lei de Diretrizes e Bases da Educação Nacional - como componente da educação escolar. Ela estabelece por finalidade, entre outros, estimular o conhecimento dos problemas do mundo presente, estabelecendo uma aproximação com a comunidade, promover uma abertura à participação da população e atuar em favor da universalização e do aprimoramento da educação básica, mediante a formação e capacitação de profissionais. Essa capacitação é feita pelas IES, representadas pelas universidades, faculdades e centro universitários.

A referida Lei apresenta a formação inicial, continuada e a capacitação dos professores sendo promovida pela União, Distrito Federal, Estados e Municípios em regime de colaboração. Preferencialmente, a formação inicial ocorre de forma presencial nas IES e a formação continuada pode ocorrer no local de trabalho ou na IES, podendo ser curso de educação profissional, curso superior ou pós-graduação.

A temática deste trabalho está na formação continuada, ou seja, na formação dos professores que já concluíram o curso superior e estão inseridos na prática pedagógica.

Conforme Almeida (2005, p. 12), entendemos a formação continuada como:

\footnotetext{
o conjunto de atividades desenvolvidas pelos professores em exercício com o objetivo formativo, realizadas individualmente ou em grupo, visando tanto ao desenvolvimento pessoal como profissional na direção de nos prepararmos para a realização de nossas atuais atividades ou de outras novas que se coloquem.
}

Sobre a formação continuada, Imbernón (2011) nos apresenta cinco linhas de atuação: reflexão do professor sobre a própria prática mediante análise; troca de experiência entre os pares, o que possibilita o diálogo entre os professores; união e formação do projeto político pedagógico; estímulo à criticidade sobre a prática profissional; e possibilidade do desenvolvimento profissional da instituição mediante aspectos sociais e suas transformações.

Assim, a formação continuada não estaria ligada apenas a processos técnicos, de revisão didática ou conteudista, mas possibilitaria ao docente uma reflexão sobre sua prática, bem como uma inovação, reavaliação, construção de teorias.

A respeito da postura reflexiva do professor, Pimenta (2008) faz uma análise quanto ao uso do termo, diferenciando adjetivo de conceito. Conforme a autora, todo ser humano reflete (adjetivo), porém, apoiada nas ideias de Schön, o conceito de professor reflexivo sugere uma valorização da prática reflexiva que permita obter respostas a situações novas e 
de incerteza, sendo necessária uma reformulação nos currículos de formação que primeiro apresentam a ciência e depois a aplicação do conhecimento adquirido.

Libâneo (2008) apresenta o significado e os vários entendimentos associados à reflexividade na formação dos professores e ressalta a importância da superação do modelo da racionalidade técnica. Citando Zeichner, argumenta que a prática reflexiva confere ao professor um papel mais ativo na formulação de objetivos e seus meios de trabalho, compreendendo que o professor também é apto a contribuir para a construção de conhecimentos sobre o ensino.

Ghedin (2008) ainda nos mostra a importância da reflexão crítica que extrapola o espaço escolar e se insere no contexto social e político. Apresenta a dialética entre o fazer e o pensar, em que não se separam teoria e prática, que devem ser vistas "como dois lados de um mesmo objeto" (p. 133) para compreensão da construção do conhecimento. Assim, por meio do agir consciente, pautado pela inseparabilidade entre teoria e prática, tem-se a práxis, que conforme Silva (2011):

Só na unidade entre teoria e prática pode haver uma práxis transformadora da realidade, pois é a teoria que possibilita, de modo indissociável, o conhecimento da realidade e o estabelecimento de finalidades para sua transformação. No entanto, para produzir tal transformação não é suficiente a atividade teórica; é preciso atuar praticamente sobre a realidade. A prática, porém, não se basta a si mesma; se isto acontece, fica situada passivamente numa atitude acrítica em relação a ela mesma e perde usa capacidade transformadora, tornando-se aderência. (SILVA, 2011, p. 22)

\subsubsection{Profissão professor}

Imbernón (2011) nos apresenta a ideia de que para ter inovação nas instituições educacionais é necessário que haja uma redefinição da profissão docente. O professor precisa estar inserido no processo de inovação, participar ativa e criticamente dos processos de mudanças.

O professor ou a professora não deveria ser um técnico que desenvolve ou implementa inovações prescritas, mas deveria converter-se em um profissional que deve participar ativa e criticamente no verdadeiro processo de inovação e mudança, a partir de e em seu próprio contexto, em um processo dinâmico e flexível. (IMBERNÓN, 2011, p. 21) 
Em seu livro "Formação Docente e Profissional", Imbernón (2011) traz a ideia de que para ocorrer uma inovação educativa é necessário um novo conceito de profissionalização docente. $\mathrm{O}$ autor apresenta os conceitos de profissionalismo e profissionalização.

O termo profissionalismo está ligado às características específicas da profissão, ou seja, é "uma referência à organização do trabalho dentro do sistema educativo e à dinâmica externa do mercado de trabalho" (p. 26), para ser profissional é preciso obter uma variedade de características e conhecimentos específicos daquele trabalho a ser realizado, o que nos conecta a um grupo profissional, sujeito a um controle.

O segundo termo, profissionalização, é o processo socializador dessas características. Logo, se entendemos que a educação tem como um dos seus objetivos a formação crítica e emancipatória dos educandos, o profissional docente poderá, mediante sua prática, participar dessa formação, auxiliando o discente a desenvolver sua cidadania mediante problemas sociais.

Nesse sentindo, o profissional da educação tem como objetivo a formação para a transformação dos educandos, ou seja, a formação crítica e emancipatória. E seus conhecimentos estarão à disposição da sociedade para sua própria transformação.

\footnotetext{
A profissão docente comporta um conhecimento pedagógico específico, um compromisso ético e moral e a necessidade de dividir a responsabilidade com outros agentes sociais, já que exerce influência sobre outros seres humanos e, portanto, não pode nem deve ser uma profissão meramente técnica de "especialistas infalíveis" que transmitem unicamente conhecimentos acadêmicos. (IMBERNÓN, 2011, p. 30)
}

Sobre o conhecimento profissional do docente, Imbernón (2011) mostra que existe a união entre os conhecimentos pedagógicos e a participação social. Ele apresenta esse conhecimento como "o utilizado pelos profissionais da educação, que se construiu e reconstruiu constantemente durante a vida profissional do professor em sua relação com a teoria e a prática” (p. 31). Quando falamos sobre participação social, entendemos que o professor participa da vida social do aluno, enquanto formador, e também é formado durante sua prática docente.

Conforme Tardif (2012) os saberes que constituem a prática docente são: saberes sociais, saberes produzidos pelas ciências da educação, saberes pedagógicos, saberes disciplinares, saberes curriculares, saberes experienciais. Nas palavras do autor, o saber docente é "um saber plural, formado pelo amálgama, mais ou menos coerente, de saberes 
oriundos da formação profissional e de saberes disciplinares, curriculares e experienciais" (p. 36).

Partindo dessa noção, apresenta como os professores se relacionam com esses saberes. Por meio da abordagem histórica e cultural, o autor demonstra que alguns saberes são externos ao docente, uma vez que este não participa na escolha de sua formação, são escolhidos pelas universidades e outras entidades que estão ligadas à formação dos profissionais. São os saberes disciplinares, curriculares, científicos e pedagógicos, sobre os quais o autor aponta o risco da separação entre teoria e prática, reduzindo a prática pedagógica a uma profissão de transmissão de conteúdos e os profissionais a executores de tarefas (TARDIF, 2012).

O autor identifica também os saberes experienciais na formação docente, sobre os quais argumenta:

\footnotetext{
Ora, nossas pesquisas indicam que, para os professores, os saberes adquiridos através da experiência profissional constituem os fundamentos de sua competência. É a partir deles que os professores julgam sua formação anterior ou sua formação ao longo da carreira. É igualmente a partir deles que julgam a pertinência ou o realismo das reformas introduzidas nos programas ou nos métodos. Enfim, é a partir dos saberes experienciais que os professores concebem os modelos de excelência profissional dentro de sua profissão. (TARDIF, 2012, p. 48)
}

Entendemos desse modo que os saberes experienciais são constituídos, entre outros fatores, pela prática pedagógica e precisam ser levados em consideração na formação continuada dos docentes.

Tardif (2012) nos apresenta duas teses a serem levadas em consideração quando se trata de formação de professores: os docentes são sujeitos do conhecimento e possuem saberes específicos sobre sua prática e o seu trabalho cotidiano é um espaço de produção, transformação e mobilização de saberes próprios do seu ofício. Ou seja, a formação de professores não está alheia ao seu cotidiano escolar, o professor não é um objeto de estudo, mas ele é um protagonista da sua formação.

O professor possui saberes específicos, subjetivos, aliados a sua prática. Portanto, entendemos ser importante que a formação leve em consideração essa subjetividade. Para Tardif (2012), o professor não é um mero transmissor de conteúdos, ele é um ator no sentido restrito da palavra, ele protagoniza sua prática a partir dos seus próprios significados. Aliado 
a isto, o autor recomenda que as pesquisas sobre professores e sua formação considerem o professor como colaborador, seus interesses e suas necessidades e que eles se beneficiem da pesquisa/formação na possibilidade de torná-las práticas.

Entendemos, portanto, que a formação de professores pode ser feita a partir dos próprios professores, não deve ser algo imposto de maneira verticalizada, mas levando em consideração o professor como sujeito de um conhecimento que pode e deve auxiliar na sua própria formação. Os saberes docentes não podem ser apenas os saberes disciplinares/conteudistas, mas esses atrelados aos conhecimentos do cotidiano da sua profissão. Recomenda-se então, uma formação pautada no caráter reflexivo do dia-a-dia escolar, das suas realidades, de como os professores se comportam e buscam possíveis soluções para os dilemas e dificuldades enfrentados em seu cotidiano.

A formação continuada nos permite, entre outras coisas, redescobrir os objetivos da profissão docente, bem como, auxiliar sua profissionalização, pois trata-se da competência profissional, ou seja, perceber o professor como profissional que toma decisões que sustentam suas ações (ALMEIDA, 2005).

Nóvoa (2007) traz uma preocupação acerca da crise de identidade da profissão docente. Seus estudos mostram que as pesquisas feitas desde o final da década de 1980 sobre a profissão tendem a separar o eu profissional do eu pessoal, assim, os professores tiveram suas competências reduzidas à transmissão de conteúdos, passando a serem técnicos.

Por muitos anos as competências e características da profissão docente têm sido objeto de discussão. Costumeiramente são feitas perguntas como: o que caracteriza a profissão? Quais são as atribuições do professor? Quais conhecimentos formam o professor? Reconhecemos que todas essas perguntas são importantes, porém nossa intenção é pensar uma formação continuada que perceba os saberes experienciais dos professores e que eles fazem parte da profissionalização docente, pois entendemos que não há separação do pessoal com o profissional. 


\subsubsection{Formação continuada na escola}

Conforme Almeida (2005) existem múltiplas possibilidades para que a formação continuada ocorra, entre elas: escola, universidades, ambientes de educação a distância, museus e centros culturais, organizações não governamentais, sindicatos e outros órgãos sociais.

Temos a escola como um espaço privilegiado para a formação: profissional, acadêmica, formal, não formal, além de um espaço de socialização. A escola passa a ser vista como um agente de mudanças, superando a visão formalista, estática e funcionalista (IMBERNÓN, 2011). A formação dos sujeitos não restringe à formação acadêmica, mas é também a formação social e política. Os professores também fazem parte dessa formação.

Quando acontece dentro do contexto escolar, a formação continuada possibilita o caráter crítico-reflexivo, privilegia os saberes de cada professor, fortalece o Projeto Político Pedagógico, amplia a visão da escola como um espaço colaborativo, pois permite a troca de experiências e incentivo a reflexão.

Nóvoa (1992) defende o diálogo e as redes coletivas de trabalho entre os professores para a consolidação dos saberes da prática profissional, socialização e afirmação de valores próprios da formação docente. Ou seja, "práticas de formação que tomem como referência as dimensões coletivas contribuem para a emancipação profissional e para a consolidação de uma profissão que é autônoma na produção de seus saberes e dos seus valores” (p. 15).

Imbernón (2011) apresenta a ideia de "formação centrada na escola", não apenas como um local para reunir os professores, mas porque são muitos os benefícios observados, entre eles a melhoria na qualidade de ensino e aprendizagem, pois será um lugar de formação prioritária. A ideia é de que haja um novo enfoque que defina os conteúdos, as estratégias, os protagonistas e os propósitos da formação. Essa formação dentro do espaço escolar também possibilita a formação permanente dos professores, (IMBERNÓN, 2009), que também apresenta benefícios à prática colaborativa e à profissionalização docente.

A prática colaborativa, segundo o autor apresenta os seguintes pressupostos: a escola é um foco do processo de "ação-reflexão-ação"; reconstrução de uma cultura escolar como parte de um processo; criação de novos valores; a colaboração como filosofia de trabalho; processo de participação, envolvimento, apropriação e pertencimento; respeito e reconhecimento dos professores e redefinição da gestão escolar. (IMBERNÓN, 2011) 


\subsubsection{Produção de narrativas e formação docente}

Bueno (2002) nos mostra que os estudos com as histórias de vida de professores estão cada vez mais se destacando nas pesquisas sobre a formação continuada de professores. Ao citar autores como Nóvoa, Josso e Dominicié, a autora ressalta o caráter formativo do método, "uma vez que ao voltar-se para seu passado e reconstituir seu percurso de vida, o indivíduo exercita sua reflexão e é levado a uma tomada de decisão tanto no plano individual como no coletivo" (p. 23).

Nóvoa (2007) propõe a produção de narrativas como caminho para uma formação continuada que possibilite integrar o eu profissional com o eu pessoal, além de auxiliar a profissionalização docente.

O processo identitário passa também pela capacidade de exercermos com autonomia a nossa atividade, pelo sentimento de que controlamos o nosso trabalho. A maneira como cada um de nós ensina está diretamente dependente daquilo que somos como pessoa quando exercemos o ensino: "Será que a educação do educador não se deve fazer mais pelo conhecimento de si próprio do que pelo conhecimento da disciplina que ensina:" (Laborit, 1992, p. 55). Eis-nos de novo face à pessoa e ao profissional, ao ser e ao ensinar. Aqui estamos nós. Nós e a profissão. E as opções que cada um de nós tem de fazer como professor, as quais cruzam a nossa maneira de ser com a nossa maneira de ensinar e desvendam na nossa maneira de ensinar a nossa maneira de ser. É impossível separar o eu profissional do eu pessoal. (NÓVOA, 2007, p. 17)

Conforme Nóvoa (2006), a utilização das narrativas em pesquisas com professores tem sido mais recorrente a partir de 1970, ele destaca que sua utilização "têm dado origem a práticas e reflexões estimulantes, fertilizadas pelo cruzamento de várias disciplinas e pelo recurso a uma grande variedade de enquadramentos conceituais e metodológicos” (p. 19).

Ao tratar sobre questões teóricas e metodológicas dos métodos autobiográficos, Bueno (2002) apresenta os motivos para a crescente adesão ao método. Conforme a autora, da crescente insatisfação do uso com os métodos tradicionais nas pesquisas de cunho social surge a necessidade de se buscar outros métodos que considerem os aspectos subjetivos dos sujeitos e das relações sociais. Assim, o método autobiográfico tem como uma de suas características a reivindicação da subjetividade nas pesquisas como ideia articuladora e nuclear. 
Sobre o método biográfico, Ferrarotti (2010) faz uma reflexão quanto a sua utilização, nos apresentando dois aspectos: atribuição de um valor de conhecimento à subjetividade e o fato de estar situado além de uma metodologia quantitativa e experimental, sendo "subjetivo, qualitativo, alheio a todo o esquema hipótese verificação" (p. 37).

A respeito das especificidades desse método, o autor nos apresenta dois grupos de materiais utilizados:

Os materiais utilizados pelo método biográfico podem ser divididos em dois grandes grupos. De um lado, temos os materiais biográficos primários, isto é, as narrativas autobiográficas recolhidas diretamente por um investigador no quando de uma interação primária (face to face). Do outro, temos os materiais biográficos secundários, ou seja, os documentos biográficos de toda a espécie que não foram utilizados por um investigador no quadro de uma relação primária com as suas "personagens": correspondência, fotografias, narrativas e testemunhos escritos, documentos oficiais, processos verbais, recortes de jornal, etc. (FERRAROTTI, 2010, p. 43)

Assim, para o este autor, há uma necessidade de buscar valorizar os materiais primários e sua "subjetividade explosiva" (p. 43), em contraposição aos materiais secundários que possuem um caráter mais objetivo.

Acreditamos que as narrativas possam auxiliar essa reflexão do professor e, assim, abrir espaço para a transformação. Uma vez que escrevemos sobre nossa trajetória, podemos perceber os valores que carregamos conosco, o que nos formou professores e o que incentiva e motiva nossa prática. Quando pensamos em nossa formação e a escrevemos, podemos observar os períodos e as situações que interferiram na nossa escolha de sermos professores, nas decisões que tomamos em sala e na maneira como conduzimos nossa prática pedagógica. Apesar de ter influências externas, nossas ações são também motivadas por nossa trajetória de vida e por nossas experiências pessoais.

A noção de experiência é aqui tratada na perspectiva de Larrosa (2011). Para o autor, a experiência é particular de cada indivíduo e acontece na relação com um acontecimento, ou seja, com algo externo. Sugere três princípios para entendermos a experiência. O "princípio da reflexividade", segundo o qual a experiência é um movimento de ida, pois supõe um movimento de exteriorização, e de volta, pois supõe um movimento que afeta a pessoa. Ainda apresenta o "princípio da subjetividade", pois não há uma experiência que seja geral a todos, ela é própria de cada um, singular, particular. O "principio da transformação" apresenta o 
sujeito aberto a sua própria transformação. A partir disso, o autor nos fala sobre um sujeito da experiência.

Além disso, por meio das narrativas conseguimos perceber o outro na nossa formação. Ninguém se forma sozinho e ninguém é um ser pronto, estamos em constante transformação. Por meio da prática dos professores e entendendo que a subjetividade faz parte do processo formativo dos docentes é necessário abrir espaço para expressão desse professor e de como ele se relaciona com a EA para então, dentro de sua realidade, desenvolver a proposta de uma EA crítica e transformadora. Entendemos que a abertura para as concepções de EA que serão trabalhadas só será possível por meio da reflexão que o professor fará acerca de sua prática pedagógica. 


\title{
CAPÍTULO 3
}

\section{Entre tecidos, técnicas e feitios: \\ a pesquisa colaborativa como uma colcha de retalhos}

\author{
Não tente entender os nomes \\ Apliquê, matelassê, \\ Patchwork, patchcolagem \\ Apenas admire, é mais vantagem
}

(Walter da Mata)

A pesquisa qualitativa surgiu pra mim como um convite. As palavras da minha orientadora soam até hoje nos meus pensamentos: 'como tecer uma colcha de retalhos!?', a partir de então, este projeto foi pensado e construído como uma das artes mais belas: o artesanato.

De acordo com Minayo (2009), a pesquisa qualitativa é um instrumento que possibilita estudar o universo dos significados, valores, crenças, motivos e aspirações como parte da realidade social dos seres humanos e que não podem ser mensuráveis, mas possuem igual importância no contexto da pesquisa.

Conforme Bogdan e Biklen (1994) a pesquisa qualitativa possui cinco características, sendo elas: a) a fonte de pesquisa é o ambiente natural, ou seja, o pesquisador está inserido no local onde sua pesquisa será realizada; b) é descritiva, sendo possível analisar os dados contemplando sua riqueza nos detalhes e respeitando seu registro; c) possibilita um maior interesse do pesquisador no processo do desenvolvimento de seu trabalho, o objetivo da pesquisa não se limita apenas ao resultado final obtido, mas o processo que esta sendo constituída; d) permite a análise dos dados de forma indutiva, pois a medida que se recolhem os dados, as hipóteses são reformuladas ou formuladas, elas são construídas a partir do recebimento das informações; e) o significado tem uma importância vital da pesquisa, há uma preocupação com as considerações dos participantes da pesquisa.

A pesquisa colaborativa se apresentou como uma possibilidade de tecer a proposta de formação continuada em EA, pois ela se apoia no ponto de vista dos docentes acerca de suas práticas e reflexões quanto ao objeto de estudo proposto. De acordo com Desgagné (2007) ela apresenta três enunciados: a) supõe um processo de co-construção entre pesquisador e sujeito, b) apresenta dois registros, produção de conhecimento e prática docente e c) aproximação entre universidade e escola, sendo assim, a abordagem da pesquisa está ligada ao "saber exercer" do professor, do seu "saber profissional". 
A pesquisa colaborativa está ligada à prática profissional e a partir dela os professores atuam como co-construtores do conhecimento em relação ao objeto de estudo. Ela, então, pode auxiliar a formação docente, uma vez que a partir de reflexões sobre a prática, o profissional passa a corresponder ao seu desenvolvimento e/ou aperfeiçoamento profissional (DESGAGNÉ, 2007).

\footnotetext{
A pesquisa colaborativa se articula a projetos cujo interesse de investigação se baseia na compreensão que os docentes constroem, em interação com o pesquisador, acerca de um aspecto da sua prática profissional, em contexto real. Em consequência, o papel do pesquisador, no referido projeto colaborativo, se articula essencialmente em função de balizar e orientar a compreensão construída durante a investigação. (DESGAGNÉ, 2007, p.10)
}

Nesse sentido, cabe ao pesquisador reconhecer o professor como o ator principal da pesquisa, levando em consideração sua competência no exercício da profissão, suas reflexões sobre a prática e suas maneiras de enfrentar as situações cotidianas.

Visto que a pesquisa colaborativa pressupõe um processo de pesquisa e de formação, nesta investigação ela possuiu um papel fundamental, pois permitiu a produção de conhecimento sobre EA por meio de uma intervenção de formação continuada dos professores.

Tendo como exemplo a feitura de uma colcha de retalhos, iniciamos a confecção do projeto. Dentre as técnicas conhecidas escolhemos aquelas relacionadas a pesquisa qualitativa, a saber: 1) Observação participante; 2) Entrevista; 3) Ação de formação continuada em EA para professores de $4^{\circ}$ e $5^{\circ}$ ano.

\subsection{Observação participante}

Nosso primeiro contato com a escola ocorreu durante o mês de março com a observação participante. Para Minayo (2009) ela é "um processo pelo qual um pesquisador se coloca como observador de uma situação social, com finalidade de realizar uma investigação científica" (p. 70), apesar de seu objetivo ser a coleta de dados e a compreensão do contexto da pesquisa, o pesquisador participa da vida social, do cenário cultural e pode modificar o contexto.

Conforme Ludke e André (1986), a observação possibilita a coleta de dados e também um contato mais direto com o fenômeno observado. Como vantagens da observação, as 
autoras nos apresentam a experiência direta vivida pelo observador. Sendo assim, para estudar e compreender o fenômeno, o pesquisador pode recorrer a suas experiências e conhecimentos pessoais. Outra vantagem é que a partir da observação direta é possível chegar mais perto da "perspectiva dos sujeitos" (p. 26) sobre o mundo em que estão inseridos, sobre sua realidade.

Na pesquisa qualitativa, a aproximação do observador com o objeto pesquisado é vista como uma virtude e uma necessidade, o processo de observação permite ao pesquisador, uma abordagem mais livre, em que ele poderá alterar o seu roteiro a partir de situações antes não pensadas ou planejadas (MINAYO, 2009). O importante para essa observação é não ser vista apenas como alguém alheio à realidade escolar, mas estar próxima ao professor para que eles se sintam colaboradores diretos desta pesquisa e de sua formação.

Utilizamos um diário de campo da pesquisadora para registro das observações. A observação ocorreu nos espaços de coordenação coletiva (ocorridas às quartas-feiras), e assim podemos conhecer um pouco a dinâmica da escola, sua organização, além de ter maior interação com a comunidade escolar (professores, coordenadores, direção, servidores) e acompanhar algumas discussões quanto ao desenvolvimento dos projetos contidos no Projeto Político Pedagógico. A partir dessa observação entendemos que os dias disponíveis para a realização da ação de formação seriam as quintas feiras.

Dentro da modalidade de Anos Iniciais, optamos por trabalhar com as turmas de $4^{\circ} \mathrm{e}$ $5^{\circ}$ ano do período matutino, sendo seis professoras (três professoras de $4^{\circ}$ ano e três de $5^{\circ}$ ano), que prontamente se dispuseram em participar dessa formação. A princípio essa escolha foi aleatória, porém no decorrer do curso, percebemos que essa faixa etária pode apresentar maior maturidade e interação com as professoras na reflexão sobre as questões ambientais.

Os dados coletados durante as observações não foram objeto de análise, porém, foram fundamentais para o planejamento da ação de formação continuada, permitindo uma maior aproximação da realidade escolar nas discussões e reflexões quanto aos projetos que já estavam sendo desenvolvidos e os que seriam realizados no $3^{\circ}$ e $4^{\circ}$ bimestre. 


\subsection{Entrevista}

O segundo momento com a escola ocorreu durante as entrevistas. De acordo com Ludke e André (1986), a entrevista apresenta uma das principais técnicas de trabalho nas pesquisas sociais, pois tem um importante papel nas pesquisas relacionadas à atividade humana. Assim, a entrevista tem um caráter de interação entre o entrevistado e o entrevistador, permitindo ao entrevistador captar imediatamente a informação desejada. Outra característica é que por meio das correções, esclarecimentos e adaptações, a entrevista "ganha vida", podendo ser moldada durante o processo. Os cuidados pertinentes a esse instrumento estão ligados ao respeito pelo entrevistado; à capacidade de ouvir e estimular a entrevista pelo entrevistador e a partir de um roteiro bem estruturado, encaminhar a entrevista de forma gradual.

Minayo (2009) considera a entrevista como uma comunicação verbal e, no sentido mais restrito, uma coleta de informações sobre um determinado tema. As entrevistas podem ser "consideradas uma conversa com finalidades e se caracterizam pela sua forma de organização" (p. 64). A entrevista também é utilizada como instrumento nas pesquisas baseadas em narrativas. Ela oferece dados que possuem duas naturezas: a primeira relativa a dados que poderiam ser coletados por meio de outras fontes - senso, estatística, registros civis - e a segunda, ligada a dados que são obtidos de forma subjetiva, a partir do diálogo e de possíveis reflexões do próprio sujeito quanto a sua vivência. Para essa pesquisa, utilizamos dados da segunda natureza.

Para Bogdan e Biklen (1994):

Em investigação qualitativa, as entrevistas podem ser utilizadas de duas formas. Podem constituir a estratégia dominante para a recolha de dados ou podem ser utilizadas em conjunto com a observação participante, análise de documentos e outras técnicas. Em todas estas situações, a entrevista é utilizada para recolher dados descritivos na linguagem do próprio sujeito, permitindo ao investigador desenvolver intuitivamente uma ideia sobre a maneira como os sujeitos interpretam aspectos do mundo. (p. 134)

Neste sentido, há uma interação entre investigador e investigado. Para os autores, a entrevista na pesquisa qualitativa, mesmo quando há a utilização de um guia, permite uma amplitude de temas consideráveis e podem auxiliar o levantamento de tópicos que possibilitam moldar o seu conteúdo. Há, ainda, a possiblidade de o entrevistado guiar a 
entrevista, quando o entrevistador o deixar falar livremente sobre o tema pesquisado e, a partir de suas respostas, definir o conteúdo da entrevista e a condução do estudo.

A entrevista nos auxiliou a conhecer a perspectiva dos docentes sobre EA e formação continuada. Foram realizadas entre 07 e 28 de abril de 2016 com as professoras que se mostraram interessadas em participar da ação de formação continuada e assinaram um termo de consentimento livre e esclarecido - TLCE (Apêndice 1). Foram individuais, semiestruturadas e tiveram quatro perguntas bases como orientação:

1. Com base na sua experiência profissional, qual o papel da formação continuada na prática docente?

2. Em sua trajetória docente, o que a EA significa pra você?

3. O que você acredita ser a formação de professores em EA?

4. Quais as facilidades e as dificuldades que você encontra para desenvolver atividades de EA na escola?

O registro das entrevistas foi feito através de gravador de áudio e, quando necessário, foram feitas as observações nos diários de campo. Conforme conversado com as professoras, e por opção do grupo, foram utilizados nomes fictícios para representar as falas e os escritos das professoras participantes.

\subsection{Ação de formação continuada: a escola como espaço para a formação}

Esta experiência de formação continuada ocorreu dentro do espaço escolar e foi construída a partir das entrevistas, pois assim entendemos que há uma maior aproximação à realidade da escola e às necessidades dos professores, facilitando a abordagem colaborativa pretendida neste trabalho.

Atualmente a escola atende as modalidades de ensino: Educação Infantil, Anos Iniciais e Ensino Especial, recebendo alunos da própria comunidade local e alguns que moram em Santo Antônio do Descoberto, munícipio de Goiás que se localiza no entorno do DF. Uma das suas principais características é o trabalho coletivo no Projeto Político Pedagógico, voltado para elaboração de projetos interdisciplinares, além de promover espaços para formação continuada nas reuniões pedagógicas.

A elaboração inicial do plano de curso apresentou como objetivo auxiliar as professoras a refletirem sobre a prática docente, em especial, no que diz respeito à EA, contribuindo para sua profissionalização e formação crítica dos educandos. A ação se 
desenvolveu em sete encontros presenciais, cada um de $3 \mathrm{~h} / \mathrm{aula}$, e atividades em ambiente virtual, além da escrita em diário de bordo, totalizando 30h/aula.

Os encontros foram marcados por constantes diálogos e reflexões. Entendemos que por meio da prática das professoras e considerando que a subjetividade compõe o objeto de estudo (BUENO, 2002) desta pesquisa, era fundamental abrir espaço para expressão dessas docentes e de como elas se relacionavam com a EA para então, dentro de sua realidade, desenvolver uma proposta de EA crítica e transformadora.

\subsubsection{Tecendo a colcha de retalhos: Descrição dos Encontros}

Entendemos que seria interessante começarmos nossa conversa a partir das reflexões acerca do que é EA, sendo assim, nosso primeiro encontro teve como objetivo iniciar uma reflexão a partir das seguintes perguntas:

1. O que é EA?

2. Porque e para quê trabalhar a EA na escola?

3. Qual a visão que tenho sobre meio ambiente?

As reflexões foram feitas em três momentos distintos: individual, em duplas (com a ausência de uma professora, dividimos em grupos, um trio e uma dupla) e coletivamente. $\mathrm{O}$ registro do primeiro momento ocorreu no diário de bordo, para o segundo momento as professoras registraram em fichas para montagem de um painel e no terceiro momento a exposição das ideias foi oralmente, fazendo uma roda de conversa.

Como atividade complementar, e já introduzindo o tema para o nosso segundo encontro, solicitamos a leitura de três documentos oficiais que tratam dos objetivos e princípios da EA, são eles: Declaração de Tbilisi, Política Nacional de Educação Ambiental (Lei 9795/99) e Tratado de Educação Ambiental para sociedades sustentáveis e responsabilidade global.

Assim, no nosso segundo encontro, iniciamos uma conversa sobre o surgimento da EA, seu contexto histórico e as grandes conferências realizadas. Foi exibido um vídeo com animação sobre o Tratado de EA para sociedades sustentáveis e responsabilidade global, elaborado por Michele Sato. Novamente a turma foi dividida em grupos para análise e discussão dos documentos sugeridos (um trio e uma dupla) sobre sua prática na escola: esses objetivos e princípios são possíveis de serem aplicados dentro do contexto escolar? Eles já estão presentes dentro da minha prática? O registro ocorreu nos diários de bordo e em fichas para serem colocadas no painel. Como tarefa complementar, solicitamos que as professoras 
assistissem aos filmes WallE $^{1}$ e Como treinar seu dragão ${ }^{2}$ antes do próximo encontro. Com objetivo de iniciarmos uma reflexão sobre as relações dos seres humanos entre si e com a natureza, optamos por trabalhar com filmes de diferentes gêneros: documentário, ficção e animação. $\mathrm{O}$ intuito foi o de integrar conhecimentos técnicos, criatividade e imaginação, contribuindo assim com a formação dos docentes e abrindo possibilidades para o desenvolvimento da sua prática pedagógica.

Iniciamos nosso terceiro encontro assistindo ao documentário A História das Coisas ${ }^{3}$. O objetivo desse encontro foi promover uma reflexão sobre a 'Crise ambiental' a partir das relações entre humanos na sociedade contemporânea e dos humanos com a natureza. As discussões foram feitas com base também nos dois filmes, WallE e Como treinar seu dragão, possibilitando uma maior compreensão das relações existentes a partir dos seguintes questionamentos: Como eu percebo a relação do ser humano com a natureza? Como ela está traduzida nos filmes? Essa tradução é compatível com a realidade? Nos filmes existe uma relação entre os seres humanos? Como ela está estabelecida?

Como complemento às atividades, sugerimos que fosse feita uma reflexão individual, com registro no diário de bordo, sobre os filmes utilizando duas perguntas como base:

1. E eu com isso?

2. E eu nisso?

Para o nosso quarto encontro, havíamos pensado em trabalhar os conceitos e percepções sobre o Meio Ambiente, mas optamos por fazer uma pausa para reavaliarmos nossos encontros e apresentamos o andamento da pesquisa até o momento, que resultou no projeto de qualificação do mestrado.

As professoras se sentiram contempladas com os temas abordados no plano de ação, pois já trabalhavam com os alunos algumas temáticas voltadas à EA. Solicitaram, portanto, algumas ideias sobre vídeos, músicas, filmes que podem ser trabalhados com os alunos. A partir das sugestões dadas pelas professoras, durante o encontro pensamos em discutir um pouco mais sobre a prática pedagógica e levar como sugestão a elaboração de um plano de

\footnotetext{
${ }^{1}$ MORRIS, J. Wall E [filme-vídeo]. Dirigido por Andrew Stanton. EUA. 2008. Animação. 98 min.

${ }^{2}$ ARNOLD,B. How to train your dragon (original) [filme-vídeo]. Dirigido por Cris Sandres e Dean DeBlois. EUA. 2010. Animação. $98 \mathrm{mi}$.

${ }^{3}$ FOX, L. Story of stuff [filme-víde]. Produzido por Free Range Studios. Versao brasileira Comunidade de Permacultra. A história das coisas. Dublado por Gavi New Track, dirigido por Flávio Gavi. Disponível em < https://www.youtube.com/watch?v=7qFiGMSnNjw> Acesso em: 13 abr. 2016.
} 
ação voltado aos projetos já estabelecidos para serem desenvolvidos nos $3^{\circ}$ e $4^{\circ}$ bimestres do ano letivo.

Retomamos os conceitos estudados nos encontros anteriores e, mais uma vez, discutimos sobre a crise ambiental, entendendo a importância da EA crítica.

No quinto encontro, tivemos a oportunidade de refletir sobre o Meio Ambiente a partir da observação de diversas imagens que retratam o ambiente urbano, rural, conservado, tendo como base as perguntas: o homem faz parte do MA? Como ele se relaciona com o MA? Para auxiliar e ampliar nosso entendimento sobre MA, utilizamos as visões de natureza apresentadas por Carvalho (2004), discutindo as construções históricas sobre as relações Humanos-Natureza. O primeiro registro foi feito coletivamente nas fichas para compor o painel, respondendo à pergunta: Qual visão temos sobre MA? No segundo momento do nosso encontro, solicitamos o registro no diário de bordo, individualmente, sobre o que havíamos conversado no coletivo.

Como atividade complementar, foi solicitado que as professoras fizessem uma reflexão no diário de bordo sobre experiências em projetos de EA vivenciados por elas, tendo como base as seguintes perguntas:

1. Eu já trabalhei com projetos de EA?

2. Como eles foram desenvolvidos?

3. Como eu me senti durante a realização?

4. O que percebo ser o ambiente dentro dos projetos que desenvolvi?

No início do sexto encontro, compartilhamos as experiências vivenciadas em projetos de EA, bem como ideias, apontamentos e reflexões sobre o que estudamos até o momento. Após esse primeiro momento, utilizando as fichas construídas coletivamente nos três primeiros encontros, retomamos as discussões sobre os objetivos da Educação e EA crítica na formação do sujeito, valorizando a formação do sujeito ecológico e do educador ambiental. Refletimos sobre atitude, comportamento e ação política como elementos para pensar a formação ecológica, apresentados por Carvalho (2004), e a EA nos projetos transversais, trazida por Segura (2007).

Como proposta para construção coletiva da inserção da EA crítica nos projetos já existentes da escola, solicitamos às professoras que elaborassem um plano de ação utilizando a EA como eixo transversal nos projetos do $3^{\circ}$ e $4^{\circ}$ bimestre. A proposta para atividade complementar foi baseada na sugestão de atividade desenvolvida por Carvalho (2004) sobre o 
papel do professor na formação de valores, atitudes e comportamentos dos alunos, as reflexões foram registradas no diário de bordo.

O sétimo encontro foi marcado por dois momentos distintos de compartilhamento. No primeiro momento as professoras conversaram sobre suas experiências a partir das perguntas:

1. Você, em sua trajetória como aluno(a), identifica situações em que se sentiu fortemente identificado(a) com um professor e seus ideais?

2. Lembra outras situações em que, a despeito das expectativas, privilegiou caminhos, decisões e intuições diferentes das que você acreditava serem as esperadas?

3. Enquanto educador(a), como você se sente a respeito de seus alunos? Quais são suas expectativas em relação a eles e suas futuras escolhas?

No segundo momento as professoras apresentaram, coletivamente, o plano de ação desenvolvido por elas para trabalhar a EA nos projetos já existentes da escola. Finalizamos o encontro realizando a avaliação sobre o curso com registro feito no diário de bordo.

Nosso último encontro com as professoras ocorreu no dia 20 de dezembro de 2016. Esse encontro teve dois objetivos principais, atualizar as professoras sobre o desenvolvimento do nosso trabalho e ouvir delas o que significou o curso no decorrer do ano letivo e se foi possível desenvolver as atividades propostas no plano de ação que haviam desenvolvido de acordo com os projetos já existentes na escola.

\subsection{Análise dos resultados produzidos}

Ao montarmos uma colcha de retalhos, após a separação dos tecidos, da escolha das cores, linhas e formato para a peça, precisamos escolher uma técnica para então costurarmos nossos retalhos. Assim, para o nosso projeto, escolhemos utilizar a análise de conteúdo como técnica para conectar e analisar as peças produzidas: os diálogos das entrevistas e as discussões realizadas durante a ação de formação.

Conforme Franco (2012), a análise de conteúdo tem como ponto de partida a mensagem, sendo ela verbal, gestual, silenciosa, figurativa, documental ou diretamente provocada, considerando que há uma relação entre a emissão da mensagem com as condições contextuais de seus produtores. Assim, é tida como um procedimento de pesquisa situada num campo mais amplo da teoria da comunicação, permitindo ao pesquisador fazer inferências sobre qualquer um dos elementos da comunicação (FRANCO, 2012). 
Minayo (2009) ao fazer algumas considerações sobre a análise de conteúdo nos indica que o foco não está na exploração do conjunto quantitativo de opinião dos participantes, mas sim na abordagem qualitativa, nas igualdades e diferenças dos elementos de comunicação encontrados no grupo. Apresenta, também, as diferenças conceituais quanto à descrição, análise e interpretação, ressaltando o uso da palavra interpretação como busca de sentidos as falas e ações para compreender o que estão além do falado e do escrito.

Ao analisarmos os dados produzidos durante as entrevistas e os encontros, transcritos na íntegra, e também na tentativa de responder nossas questões de pesquisa, dividimos as informações em dois blocos temáticos: Educação Ambiental e Formação Continuada de Professores.

A análise da EA foi desenvolvida a partir da compreensão das dimensões conceitual, formativa e metodológica presentes nas questões de pesquisa. Sobre a conceitual buscamos identificar o entendimento das professoras sobre EA a partir das concepções sobre as relações dos seres humanos com a Natureza, apresentadas por Tozzoni-Reis (2004).

A dimensão metodológica foi utilizada como possibilidade de entendimento sobre a prática pedagógica desenvolvida pelas professoras relacionadas à EA nos projetos e currículo escolar. A dimensão formativa auxiliou na reflexão sobre como entendem a relação entre EA e a formação dos sujeitos.

Essas dimensões resultaram em três eixos de análise: concepções sobre EA, EA e a prática pedagógica; EA e a formação dos sujeitos. Para cada eixo foram criadas categorias $a$ priori, conforme apresentado no Quadro 1.

Quadro 1: Eixos de análise e categorias a priori

\begin{tabular}{|c|r|}
\hline Eixos de análise & Categorias a priori \\
\hline Concepções sobre EA & a) Concepção naturalizada \\
& b) Concepção cognoscitiva \\
c) Concepção histórico-social \\
\hline EA e prática pedagógica & a) Ênfase comportamental \\
& b) Ênfase crítica \\
\hline EA e formação dos sujeitos & a) Conscientização como repasse de informações \\
& b) Conscientização como processo reflexivo \\
\hline
\end{tabular}


Com o intuito de responder as questões de pesquisa referentes à formação continuada de professores, os dados foram produzidos a partir da leitura exaustiva da transcrição das entrevistas e dos encontros, resultando em três categorias emergentes.

a) Formação como capacitação ou instrumentalização

b) Formação como atualização ou aquisição de informação

c) Formação como relação entre teoria e prática docente

Com o objetivo de estudar o potencial reflexivo e formativo das narrativas autobiográficas durante a ação de formação, buscamos valorizar as reflexões e o caráter subjetivo das narrativas, por isso, optamos por não fazer o uso de análises com categorias. Ressaltamos, portanto, a importância do uso desse método no processo de formação continuada proporcionando momentos de reflexão individual e coletiva, dando escuta a voz ao professor e a possibilidade de ser protagonista da sua própria formação.

Os diários de bordo foram entregues às professoras no primeiro encontro que, durante todo o processo, foram motivadas a escrever e refletir sobre sua prática e sua formação docente. As atividades com o diário de bordo foram contabilizadas como horas complementares e durante dois encontros (o $6^{\circ}$ e o $7^{\circ}$ ) as professoras foram estimuladas a compartilhar suas escritas com as colegas.

Uma das características da pesquisa colaborativa é a possibilidade de, mesmo sendo pesquisadora, participar do processo de formação. Durante a feitura dessa ação formativa, bem como durante o mestrado, eu também fui formada. Por isso, sobre o potencial das narrativas no processo de formação continuada, incluímos parte da minha própria narrativa, nelas apresento minhas reflexões sobre o processo da minha formação enquanto professora da rede pública de ensino e aluna do mestrado. 


\title{
CAPÍtUlO 4
}

\section{Uma colcha de retalhos: possíveis formatos}

\author{
A artesã brilha reunindo cores \\ Dom divino, Criar e embelezar, \\ Pois Criador Mor é o Eterno \\ Tecendo a terra, tapete multicores \\ (Walter da Mata)
}

\subsection{Educação Ambiental}

Conforme mencionado, na tentativa de responder as nossas questões de pesquisa relacionadas a EA, dividimos a análise em três eixos a saber: Concepções sobre EA; EA na prática pedagógica; EA e formação dos sujeitos.

\subsubsection{Concepções sobre EA}

As análises das falas das professoras durante as entrevistas e os encontros nos indicam as opiniões que possuem sobre EA. Utilizando as concepções das relações entre Humanos e Natureza apresentadas por Tozzoni-Reis (2004), conforme mencionado em nosso referencial teórico, dividiremos em três categorias, a saber: Concepção naturalizada, concepção cognoscitiva e concepção histórico-social.

\section{a) Concepção naturalizada}

Em linhas gerais, a concepção do sujeito natural apresentada por Tozzoni-Reis (2004) remete à ideia do ser humano resgatar seu lugar na natureza e assim submeter-se "às 'leis naturais', como os outros seres vivos, para garantir o equilíbrio harmônico da natureza" (p. 28). Assim, esse sujeito, que não pertence à natureza, deve ter boas atitudes como possível garantia de evitar sua destruição.

Ao serem questionadas sobre o que entendem por EA, podemos perceber, nas respostas, uma preocupação quanto à conservação ${ }^{4}$ dos recursos naturais e que nossas atitudes/ações poderão garantir um futuro melhor ou a destruição da natureza.

\footnotetext{
${ }^{4}$ De acordo com o Sistema Nacional de Unidades de Conservação, Lei 9985/2000, “conservação da natureza: o manejo do uso humano da natureza, compreendendo a preservação, a manutenção, a utilização sustentável, a restauração e a recuperação do ambiente natural, para que possa produzir o maior benefício, em bases sustentáveis, às atuais gerações, mantendo seu potencial de satisfazer as necessidades e aspirações das gerações futuras, e garantindo a sobrevivência dos seres vivos em geral".
} 
Eu acho que são atitudes que a gente deve trabalhar com o aluno pra preservação do ambiente, o meio que a gente vive, pra gente viver melhor... eu acredito que seja isso né, preparar e educar pra que o mundo possa ser melhor. O hoje, o mundo de amanhã, porque se a gente não tomar certas atitudes hoje, o mundo realmente vai está difícil. (Carla, entrevista, 07/04/2016)

A palavra preservação citada pela professora sugere uma natureza vista como algo a se cuidar, distanciada das relações humanas. As atitudes que o ser humano têm em relação à ela pode trazer uma garantia de um futuro melhor ou a destruição e prejuízo no futuro.

Essa leitura sobre EA tem como base a visão da natureza como boa e bela, que surge no século XVIII, após a Revolução Industrial. A partir das experiências vivenciadas pela sociedade em um ambiente hostil, surgem novas sensibilidades de sentimentos estéticos e morais incentivando a valorização da natureza ainda não explorada pelo homem (CARVALHO, 2004). Se a natureza intocada é boa e bela, deve ser preservada e o homem, por sua vez, atua sobre ela como perturbador e, por isso, deve repensar suas atitudes e ações, nesse sentido, podemos inferir que para a professora, a EA pode auxiliar na construção de novas atitudes como possível garantia de um mundo melhor.

Ainda sobre esse pensamento:

A dificuldade na escola é o espaço porque você não tem como ensinar a criança a preservar o ambiente sem ter o ambiente preservado né, como a gente vai montar uma horta se não tem espaço? Plantar uma árvore se não tem espaço e nem pode? Então fica difícil você ensinar na prática pra eles o que é preservar. Fica difícil. (Marta, entrevista 27/04/2016)

A professora Marta apresenta a falta de um lugar preservado como dificuldade em trabalhar a EA, para então mostrar o que seria essa preservação. Consideramos o termo apresentado no sentido de conservação, pois em seu argumento ela remete à ideia de montar uma horta, ou seja, de manejar o espaço.

Outro entendimento sobre EA presente nos relatos nos remete à ideia de uma natureza "naturalizada", de ordem biológica, sem a interação social, e que deve ser protegida da intervenção humana (CARVALHO, 2004). Vejamos o relato da professora Laura: 
natureza tá ali, ela está quietinha, mas se a gente for lá e mexer com ela pro mal, ela vai responder, a natureza vai responder e responde da pior maneira, por isso que tem erosão, enchentes, tem as questões dos bueiros, né, então assim, quando a gente vai falar de lixo, da coleta de lixo, sobre queimadas, desmatamentos, entendeu! Então eu vejo mais pra essa parte mesmo do meio ambiente, preservação e conservação do MA. (Laura, entrevista, 07/04/2016)

A fala apresentada também nos remete à ideia de que o ser humano não pertence à natureza, pois conforme a professora, "a natureza tá ali, ela está quietinha" e que o homem, ao mexer com ela, pode provocar uma reação boa ou má. Os impactos "negativos" causados pela natureza são consequências da ação humana sobre ela, como no trecho a seguir:

Eu falo pra eles, esses desastres, porque eles perguntam: ah professora, isso aconteceu em tal lugar! Isso tudo é reflexo do homem, né! (Letícia, $1^{\circ}$ encontro, 28/04/2016)

Podemos inferir a partir dos depoimentos que, dentro dessa visão, a prática da EA está ligada ao ensino de boas atitudes e comportamentos, em uma abordagem mais individualista e não coletiva, como se a soma de boas ações de vários indivíduos pudesse causar um impacto positivo na natureza evitando assim, a sua destruição, porém não discute as implicações dessas ações, nem as causas relacionadas ao modelo de desenvolvimento socioeconômico atual.

Sobre esse pensamento, podemos ainda considerar uma visão que se distancia de uma abordagem complexa e que desconsidera a ciclicidade dos fenômenos naturais. Quanto à complexidade, a EA pode levar em consideração as diferentes relações e inter-relações existentes entre os sistemas naturais e os sistemas sociais. O ser humano é considerado como pertencente a essa natureza e interage com ela.

Conforme a fala da professora Laura, ao mencionar a erosão, o desmatamento e as enchentes não há uma discussão quanto a outros problemas sociais que interagem com esses fenômenos, não havendo, portanto, uma reflexão sobre suas causas.

O discurso da professora Laura ainda pode estar relacionado à ideia de linearidade entre causa e efeito no que se refere aos fenômenos naturais. Ao contar a história para os alunos, mencionando que a natureza está quietinha, mas com a ação do homem ela pode responder, há uma simplificação das relações existentes na natureza. Morin (2003) menciona o reducionismo como método de conhecimento até a metade do século $\mathrm{XX}$ - em que o todo é 
reduzido a um conhecimento das partes, além de considerar o determinismo como conceito principal.

Assim, ao pensarmos a partir de uma abordagem reducionista, retiramos as ligações e intercomunicações do objeto com seu ambiente destruindo as relações das partes com o todo. Para Morin (2003), o conhecimento pode ser apresentado em partes, porém deve ser feita referência com o contexto em que está inserido. Ao mencionar os problemas causados pela ação do homem, a professora Laura aparenta não considerar as relações sistêmicas e complexas que existem entre os elementos da natureza. Para Morin (2003) esse pensamento "destrói a complexidade do mundo em fragmentos distintos, fraciona os problemas, separa o que está unido" (p. 71).

Nesse sentido, ressaltamos a importância de um ensino de EA que considere o pensamento complexo, a ideia de conexão entre as unidades de um sistema, o que resulta numa rede complexa de causas e efeitos, "um pensamento que busca distinguir (mas não separar), ao mesmo tempo que busca reunir" (MORIN, 2003, p. 71).

\section{b) Concepção cognoscitiva}

Esta categoria dialoga com a noção de sujeito cognoscente, apresentada por TozzoniReis (2004), que nos indica que a aquisição dos conhecimentos científicos são suficientes para a garantia de um bom relacionamento e conservação da natureza. Para esse sujeito há uma necessidade de um conhecimento mais racional que o auxilie a compreender a natureza. Como apresentado pela autora, a solução para os problemas ambientais estaria na educação e no desenvolvimento da tecnologia.

Sobre sua prática com EA, a professora Marta, comenta:

A conscientização da conservação da água, de como usar a água. Aí a gente estuda, explica pra eles como escovar os dentes, como preservar, como economizar, como não gastar pra preservar a natureza, porque a água vai faltar, para eles terem a consciência que a humanidade está caminhando pra falta da água. (Marta, entrevista, 27/04/2016)

Ao trabalhar com a temática da água, a professora destaca que "conscientiza" os alunos quanto à conservação, explicando sobre como escovar os dentes, como preservar e economizar água, aqui compreendida como recurso, e alertando sobre sua possível falta. Podemos inferir que há uma compreensão de que ao acessarem informação sobre como 
utilizar a água e serem alertados sobre sua possível falta na natureza, os alunos estarão conscientes quanto à conservação desse recurso, o que sugere que conscientização está relacionada a acesso à informação.

Ainda sobre o valor do conhecimento, a professora nos mostra,

\footnotetext{
Eu acho que se fosse mais esclarecido pros alunos do fundamental e ensino médio, acho que eles teriam mais preocupação, mais vontade de aprender, mais vontade de conhecer o que é EA. Porque os alunos passam... a gente fala, mas não é obrigação pra eles, se tivesse assim, um maior conhecimento, eles seriam mais educados, o ser humano se educaria melhor. (Laura, $7^{\circ}$ encontro, 28/06/2016)
}

Dentro desta visão, a aquisição e a correta transmissão dos conteúdos técnicos e científicos implicam uma garantia de bom relacionamento dos seres humanos com a natureza, reestabelecendo o equilíbrio entre os dois polos da relação.

As observações quanto a este primeiro pensamento reforçam a ideia da racionalidade científica, que prioriza o conhecimento cognitivo instrumental, citado por Santos (2001). Nessa concepção predomina um caráter salvacionista das ciências e da tecnologia, está presente uma preocupação de ensinar os conhecimentos científicos e tecnológicos como possibilidade de transformação das atitudes/ações.

Sobre esse pensamento, Grün (1996) nos apresenta as construções históricas e culturais da racionalidade humana, mostrando as rupturas das relações entre os humanos e a natureza no século XVI que levaram à ética antropocêntrica. A natureza passou a ser algo distante, sem vida e mecânica, a razão humana passou a ser o centro do universo e a natureza foi objetificada, o que é chamado pelo autor de "paradigma mecanicista". Com isso, a natureza foi subjugada aos parâmetros da ciência moderna e só podemos ter uma relação com ela através do conhecimento científico.

\footnotetext{
A questão de que acha que vou jogar lixo na rua porque é rua, mas não pensa na questão de que aquilo até vai demorar pra degradar, vai sujar, vai levar anos e anos, vai prejudicar. Eles não têm essa consciência. E isso eu percebi esse ano com os alunos do $5^{\circ}$ ano, aquela sujeirada e eles não entendem isso, aí eu comecei a conversar com eles: sabe que acontece isso, aquilo... Tudo o que a gente faz tem consequência. (Sara, entrevista, 07/04/2016)
} 
Observamos que ao trabalhar a questão do lixo em sala de aula, a professora faz menção à importância de ensinar sobre o tempo de degradação dos materiais e os prejuízos que podem causar ao meio como garantia de uma conscientização do aluno, apostando que com isso ele não voltaria a jogar lixo no chão. Inferimos, portanto, que aqui a prática pedagógica estaria ligada à transmissão desse conhecimento para que os alunos obtenham um bom comportamento, pois sabendo do tempo de degradação dos materiais, então o correto seria jogar o lixo nos lugares destinados a ele.

Notamos ainda, uma possível simplificação da relação causa-efeito no que se refere à questão dos resíduos sólidos, pois não há indícios de uma reflexão quanto à origem do material descartado; à produção excessiva ligada ao consumo e o descarte, sobre o destino final após ser depositado na lixeira, sequer sobre questões sociais relacionadas a consumo e reciclagem.

Entendemos que os conhecimentos técnicos científicos construídos ao longo dos anos são importantes, porém reduzi-los à transmissão de informação não gera as mudanças pretendidas pela EA crítica. A partir desses conhecimentos cabe ao docente a reflexão quanto às questões complexas que estão inseridas nas temáticas sobre EA.

\section{c) Concepção histórico-social}

Vejamos os relatos das professoras Sandra e Letícia:

conscientizar esses alunos que o mundo não é só aqui onde a gente vive, a nossa casa e a nossa escola, é muito maior que isso, que as ações que a gente tem, tem impacto social e ambiental na nossa vida e na do outro... o que eu fizer vai impactar na vida do outro também. (Sandra, entrevista, 07/04/2016)

eles se reconhecerem como sujeitos ativos no meio em que eles vivem, ativos tanto negativos quanto positivos, que nem a questão do desperdício, como não desperdiçar? o que eu posso fazer pra não prejudicar a outra pessoa lá na frente? [...] o que que eu posso fazer dentro da minha casa, dentro da minha comunidade? (Sandra, $2^{\circ}$ encontro, 05/05/2016)

Hoje eu tenho essa preocupação, de passar pros alunos do lixo que é produzido, pra onde vai, porque eles não tem isso, né!? Hoje a gente tem uma conscientização maior, pra eles entenderem pra onde vai, de onde vem, o que é feito com tudo isso! (Letícia, $3^{\circ}$ encontro, 12/05/2016) 
Percebemos nas falas das professoras uma ideia sobre as relações existentes entre os seres humanos com a natureza e entre si. A professora Sandra, ao falar sobre o que seria a EA para ela, menciona a conscientização dos alunos sobre o meio ambiente e sobre os impactos que as ações podem causar na vida de outras pessoas. Na segunda fala, da mesma professora, há uma preocupação quanto ao que se pode fazer para que não haja prejuízo pra outras pessoas.

A professora Letícia, ao mencionar sobre o lixo, mostra se preocupar em construir com os alunos um entendimento sobre a produção e o destino final desse lixo. As falas das professoras nos remetem à ideia de que há uma interação dos humanos com o ambiente, de modo que alguns aspectos sociais são mencionados, como por exemplo, a preocupação com os impactos causados a outras pessoas.

Mesmo que de uma forma discreta, há indícios de uma reflexão sobre um processo complexo das relações estabelecidas. Mas será que isso nos indica uma percepção mais crítica quanto a essas relações?

Sobre o sujeito social, citado por Tozzoni-Reis (2004), há que considerar não apenas a relação ser humano-natureza, mas um entendimento histórico e social dessa relação que, portanto, é entendida como sociedade-natureza. Assim, nessa concepção, os aspectos históricos e sociais devem ser considerados. A visão das professoras citadas, mesmo que tímidas, podem indicar o reconhecimento dessas relações.

Podemos ainda refletir sobre outro aspecto, a questão da responsabilidade com o próximo. A professora Sandra faz referência sobre a possibilidade das ações de um indivíduo afetarem social e ambientalmente a vida de outras pessoas. Sobre essa visão, Carvalho (2004) nos apresenta uma EA crítica que "deveria fornecer os elementos para a formação de um sujeito capaz tanto de identificar a dimensão conflituosa das relações sociais que se expressam em torno da questão ambiental quanto de posicionar-se diante desta" (p. 163).

A EA crítica pode proporcionar uma reflexão quanto aos valores presentes em nossa sociedade. Nesse sentido, Leff (2013) nos apresenta a racionalidade ambiental como possibilidade de uma reforma de pensamento e a partir do pensamento coletivo, buscar novos valores e atitudes.

Ainda que de forma incipiente e tímida, a preocupação das professoras nas discussões sobre o desperdício e o lixo podem ser um indício da inserção de questões históricas e sociais, bem como a busca por uma nova racionalidade como princípios das relações socioambientais. 


\subsubsection{EA e prática pedagógica}

Durante a entrevista e a ação de formação perguntamos às professoras sobre as possíveis experiências em projetos ou práticas pedagógicas em EA. Observamos que não havia respostas concretas sobre os projetos, mas ao falar em EA foram associados temas ligados à reciclagem, conservação e preservação da água, energia eólica (construção de maquete e extração de energia a partir de fontes alternativas), poluição da água, do ar e do solo, e alimentação saudável (construção de uma composteira).

Nosso objetivo a partir dessa análise foi buscar identificar como as professoras relacionam o currículo e projetos da escola com as questões ambientais. Não temos o intuito de analisar o currículo e o Projeto Político Pedagógico minuciosamente, mas conforme as falas das professoras, entender como a EA pode ser traduzida na prática pedagógica.

Podemos inferir que as percepções que as professoras têm a respeito da EA, citadas no primeiro eixo aqui estudada, indicam uma possível linha de atuação.

Carvalho (2004) nos lembra que, no caso da EA, surge uma demanda social por questões ambientais e essas repercutem na área da educação, assim, podemos, enquanto educadores, ter a sensibilidade e abertura para o diálogo com os movimentos sociais, percebendo o necessário trabalho interdisciplinar e buscando superar modelos atuais e históricos da nossa prática docente. Nosso intuito é perceber quais os sentidos atribuídos à EA nos projetos desenvolvidos ou em desenvolvimento pelas professoras.

Foi possível identificar duas categorias, a saber: ênfase comportamental e ênfase crítica.

\section{a) Ênfase comportamental}

Sobre a EA nas suas práticas pedagógicas, a professora Laura apresenta:

Eu falo pros meus alunos, se você faz algo ruim pra natureza, meio ambiente, ela vai te responder da pior maneira, eu linkei com eles a questão do deslizamento de terra, falei um pouquinho também sobe o efeito estufa, ai você vai linkando, por que depende da nossa atitude, por que se você tiver uma atitude boa, o ambiente vai ser preservado, se a gente tiver uma atitude ruim ele vai ser impactado, ele vai voltar! (Laura, $1^{\circ}$ encontro, 28/04/2016) 
Ao falar sobre o projeto desenvolvido com os alunos no $1^{\circ}$ bimestre, a professora Laura mostra aos alunos a importância de não destruir, de ter boas atitudes com a natureza para que ela seja preservada, entendida aqui no sentido de conservação dos recursos naturais.

Esse pensamento nos remete à concepção naturalizada da EA apresentada anteriormente, o homem por não fazer parte da natureza deve ter boas atitudes e bons comportamentos com ela para garantir sua conservação.

Devemos, portanto, considerar as diferenças conceituais entre atitude e comportamento nas práticas em EA. Conforme Carvalho (2004), atitudes tem um sentido mais amplo, "adoção de um sistema de crenças, valores e sensibilidades éticas e estéticas orientado segundo os ideais de vida de um sujeito ecológico" (p. 177). Assim, muito embora haja uma expressão de um comportamento socialmente aceito em relação à natureza não significa dizer que aquela pessoa tem uma atitude ecológica. A EA implica desenvolvimento de entendimentos e sensibilidades sobre os problemas ambientais com o objetivo de comprometer-se com as tomadas de decisões (CARVALHO, 2004).

A partir do pensamento de Carvalho (2004), consideramos que a professora, ao falar sobre ter uma boa atitude com a natureza, está se referindo a um comportamento ecologicamente correto, pois não há reflexão sobre as situações complexas que envolvem os problemas ambientais.

Sobre bons comportamentos há o relato das professoras com experiências em trabalhos com reciclagem. A professora Sara recordou que seu primeiro trabalho ligado a EA foi sobre reciclagem com alunos da Educação Infantil, considerou o trabalho importante, pois houve um envolvimento da turma na fabricação de "brinquedos de lixo com os meninos!" (entrevista, 07/04). A professora Laura compartilhou sua experiência também com projetos de reciclagem e procura desenvolver essa prática todos os anos com seus alunos "todo ano eu peço pros meus alunos fazerem brinquedos, confeccionarem brinquedos de material reciclado" (entrevista, 07/04).

No relato dessas professoras durante as entrevistas, não há, portanto, indícios de uma discussão sobre os problemas sociais causados pelo descarte dos resíduos sólidos nem sobre a situação de consumo presente no modelo de desenvolvimento econômico atual. Há um reconhecimento de uma prática em EA, porém nos preocupamos sobre como está prática se traduz dentro dos conceitos e objetivos de uma EA crítica.

Carvalho (2004) discute a ideia de que generalizar o termo EA "pode contribuir para uma apreensão ingênua da ideia contida nela" (p. 153). Assim, projetos e práticas 
pedagógicas que estimulem "boas práticas ambientais" ou "bons comportamentos" podem ser vistos como um possível trabalho em EA, porém acarretam um silenciamento das questões complexas relacionadas aos "conflitos sociais que se constituem em torno dos diferentes modos de acesso aos bens ambientais e de uso desses bens" (p. 153).

Assim, ao tratamos a prática pedagógica com ênfase comportamental podemos cair no risco de um ensino simplificado e à parte das questões que mobilizam a crise ambiental.

É possível que práticas de EA trabalhem com reflexões que incentivem a formação dos sujeitos para construírem atitudes, considerando o pensamento interdisciplinar e complexo ligados às questões ambientais e às relações entre seres humanos e natureza, construídas históricas, e socialmente, bem como ampliar as práticas para além de uma visão comportamental, discutindo valores e atitudes ecológicas, possibilitando uma possível mudança de pensamento na busca por uma mudança de racionalidade.

\section{b) Ênfase crítica}

Conforme apresentado por Carvalho (2004), uma EA crítica também está relacionada a compreender as relações entre o ser humano e a natureza, percebendo os problemas e conflitos ambientais e intervindo na busca de soluções, contribuindo, assim, para uma mudança de valores e atitudes.

Ao apresentar o trabalho do $1^{\circ}$ bimestre sobre a montagem de uma composteira, as professoras Letícia e Sandra, relatam:

Quando a gente levou esse assunto pra sala, por que é o projeto do $1^{\circ}$ bimestre, a gente vai trabalhar com o tema que é Alimentando o Brasil, pra gente chegar nesse assunto da composteira na verdade, tem que fazer todo um link, né! O que tem haver? Porque a composteira? Qual a causa? Assim, quais são as funções? Quais são os benefícios? E isso foi muito legal, que a gente foi pesquisando junto [...] Aí até eles conseguirem assimilar que a composteira é você reduzir seu próprio lixo para que não tenha um impacto maior no ambiente ou na vida do outro. É você pensar até que outros não têm a mesma oportunidade, o que comer. Isso é muito rico, tá sendo muito legal, né, porque a gente ainda está nesse processo de construção que vai culminar no dia da apresentação que vai ser a feira de ciências e que está sendo bem enriquecedor. (Letícia, $1^{\circ}$ encontro, 28/04/2016)

Que nem a gente estava conversando, aí eu estava procurando também sobre esse assunto e o desperdício de alimento é o $3^{\circ}$ emissor de $\mathrm{CO}$ no mundo, então assim, 
uma coisa que a gente acha simples, um restinho de comida que a gente joga, tem todo um impacto ambiental no mundo que a gente vive, né! Então assim, além de saber comer bem, ter uma alimentação sustentável e não desperdiçar os alimentos. [...] Isso que eu acho que é um EA né, do que a gente tá falando, não é disso? Porque você fala do dia a dia da pessoa, as ações que ela tem e que impacto ela tem na vida do outro. Que o ambiente que eu vivo, o que eu faço dentro dele vai impactar o ambiente das outras pessoas... é o efeito dominó que tem! (Sandra, $1^{\circ}$ encontro, 28/04/2016)

As falas apresentadas indicam um trabalho de EA que busca construir com os alunos os conhecimentos relacionados, nesse caso, à construção de uma composteira. O tema gerador do projeto desenvolvido no primeiro bimestre foi Alimentando o Brasil, a partir dele as professoras optaram por trabalhar sobre as questões do desperdício de alimentos. Podemos perceber que há uma construção coletiva do conhecimento, a professora Letícia menciona que a pesquisa foi feita junto com os alunos, assim como a professora Sandra traz os dados pesquisados sobre esse desperdício.

A prática das professoras indica a possibilidade da construção do conhecimento por meio do diálogo e reflexão com os alunos. As perguntas feitas pela professora Letícia demonstram uma contextualização quanto ao assunto que será trabalho no bimestre e sugere um envolvimento participativo das crianças nesse processo. Além disso, a professora Sandra ao destacar os problemas relacionados à emissão de $\mathrm{CO}$, nos indica que há um entendimento sobre o desperdício de comida gerando outros problemas ambientais, apontando uma percepção, mesmo que inicial, de questões mais complexas quanto a esse desperdício.

Outro fator que levamos em consideração a partir dos relatos das professoras é presença da preocupação com o outro. Há uma percepção quanto aos impactos individuais afetando o coletivo e uma problematização, ainda que discreta, de questões sociais, quando, por exemplo, a professora Letícia traz o pensamento sobre "até que outros não têm a mesma oportunidade, o que comer".

Ainda sobre esse pensamento, a professora Letícia nos apresenta:

De como também posso ajudar o meio ambiente! Porque os impactos negativos em cima de onde tem o lixão é o que a gente traz para eles, a conscientização das causas que isso pode trazer são grandes, né! E eles não tem dimensão, de repente, desses problemas ambientais, então é a questão das crianças que passam fome, a 
questão do solo que está sendo prejudicado, é toda uma situação. (Letícia, $2^{\circ}$ encontro, 05/05/2016)

Consideramos, portanto, que a prática pedagógica com a ênfase crítica aqui apresentada leva em consideração algumas questões quanto às relações humanas com a natureza e as relações com outros seres humanos.

Há traços de uma EA afinada com o pensamento complexo, percebendo as questões ambientais não apenas como locais, mas também globais. Ao assimilar e repensar as atitudes e as suas consequências para o global, aponta um possível caminho para o cuidado e responsabilidade com o meio ambiente e o próximo por meio de uma reflexão sobre os diferentes impactos que podem ocorrer no meio ambiente e na vida de outras pessoas.

A prática pedagógica apresentada pelas professoras nos oferece indícios de uma possível construção de projetos que trabalhem na perspectiva de uma EA crítica, rompendo com a lógica do conhecimento-regulação, que fragmenta e objetifica a natureza, para um trabalho interdisciplinar que considera o pensamento complexo e aponta para a construção de um novo saber que considera a responsabilidade com o próximo, bem como uma nova ética e novos valores sociais.

Apoiada na ideia de uma racionalidade ambiental, Leff (2013) nos mostra que entender a complexidade ambiental nos auxilia na promoção de uma mudança de pensamento e mentalidade, uma transformação dos conhecimentos possibilitando a construção de um mundo mais sustentável, justo e democrático.

Importante ressaltar que projetos desenvolvidos na perspectiva da EA crítica, requer de nós professores, uma possibilidade de mudança de visão sobre o meio ambiente e suas relações, sociais e culturais, conforme Carvalho (2004), compreender a natureza como ambiente, como um lugar de interação entre "a base física e cultura da vida nesse planeta" (p. $38)$.

Reconhecemos que ainda há muitas questões a serem consideradas na ênfase crítica aqui apresentada, porém as discussões e reflexões feitas pelas professoras revelam a possibilidade de trabalhar a EA crítica nos projetos escolares, apontando um caminho para um novo saber, a solidariedade. 


\subsubsection{EA e formação dos sujeitos}

Uma das principais aspirações da EA crítica é contribuir para a constituição de uma atitude ecológica, assim, a EA busca promover muito mais que informações e conteúdos, mas gerar "processos de formação do sujeito humano, instituindo novos modos de ser, de compreender, de posicionar-se ante os outros e a si mesmo, enfrentando os desafios e as crises do tempo em que vivemos" (CARVALHO, 2004, p. 69).

A formação dos sujeitos passa por uma tomada de consciência, conforme Paulo Freire (1967) pode ser entendida como a passagem dos níveis de consciência, de uma consciência intransitiva para uma consciência crítica, voltada para um reconhecimento das responsabilidades sociais e políticas, além de uma interação com os problemas sociais.

As palavras consciência e conscientização estiveram presentes nas discussões durantes as entrevistas e nos encontros da ação de formação, permitindo assim, uma análise sobre como ela pode estar associada à formação dos sujeitos. Entendemos, portanto, que o seu uso pode estar ligado a dois processos: informação e reflexão.

\section{a) Conscientização como repasse de informações}

Sobre o desperdício de papel, a professora Marta relata:

\footnotetext{
Não gosto que os meninos desperdiçam folha. Eu gosto que colem de uma maneira que economizem papel, sempre, sempre pensando na natureza. Não suje! Não jogue! Conscientizo eles que não pode espalhar lixo, não pode matar as plantas e os animais. (Marta, entrevista, 27/04/2016)
}

A professora comenta não gostar do desperdício de papel nas atividades escolares cotidiana dos alunos em sua sala, por isso ela ensina aos seus alunos a forma como devem ser feitas as colagens das atividades nos cadernos, de maneira que economizem o papel. Assim, a professora "conscientiza" seus alunos que não pode espalhar o lixo nem matar plantas e animais.

A professora Carla apresenta,

Ações que a gente pode realmente fazer, que dê resultados, esclarecer também sobre essas ações, sobre esses conceitos para que a gente possa trabalhar em sala, porque é algo que se pede hoje, uma conscientização ambiental. A gente tem lixo na rua, aquecimento global, falta de água, desperdício e eu acho que é bem aí, trazer essa conscientização também e saber falar disso com mais propriedade. (Carla, entrevista, 07/04/2016) 
O trecho acima está relacionado ao pensamento da professora sobre a formação continuada em EA, ela apresenta que é necessário esclarecer as ações e os conceitos como possiblidade de obtenção de uma consciência ambiental. A expressão "trazer essa consciência também" pode estar ligada ao esclarecimento dos problemas causados e citados por ela, como o lixo na rua, aquecimento global ou falta de água.

$\mathrm{Na}$ formação do sujeito, essa percepção pode estar ligada à consciência transitiva ingênua, mencionada por Paulo Freire (1967), em que há uma simplificação na interpretação dos problemas. A professora Marta informa aos alunos como devem se comportar, ou seja, palavras imperativas "não suje" ou "não jogue" sugerem uma formação que não prioriza o diálogo e aponta para uma fragilidade na argumentação.

Ao conscientizar os alunos sobre os problemas ambientais existentes, a professora Carla corresponde com o que, segundo ela, se pede hoje: uma consciência ambiental. Assim, as informações contribuiriam para as ações corretas que os alunos deveriam ter sobre as questões ambientais.

As palavras apresentadas nesse contexto nos remetem ao pensamento de EA ligado à concepção cognoscitiva citada anteriormente, assim ao informar algo para o meu aluno, ele toma consciência do que pode ou não pode fazer. Nesse contexto, não há espaço para uma formação crítica, o que importa é a transmissão das informações, aqui entendidas como conhecimento, sendo a formação marcada pelo acúmulo de informações para uma réplica, reafirmando a postura do "bom comportamento" como possível garantia de sucesso das práticas de EA.

Quanto à formação dos sujeitos a partir do compartilhamento de informações, seria importante diferenciarmos informação de conhecimento. Segundo Almeida (2010), "podemos dispor de informações e não construir conhecimento algum" (p.70), pois o processo de conhecer requer "selecionar informações, articulá-las entre si e imputar significado a elas. Conhecimento é tratamento de informações" (p.71).

Além disso, caberia dialogar com duas inquietações apresentadas por Gastal e Avanzi (2016): a aposta exclusiva na razão como processo de decisão e um descompasso entre a intenção libertadora e uma tendência à padronização, em que a ciência produziria o conhecimento e a escola apontaria a razão como caminho único. Nessa percepção o sujeito é reduzido à dimensão da razão.

Entendemos, portanto, a importância da formação dos sujeitos superar uma visão do repasse das informações, reconhecendo o par razão e emoção no processo de produção de 
conhecimentos com espaços para "ampliação de leituras de mundo que resultem de encontros entre diferentes contextos culturais" (GASTAL; AVANZI, 2016, p. 229).

Quanto à consciência transitiva ingênua apresentada por Paulo Freire (1967), a sua não promoção ao estado de consciência crítica pode acarretar na massificação dos sujeitos e seu descompromisso com a realidade em que estão inseridos.

Portanto, para a formação crítica dos sujeitos em EA faz-se necessário superar a construção de uma consciência ingênua, na medida em que levamos em consideração o homem como ser capaz de tomar suas decisões a partir do reconhecimento das suas realidades e do diálogo.

\section{b) Conscientização como processo reflexivo}

Segundo Carvalho (2004) a formação dos sujeitos na EA crítica só fará sentido "se pensada em relação com o mundo em que ele vive e pelo qual é responsável” (p. 156). Para Paulo Freire (1967) essa formação representa a transitividade para uma consciência crítica que não ocorre de forma espontânea, mas com uma educação que tenha esse objetivo, ou seja, que considere a reflexão como um dos processos que auxiliam na formação.

Como já vimos em nossas análises, percebemos indícios de uma prática pedagógica que possibilita a formação crítica dos sujeitos a partir de uma concepção histórica-social sobre a EA e a ênfase crítica nos projetos desenvolvidos pelas professoras. Mesmo que ainda discretas, podemos considerar o uso da palavra conscientização no sentido de reflexão sobre questões ambientais.

Relembraremos algumas falas das professoras Sandra e Letícia:

conscientizar esses alunos que o mundo não é só aqui onde a gente vive, a nossa casa e a nossa escola, é muito maior que isso, que as ações que a gente tem, tem impacto social e ambiental na nossa vida e na do outro... o que eu fizer vai impactar na vida do outro também. (Sandra, entrevista, 07/04/2016)

Porque os impactos negativos em cima de onde tem o lixão é o que a gente traz para eles, a conscientização das causas que isso pode trazer são grandes, né! E eles não têm dimensão, de repente, desses problemas ambientais, então é a questão das crianças que passam fome, a questão do solo que está sendo prejudicado, é toda uma situação. (Letícia, $2^{\circ}$ encontro, 05/05/2016) 
Hoje eu tenho essa preocupação, de passar pros alunos do lixo que é produzido, pra onde vai, porque eles não têm isso, né!? Hoje a gente tem uma conscientização maior, pra eles entenderem pra onde vai, de onde vem, o que é feito com tudo isso! (Letícia, $3^{\circ}$ encontro, 12/05/2016)

Ao utilizar a palavra conscientizar, podemos inferir que a professora Sandra não busca apenas informar aos alunos sobre as questões ambientais, mas há uma preocupação em estimular uma reflexão sobre efeitos das ações individuais e coletivas no meio ambiente. Para a professora Letícia, o termo "uma conscientização maior" sugere uma abordagem de se estudar além dos conteúdos pretendidos, mas uma possível reflexão envolvendo outras questões socioambientais relacionadas ao lixo.

Para Freire (1980) a educação “deve estabelecer uma relação dialética com o contexto da sociedade à qual se destina" (p. 35), ou seja, a formação dos sujeitos deve considerar a relação do ser humano com o mundo em que vive, passando assim, a ser um sujeito crítico.

Vejamos outro depoimento da professora Sandra:

Essa questão de conscientizar o aluno com relação a esses impactos tem uma coisa que é tão simples que às vezes as pessoas não percebem, dessa ação que a gente tá falando, ação individual afeta o coletivo, o coletivo também afeta o individual, enfim, eles não têm consciência. (Sandra, $2^{\circ}$ encontro, 05/05/2016)

Podemos inferir que a professora demonstra uma preocupação para que os alunos percebam que suas atitudes individuais afetam o coletivo e que são afetados também com as ações coletivas. A palavra conscientização nos remete à possibilidade de uma reflexão sobre essas relações.

Consideramos, portanto, que a formação crítica dos sujeitos apresenta uma visão socioambiental, conforme Carvalho (2004), “é necessária uma visão complexa de meio ambiente, em que a natureza integra uma rede de relações não apenas naturais, mas também sociais e culturais" (p. 38).

O processo de formação crítica dos sujeitos está em sua capacidade de se perceber e conhecer a realidade em que está inserido e as relações nela existentes, ampliando seu poder de compreensão a partir de uma reflexão sobre si mesmo, sobre suas responsabilidades e seu papel, possibilitando tomadas de decisão e intervenção na realidade.

A conscientização, para Freire (1979), implica ultrapassar “a esfera espontânea de apreensão da realidade, para chegarmos a uma esfera crítica na qual a realidade se dá como 
objeto cognoscível e na qual o homem assume uma posição epistemológica" (p. 15), ou seja, ela não pode existir sem o reconhecimento da realidade e ação sobre ela, através da reflexão.

A transitividade da consciência crítica, portanto, está pautada em uma educação que possibilita o diálogo, a reflexão e a construção do conhecimento, superando a visão verticalizada e unidirecional do processo formativo. Segundo Gastal e Avanzi (2016) "pensar a escola como um lócus de problematização de tais supostas verdades únicas, um espaço de desconstrução de posturas prescritivas e de busca pela ampliação de leituras de mundo que resultem de encontros entre diferentes contextos sociais" (p. 28).

Ao considerar a conscientização como processo reflexivo na formação dos sujeitos, buscamos compreender uma EA que possibilite o reconhecimento do sujeito, não apenas no mundo, mas com o mundo, reconhecendo as relações existentes entre os seres humanos e com a natureza, reconhecendo seus processos históricos e culturais, capaz de intervir na realidade e transformá-la, se abrindo para o diálogo, a reflexão e possiblidade de novos saberes.

\subsection{Formação continuada de professores}

Com o objetivo de responder algumas questões desta pesquisa, durante a entrevista questionamos as professoras sobre o papel da formação continuada na prática docente e o que seria a formação de professores em EA. Nas respostas é possível identificar reflexões a respeito da importância e finalidade da formação continuada, bem como de sua relação com a prática docente.

A primeira ideia defendida pelas professoras foi sobre a importância dessa formação.

Formação continuada? Sim! Super importante. Eu acho que o professor tem mesmo que ir atrás de conhecimento até para poder aplicar no seu dia a dia em sala de aula mesmo. É construindo um conhecimento mesmo, sempre, né, por isso eu acho que sim, é importante a formação continuada. (Letícia, entrevista, 07/04/2016)

Assim, é de extrema importância, né! Nós, professores, estamos sempre procurando novas informações, porque assim... é... a cada vez vai passando mais o tempo e as coisas vão se modificando, né! Então, eu acho de extrema importância nós estarmos sempre nos capacitando, nos atualizando. Muitos não dão valor nessas formações que a gente tem, por exemplo, eu mesma, todo semestre, eu faço curso na EAPE! (Laura, entrevista, 07/04/2016) 
Nesses depoimentos é possível identificar dois sentidos atribuídos à formação continuada: "aplicabilidade" e "busca por novas informações". Além disso, essa formação não é entendida apenas como curso, mas tudo aquilo que a professora procura, na forma de um texto, um vídeo ou uma palestra:

Tudo o que eu busco além, a leitura de um livro que eu pego, um assunto. Por exemplo, agora eu estou com $5^{\circ}$ ano tem algum tempo, então eu estou mais na temática pré-adolescente porque meu mundo antes era os menores, então eu tinha aquela coisa, era música, era vídeo, era tudo isso ligado para o infantil. Agora não, estou na fase mais adolescentezinho. Então eu pesquiso os livros, o que está se passando, o que tem no mundo da televisão para eles, o que eles acham. Desenhos! Assisto os desenhos todos porque você acaba tendo assunto também pra lidar e acaba tirando algumas coisas pra vivenciar com eles também. Então eu acho que formação continuada é o contexto, é tudo! (Sara, entrevista, 07/04/2016)

A preocupação da professora Sara nos mostra que, ao buscar novas formas de trabalho e novos assuntos para interagir com os alunos, reconhece a necessidade de uma formação continuada. O docente pode estar em constante movimento de formação, mesmo que não seja em cursos presenciais ou a distância. O processo de formação é marcado pelo movimento que o professor faz ao se deparar com novas situações e a busca constante para sua profissionalização.

Outra interpretação possível a partir dos depoimentos das professoras é a de que a procura pelos cursos, na sua maioria, está relacionada a uma necessidade atual, e que, prioritariamente, deve auxiliar a prática docente. No trecho da professora Sara transcrito acima, notamos que o fato de antes trabalhar com alunos de $3^{\circ}$ ano passando a trabalhar com alunos de $5^{\circ}$ ano a leva a buscar constantemente textos e assuntos relacionados a essa faixa etária. Temos também como exemplo um relato da professora Marta, que ao ter oportunidade de trabalhar com uma turma de Transtorno Global de Desenvolvimento ${ }^{5}$, buscou fazer um curso e assistir palestras sobre o tema. A professora Sandra, por sua vez, ao perceber que poderia trabalhar com alunos com dificuldades na alfabetização, priorizou esse tema ao escolher o curso que faria.

\footnotetext{
${ }^{5}$ Conforme MEC/ SECADI, Política Nacional de Educação Especial na Perspectiva da Educação Inclusiva (2008), os estudantes com transtornos globais do desenvolvimento são aqueles que apresentam alterações qualitativas das interações sociais recíprocas e na comunicação, um repertório de interesses e atividades restrito, estereotipado e repetitivo.
} 
As professoras valorizam uma formação continuada que traga contribuições a sua prática docente e demonstram um maior interesse em participar de um curso quando a escolha é livre, não por obrigação, mas por seu desejo e vontade:

Quando você escolhe o curso que você quer fazer, você tem um gostinho a mais do que algo que vem proposto apesar de estar tudo 'linkado' ali, no seu... é... o que eu quero dizer é que está tudo 'linkado' aqui na escola, algo que vai ser aplicado em sala, que vai ser um tema que às vezes não vai ser aplicado em sala mas que vai fazer diferença no meu trabalho né, então é válido! (Letícia, entrevista, 07/04/2016)

Os depoimentos nos permitem inferir o que essa formação representa para as professoras. Agrupamos seus depoimentos em três categorias: a) capacitação ou instrumentalização; b) atualização ou aquisição de informação; c) relação teoria-prática.

\section{a) Formação como capacitação ou instrumentalização}

A capacitação do profissional pode estar ligada ao significado da palavra capacitar que, conforme o Dicionário Web significa "preparar a pessoa para enfrentar as situações inerentes à sua função, através da aplicação e conhecimentos, mas com possibilidade de criar, resolver adversidades, sugerir alternativas de progresso e criar ambiente adequado". Nesta noção, o profissional não é apenas um mero transmissor ou aplicador das informações obtidas.

Podemos observar nas palavras da professora Sandra referentes à formação continuada uma possibilidade de capacitação para o auxílio na busca de novas metodologias de ensino.

É aquela que o profissional está sempre em busca de novas formas de... no meu caso por exemplo, professora, várias formas de desenvolver a aprendizagem dos alunos né, dinâmicas pra trabalhar em sala de aula, é conhecer também até nós mesmos como profissionais, né, cursos que possam melhorar nosso desenvolvimento em sala de aula com os meninos, pra tentar atingir os nossos objetivos, né. Então, sempre, no meu caso, valorizando o meu trabalho como educadora e pra que isso também possa atingir meus alunos. (Sandra, entrevista, 07/04/2016) 
Para a professora Sara, a noção de formação continuada está também relacionada ao auxílio na aquisição de novos conhecimentos que a capacitam para melhor trabalhar com seus alunos.

\footnotetext{
Ainda mais que quando é um assunto que eu sei que eu vou, vou conseguir ter uma formação maior pra trabalhar com os meus alunos, entendeu? Então, me dá uma segurança maior de trabalhar aquilo com eles e eu me sinto bem melhor. (Sara, entrevista, 07/04/2016)
}

Imbernón (2011) apresenta a formação de professores baseada nos programas de formação no desenvolvimento de competências que possibilitem determinados tipos de estratégias, visando à mudança, ou seja, os professores são vistos como agentes de mudanças, tanto individual como coletivas. $\mathrm{O}$ autor entende que a formação também possa contribuir para que tenham clareza sobre o que devem fazer e, sobretudo, o porquê fazê-lo.

Em suas palavras,

\footnotetext{
Um fator importante na capacitação profissional é a atitude do professor ao planejar sua tarefa docente não apenas como técnico infalível, mas como facilitador de aprendizagem, um prático reflexivo, capaz de provocar a cooperação e participação dos alunos (IMBERNÓN, 2011, p. 40-41).
}

É importante que a formação de professores leve em consideração o protagonismo do docente no seu desenvolvimento profissional, no planejamento e reformulação de estratégias da sua ação docente. Assim, é importante considerar a formação de professores pautada na reflexão, possibilitando que os docentes intervenham sobre sua prática, aprendendo a interpretar e desenvolver estratégias ligadas à realidade em que estão inseridos.

Essa formação proposta faz contraponto a uma formação tecnicista, ou seja, aquela que intenta formar o professor como um especialista técnico, transmissor do conhecimento. A formação apresentada por Imbernón (2011) visa "dotar o professor de instrumentos intelectuais que sejam úteis ao conhecimento e à interpretação das situações complexas em que se situa" (p. 42).

Ao analisar a fala da professora Carla, nos indagamos sobre o uso da palavra instrumentalizar. Seria no sentido mencionado por Imbernón quanto ao protagonismo na produção de novos conhecimentos ou estaria no sentido apenas operacional? 
Bem, eu acredito que a formação ela só contribui pra nossa prática, né! Ela nos instrumentaliza, ela nos traz possibilidades de trabalhar com os meninos, os meninos com dificuldades, os meninos que aparentemente não as tem, pra gente, né! (Carla, entrevista, 07/04/2016)

O uso dessa palavra pela professora Carla nos remete à ideia da aplicabilidade de estratégias, assim, estaria ligada à aquisição de instrumentos para a realização de algo. Para Imbernón (2011) a ideia de dotar os professores com instrumentos intelectuais vai além do acesso a um conjunto de técnicas, está ligada à produção de conhecimentos, habilidades e atitudes no desenvolvimento de um profissional reflexivo.

Para a formação continuada de professores em Educação Ambiental é importante superar a ideia de formação como instrumentalização, ou seja, ela não está pautada no repasse de informações que auxiliem mecanicamente a realização da prática. A proposta é a formação de profissionais capazes de refletir sobre a prática, não somente dentro da escola, mas em conjunto com a realidade social onde estão inseridos.

A formação em EA pode auxiliar os profissionais a ampliar a visão de uma formação apenas como instrumento para desenvolver sua prática, buscando a superação do fazer técnico para um fazer comprometido com uma busca por um novo saber, podendo este ser criado e recriado pelo próprio professor a partir da reflexão na sua prática docente, no diálogo com seus pares e com os discentes, na medida em que ambos estão em processo de formação.

Entendemos, portanto, que a capacitação do professor em EA se dá por meio de uma reflexão sobre sua prática buscando assim, novas abordagens metodológicas, abrindo caminhos para um novo pensar, superando a visão tradicional de transmissão de conteúdos para uma visão em que há possiblidades de diálogos com as diferentes formas de pensar e agir, assumindo o contexto social e cultural, bem como as relações existentes dos humanos com a natureza e com o próximo, não reduzindo essas relações a uma racionalidade técnica, mas na busca por uma reconfiguração dessas relações buscando novos valores, atitudes, uma nova ética ecológica. 


\section{b) Formação como atualização ou aquisição de informação}

Outro sentido que "formação" assume nos depoimentos dos sujeitos desta pesquisa está relacionado à ideia de atualização de informações. As professoras demonstram uma preocupação quanto à rapidez da circulação de informações em nossa sociedade e mencionam a necessidade de uma formação que as auxilie a lidar com isso no processo de ensinoaprendizagem.

\footnotetext{
O que eu considero importante? Assim, no meu ponto de vista, é... hoje em dia a gente tem acesso a informação muito rápido, os alunos então! Sempre quando tem uma catástrofe natural ou alguma coisa assim... da gente estar antenada com aquele assunto, como trabalhar em sala de aula aquilo ali, como "linkar" isso aos conteúdos para não ficar uma coisa vaga, uma coisa solta, então o curso de formação voltado para esse assunto pode ajudar a gente nesse aspecto. (Sandra, entrevista, 07/04/2016)
}

A formação dos sujeitos ocorre de diversas formas e em diversos locais e tempos, porém, quando falamos em educação escolar, devemos pensá-la de modo complexo. Conforme Pimenta (2008), a educação apresenta, reproduz e projeta a sociedade que se quer, estando vinculada aos processos civilizatórios e humanos.

Assim, é fato que em uma sociedade dinâmica como a sociedade contemporânea, uma grande quantidade de informação é transmitida rapidamente de um lugar para o outro, mas não podemos tratar informação como sinônimo de conhecimento. $\mathrm{Na}$ mesma perspectiva de Almeida (2010), apresentada anteriormente, para Pimenta (2008) conhecer é mais do que obter informações, significa trabalhar a informação na perspectiva de transformá-la em conhecimento, sendo uma responsabilidade dos professores, "um profissional preparado científica, técnica, tecnológica, pedagógica, cultural e humanamente. Um profissional que reflete sobre o seu fazer, pesquisando-o nos contextos nos quais ocorre” (p. 39).

Para Imbernón (2011) é parte da formação do professor também dedicar uma atenção especial sobre como os professores elaboram a informação nas situações da docência e como essa elaboração se faz presente nos planos da ação docente e na sua prática. Essa formação se fundamentará em estabelecer "estratégias de pensamento, de percepção, de estímulos; estará centrada na tomada de decisões para processar, sistematizar e comunicar a informação" (p. 41). Assim, mais uma vez temos a importância da reflexão sobre a prática.

Retomamos a observação apresentada pela professora Laura: 
Nós, professores, estamos sempre procurando novas informações, porque assim... é... cada vez vai passando mais o tempo e as coisas vão se modificando, né! Então, eu acho de extrema importância nós estarmos sempre nos capacitando, nos atualizando. Muitos não dão valor nessas formações que a gente tem, por exemplo, eu mesma, todo semestre, eu faço curso na EAPE né! (Laura, entrevista, 07/04/2016)

Na perspectiva apresentada por Pimenta (2008), a formação do professor está além do acúmulo de informações. Podemos inferir que ao citar as palavras capacitação e atualização ligadas ao processo de formação, a professora Laura faz menção à obtenção de uma preparação para enfrentar situações diárias em sala de aula, aplicando o conhecimento adquirido, não apenas replicando as informações.

Quanto à formação continuada ser um processo de atualização e capacitação devemos ter o cuidado apresentado por Miguel Arroyo (1999), não formar apenas profissionais que executam tarefas, ou conforme Pimenta (2008) ser apenas um modo de requalificação, fazendo da educação continuada apenas um grande mercado.

A busca por uma atualização, conforme mencionada pelas professoras, pode se dar no processo de reflexão sobre as informações obtidas e na transformação dessas em conhecimento. No que diz respeito à EA, Penteado (1994) nos faz refletir que, para além das informações sobre as questões ambientais, como os direitos e deveres previstos em lei, sobre o que é o meio ambiente ou como os elementos do meio ambiente se transformam e reagem aos seres humanos, é importante levar em consideração a vivência e a maneira como as informações são adquiridas e o que vai ser provocado no desenvolvimento da formação. Como ela nos mostra:

Uma coisa é ler e aprender os direitos e deveres definidos em uma Constituição, outra coisa é descobrir com as pessoas como estão lidando com estes direitos e deveres, na sua vida cotidiana e com que resultados. [...] Um coisa é ler sobre o meu meio ambiente e ficar informado sobre ele, outra é observar diretamente o meu meio ambiente, entrar em contato direto com os diferentes grupos sociais que o compõem, observar como as relações sociais permeiam o meio ambiente e o exploram, coletar junto às pessoas informações sobre as relações que mantêm com o meio ambiente em que vivem, enfim, apreender como a sociedade lida com ele. Agir assim é experimentar comportamentos sociais em relação ao meu meio ambiente que permitem constatar suas características e as reações dele à nossa atuação. (PENTEADO, 1994, p. 53). 
Nessa perspectiva, Carvalho (2004) nos chama a atenção sobre as possíveis "armadilhas de uma cientificidade normativa e tecnicista" (p. 124) que influenciam nossa prática pedagógica tornando os conhecimentos científicos ligados às questões ambientais na sua forma ingênua, ou seja, não havendo a "problematização dos contextos históricos de produção e dos interesses econômicos aos quais respondem" (p. 124). O que esta autora nos apresenta é que podemos utilizar os conhecimentos científicos como base para uma compreensão das relações socioambientais. Dessa forma, as informações não seriam apenas acumuladas pelos alunos, mas transformadas em conhecimento para a formação critica dos sujeitos.

Nesse sentido, a formação continuada para uma EA crítica busca superar o conhecimento científico como verdade absoluta e possibilita a busca por novos saberes, que resultem do diálogo entre diferentes áreas e diversas formas de conhecimento.

\section{c) Formação como relação entre teoria e prática docente}

Nóvoa (1992) apresenta a formação de professores como algo que pode auxiliar na “configuração de uma 'nova' profissionalidade docente" (p. 12) à medida que ela se configure numa perspectiva crítico-reflexiva, que permita ao professor um pensamento mais autônomo, facilitando sua auto-formação. Essa formação de que nos fala o autor, no entanto, não está baseada no acúmulo de cursos ou conhecimentos e técnicas, mas num processo de reflexão sobre sua prática e de construção e reconstrução de sua identidade, assumindo a responsabilidade sobre seu desenvolvimento profissional e que seja participante da implementação de políticas públicas.

Esta categoria traz depoimentos das professoras que sugerem a busca por uma postura reflexiva. Um dos aspectos da postura reflexiva se refere ao estabelecimento de relações entre teoria e prática pedagógica, mas esta relação estaria implícita na "aplicabilidade” mencionada por Letícia?

Eu acho. Quando um curso tem o formato de uma aplicabilidade na sala eu acho que é mais viável e eu acho que o interesse é maior, eu tiro por mim, né! Eu dou algo que eu possa conseguir levar pra sala, pros meus alunos, de novidade, de conhecimento, até de desafio... (Letícia, entrevista, 07/04/2016)

Parece que não! 
A professora Sara também mostra uma preocupação quanto à aplicação da teoria na prática:

Achei muito interessante porque muita coisa eu não sabia que dava pra você trabalhar com o aluno, pra você aproveitar, pra você ver de uma forma diferente. Trabalhamos as questões dos biomas, que eu achei bem legal, tanto é quando eu vou trabalhar com os meninos, eu trago só mapas pra mostrar e eles são coloridos. Porque eu acho legal, interessante, até hoje eu gosto de trabalhar. Fizemos jogos no curso, né! Com os tipos de mapas e tudo! Levei pra sala depois, trabalhei com os meninos, mas com o tempo se perdeu, mas foi bem legal! Eu tinha um do cerrado que eu adorava! Que era uma trilha do cerrado, tinha umas perguntinhas. O curso foi bem bacana, tinha a parte teórica, mas tinha a parte prática, tinha a aplicação! (Sara, entrevista, 07/04/2016)

A formação continuada permite isso. E o curso de formação quando é colocado pra ser feito que a gente não procura, pode até desagradar, né: 'eu não queria fazer isso'. Mas de certa forma acaba aprendendo alguma coisa pra levar pras crianças também, que eu acho que se não tiver aplicação não tem fundamento de ser feito! (Sara, entrevista, 07/04/2016)

Assim, a parte que dificulta é essa, o excesso de coisas. E o que facilita é a questão da aplicação. Por que se você está na sala não custa você pegar o que eu você tá aprendendo e aplicar e fazer um relatório, é legal até, né! Saber se está sendo válido, você dá um retorno: "ah isso funcionou... isso não funcionou... isso é legal... ah! podia ser assim porque na minha sala funcionou assim..." Então, o legal é isso, eu acho bacana de ser na escola e você poder aplicar na escola é você vivenciar. (Sara, entrevista, 07/04/2016)

O que podemos perceber para as duas professoras é que a palavra aplicar está ligada ao replicar de técnicas passadas em um curso sobre um determinado assunto, e conforme Roldão (2007) essa leitura aplicacionista é evidenciada como dominante entre os docentes. A autora considera que a "fórmula relação teoria-prática transporta uma conceptualização simbólica que pode ser pouco operativa, ocultando a íntima dependência de um campo diante do outro" (p. 98), ou seja, os dois campos são apenas traduzidos em processos de aplicação, sendo da teoria à prática.

A busca por aplicabilidade parece ser compreendida pelas professoras como um desdobramento da atualização de informações mencionada anteriormente, uma busca de um 
modelo a ser reproduzido em sala de aula. Como vimos, para se tornar conhecimento, a atualização requer um processo de reflexão sobre as informações obtidas. Libâneo (2008) nos apresenta dois tipos de reflexividade, sendo uma de cunho neoliberal e outra de cunho crítico. A reflexividade neoliberal está situada no campo do tecnicismo, da racionalidade instrumental, já a reflexividade crítica apresenta a ideia reconstrucionista social, comunicativa e comunitária. Ao falar sobre reflexividade, o autor considera como uma capacidade intrínseca ao ser humano, uma "capacidade de pensarmos sobre nossos atos, sobre as construções sociais, sobre as intenções, representações e estratégias de intervenção" (p. 62).

Sobre o professor reflexivo, Libâneo (2008) reconhece que o trabalho do professor é um trabalho prático, porém, deve-se ter cuidado, pois a reflexão sobre a prática por si não resolve tudo, são "necessárias estratégias, procedimentos, modos de fazer, além de uma sólida cultura geral, que ajudam a melhor realizar o trabalho e melhorar a capacidade reflexiva sobre o que e como mudar" (p. 76).

Tardif (2012) apresenta a prática docente não apenas como um lugar de aplicação de saberes vindos da teoria, mas um espaço de produção de conhecimentos, ou seja, um espaço de transformação, produção e mobilização dos saberes. O docente passa a ser "um sujeito do conhecimento, um ator que desenvolve e possui sempre teorias, conhecimentos e saberes de sua própria ação" (p. 235).

Silva (2011), ao mencionar a relação teoria e prática na formação de professores nos apresenta os cuidados que devemos ter para não replicar a ideia da racionalidade técnica, ou uma epistemologia positivista da prática. Segundo a autora, "a atividade profissional é concebida como instrumental e é dirigida para a aplicação rigorosa de técnicas específicas a serem repetidas" (p. 20-21). Outro cuidado apresentado é o de não sobrepor a prática à teoria, o que a autora denomina de 'epistemologia da prática', ou seja, em alguns casos a formação teórica não aparece ou é tratada com menor relevância. A reflexão sobre a prática não pode estar ligada apenas à aquisição dos conteúdos para resolução de problemas imediatos, mas ela pode considerar a educação como um processo de formação social e política dos sujeitos.

Para Imbernón (2011) a formação permanente do professor consiste em descobrir, organizar, fundamentar, ensinar e construir a teoria, ela deve ser pautada na reflexão sobre sua prática, permitindo assim, uma avaliação das suas teorias, atitudes e funcionamento, ou seja, permite um processo constante de auto-avaliação. A postura reflexiva exige uma criticidade em relação às intervenções educativas, análise dos pressupostos teóricos e 
comportamentais. "Uma formação deve propor um processo que dote o professor de conhecimentos, habilidades e atitudes para criar profissionais reflexivos ou investigadores" (p. 55).

Assim, entendemos a necessidade de formação continuada baseada numa perspectiva da práxis, em que teoria e prática se manifestam na ação docente, na formação cidadã de sujeitos situados em uma sociedade, capazes de tomar decisões conscientes e críticas. Entendemos, então, a importância da formação continuada dos professores estar pautada numa prática reflexiva, na qual há possibilidades de auto-avaliação crítica para a sua formação, embasando sua prática e fortalecendo o caráter profissional da docência.

Este outro depoimento destaca a busca por conhecimentos teóricos relacionados à prática;

\footnotetext{
A gente nunca sabe, o que a gente sabe é muito pouco, entendeu! Então eu acho que uma formação, eu poderia aprimorar os meus conhecimentos teóricos, sempre ligados com a prática, entendeu! Então eu acho que esse curso, essa formação, que a gente vai ter, vai ser de grande valia porque vai me ajudar, porque às vezes a gente tem vontade, mas não sabe por onde começar, assim, vai ser um norte pra mim, entendeu! (Laura, entrevista, 07/04/2016)
}

A preocupação da professora Laura quanto a aprimorar os conhecimentos teóricos está de acordo com o pensamento apresentado por Pimenta (2008) sobre a importância da teoria na formação dos professores, pois conforme a autora, "o saber docente não é formado apenas da prática, sendo nutrido pelas teorias da educação" (p. 24), desse modo consideramos a importância da presença da EA em documentos normativos da educação, tais como as Diretrizes Curriculares Nacionais da Educação Básica (DCNEB) e as Diretrizes Curriculares Nacionais para a Educação Ambiental (DCNEA), ser acompanhada de políticas públicas de formação docente.

No entanto, caberia investigar como esses conhecimentos teóricos se relacionam com os saberes que as professoras trazem consigo. Ainda a partir de Nóvoa, destacamos a importância de um diálogo a partir da valorização dos saberes de que os professores são portadores e não a imposição de novos saberes ditos "científicos" o que reforçaria a lógica da racionalidade técnica, opondo-se ao desenvolvimento de uma práxis reflexiva. 


\section{CAPÍtulO 5}

\section{Narrativas e formação continuada: conectando tecidos e aplicações}

Escolhemos o uso das narrativas autobiográficas como parte do processo de formação continuada para as professoras participantes da ação de formação. Como já dissemos, foram seis professoras participantes, porém no decorrer da ação, percebemos que mais uma professora estava em formação, eu, professora Tâmia Teles. Assim, construí minha narrativa e compartilho, juntamente com as reflexões das docentes participantes.

Vamos compartilhar parte das reflexões das professoras registradas no diário de bordo e algumas considerações feitas durante as discussões nos encontros realizados. Não temos a pretensão de analisar essas reflexões feitas pelas professoras, mas apenas compartilhá-las dando ênfase ao caráter formativo das narrativas.

Cresci ao lado da máquina de costura da minha mãe. No meu imaginário infantil, aquela máquina já foi de tudo: carro, ônibus, avião, até nave espacial. Foi com minha mãe que aprendi que, se usasse minhas mãos, poderia fazer lindas peças.

Meus pais foram meus primeiros professores, entre tantas lições a que mais marcou foi que eu tinha a liberdade de servir a um Deus, não uma religião, mas um Deus amoroso.

Seguindo os passos de minha mãe, me tornei professora, o encantamento por essa profissão demorou um pouco, mas depois de dois anos e muitas experiências me apaixonei por essa profissão e hoje posso dizer com orgulho, sou professora.

Em minha caminhada estudantil cheguei ao mestrado, além de buscar maior conhecimento para minha profissão, nele estava a realização de um sonho - sim, sonhos são possíveis de realizar! Na proposta do mestrado vi a possibilidade de juntar duas paixões, ser professora e educadora ambiental.

Como já mencionei, o mestrado era um sonho, e aí, quando ele se tornou realidade fiquei perdida, o que fazer com algo que antes estava na minha cabeça e agora está nas minhas mãos?

Foi aí que minha orientadora - aliás, esse nome lhe cabe muito bem, me estendeu suas mãos e começamos a construir juntas esta pesquisa. Foi ainda no primeiro semestre que ouvi dela a comparação da feitura do projeto com uma peça de artesanato. Me encantei, voltei a minha infância, à velha máquina de costura da minha mãe. 
Dentre tantas opções e caminhos para formação continuada de professoras e EA, nossas escolhas foram baseadas na possibilidade de encantar as pessoas que iriam receber, e também tecer junto, este projeto. Por ser professora e entender a dinâmica de uma escola, uma das minhas preocupações era apresentar a nossa ação de formação de uma forma leve, ou seja, uma forma para que as professoras entendessem que essa ação não estaria à parte do trabalho, ou que seria mais um trabalho a ser feito na escola, mas que seria parte integrante dos projetos e da sua prática cotidiana.

As narrativas autobiográficas surgem no decorrer do mestrado. Fui apresentada a elas pela professora Maria Luíza Gastal, querida Malu, com a disciplina "Escuta, leitura e escrita no Ensino de Ciências" e em nosso grupo de estudo ${ }^{6}$. Me encantei! A partir da leitura de alguns autores como Ferraroti (2010), Josso (2010), Larrosa (2001, 2011), Bueno (2002, 2006) vi a possibilidade do professor fazer parte diretamente do seu processo formativo, dar escuta à voz do professor, resgatar seu lugar nesse processo de formação, ser autor da sua história!

Assim, eu e minha orientadora buscamos construir a proposta de formação. Gosto da palavra construir, as coisas não estão prontas. Existe um tempo para a confecção, elaboração, planejamento... e muitos foram os momentos de construção. Dentro desse período existem os sentimentos, todos legítimos, as incertezas, os medos, as alegrias, a satisfação!

Chegamos à escola, um ambiente familiar pra mim, rostos conhecidos, sorrisos acolhedores e braços estendidos. Encontrei ali mais uma parceria, mais mãos estendidas e prontas para juntas, confeccionarmos nosso projeto.

Os diários de bordo foram apresentados no primeiro encontro. A primeira impressão não foi a mais acolhedora, os olhares entre elas me revelaram uma certa desconfiança e receio, compreendi, me identifiquei com esse sentimento, eu também estava receosa. Nas minhas experiências com formação continuada, não me recordo de participar de um curso que estimulasse a prática reflexiva. O registro das minhas reflexões também era novidade pra $\operatorname{mim}$.

Ao explicar como seria o trabalho nos diários, a professora Letícia fez um comentário que chamou a minha atenção "vai ser meu confidente, o diário". Gostei da palavra,

\footnotetext{
${ }^{6} \mathrm{O}$ grupo de estudos é composto por discentes de mestrado e doutorado dos Programas de Pós-graduação em Ensino de Ciências (PPGEC) e Educação em Ciências (PPGEduc), da UnB, e pelas orientadoras Maria Luiza Gastal e Maria Rita Avanzi e tem o intuito de estudar as bases teóricas e metodológicas sobre narrativas autobiográficas na pesquisa e na formação de sujeitos.
} 
confidente, nos remete à ideia de intimidade, assim, acredito que a ideia de compartilhar um diário de bordo se tornou mais leve pra nós, pois abriu a possibilidade de não ser visto como uma obrigação, pra mim se revelou como possibilidade de conhecer, de descobrir coisas novas.

Nossos encontros foram marcados pela expectativa. Me identifiquei com um texto de Larrosa (2010) que narra as preocupações de um professor ao entregar um texto aos seus alunos, assim como se entrega um presente ou uma carta, há sempre uma preocupação "para saber se seu presente foi aceito, se sua carta será bem recebida e merecerá uma resposta. Uma vez que só se presenteia o que se ama, o professor gostaria que seu amor fosse também amado por aqueles aos quais ele o remete" (p. 140). Será que as professoras recebiam com a mesma intensidade o que estava oferecendo-lhes? Será que compreendiam a importância dos assuntos ali tratados? Tão subjetivo!

Dos presentes oferecidos, considero que o filme $A$ história das coisas possibilitou muitos momentos de reflexões. Confesso que fiquei apreensiva sobre como seria a receptividade das professoras sobre as questões trazidas pelo filme, inclusive o consumo, porém, para minha surpresa, ele esteve presente em quase todos os encontros seguintes.

Sobre o filme as professoras escreveram suas reflexões.

Diante dos fatos tratados no filme, entendo como indivíduo formador de opinião, tenho o compromisso de conscientizar e ampliar o conhecimento dos alunos diante dos recursos naturais e humanos na sociedade atual, com ênfase na reflexão de que as nossas ações têm impacto positivo ou negativo no meio ambiente e até mesmo na vida de outros indivíduos, que o simples fato de comprarmos algo pode desencadear uma série de danos ao ambiente.

Que é necessário entender que em muitos casos o que eu quero eu nem sempre preciso, que o que eu quero descartar tem um destino e nem sempre esse destino trará benefícios... diante dessas reflexões saber que o ambiente é causa e consequência, ou seja, todas as ações tem reações e se enxergar como sujeito ativo e transformador dentro desse processo. (Sandra, Diário de bordo)

A reflexão que fica é que:

$\mathrm{Eu}$ como ser crítico, sujeito transformador, formadora de opinião tenho a responsabilidade de levar/transmitir/conscientizar de que precisamos mudar hábitos, abrir horizontes para novos conhecimentos e aprofundar sobre o tema, pois vai muito além de plantar e se se preocupar somente no nossa ambiente limitado (casa, escola, comunidade)... 
Pude ampliar meu conhecimento e ter uma visão mais ampla percebendo que estamos envolvidos, a todo momento, nesse ciclo de transformação e que nossas ações terão impactos e isso pode ser a longo prazo... tudo está sincronizado e as ações pensadas ou ambiciosas vem ocasionando o desiquilíbrio ambiental. (Letícia, Diário de bordo)

Eu gosto de trabalhar sobre Educação em sala, para poder conscientizar as crianças do bem que podemos fazer para nós mesmos e para o planeta, pois as crianças de hoje serão o futuro, e se os jovens não conscientizarem do futuro, o planeta vai chegar a míngua. $\mathrm{O}$ ambiente e a educação para a realidade dos acontecimentos está lenta, a humanidade não tem noção que os recursos estão acabando e vai acabar com essa aceleração do consumo desenfreado. Falo sempre para economizar folhas, descartes de lixo, não só por causa do bolso, mas para frear o uso abundante da produção, com a utilização dos recursos da natureza.

O vídeo que foi visto, mostrando o início e o andamento da produção até chegar ao consumo, devia ser mostrado sempre, principalmente nas escolas, para ser repassado pelas crianças como aprendizado, uma realidade que quase ninguém sabe e nem imagina. Porque falar para ajudar o meio ambiente é fácil, difícil é mostrar o porquê.

A devastação está perdendo o controle por causa do consumismo humano, e algum dia isso terá que ser mostrado e de deixar claro que a não manutenção vai destruir tudo que foi dado de graça pra nós.

A poluição, tanto com lixo como com desinformação vai destruir. A evolução está sendo para destruir e não construir. (Marta, Diário de bordo)

Não compareci ao encontro do vídeo sobre o consumo, mas pelo que percebi, relatava o consumismo e a nossa participação nisso.

Eu tento me policiar ao máximo quanto as reais necessidades consumistas na minha vida, principalmente agora que tenho um filho pequeno e quero que ele cresça com consciência de sua presença e participação no mundo.

Apesar disso, é complicado ter essa sensibilização constantemente convivendo num mundo consumista e competitivo.

As interações diárias nos levam à obrigação em ter, conduzindo-nos à falsa satisfação social.

O homem, de uma forma geral, pouco ou quase nada, se preocupa com sua relação com a natureza e seus iguais. A mídia exalta a felicidade artificial constante em que o consumismo e o culto a padronização estética são regras.

Como educadora, muitas vezes me sinto preocupada com o mundo que está sendo projetado para meus educandos, infelizmente, de acordo com essas cobranças 
sociais atuais. Percebo que ser bem sucedido não vai depender da capacitação que se tenha e sim da aceitação e adequação aos padrões impostos. (Sara, Diário de bordo)

A meu ver, atualmente, a relação homem $\mathrm{x}$ meio ambiente está da pior maneira. $\mathrm{O}$ consumismo, desmatamento ilegal, queimadas provocadas, extinção de espécies de animais e vegetais, devido à ação do homem, poluição, gases tóxicos, tudo isso na maioria das vezes é provocado por atitudes sem pensar no amanhã. Nada na natureza é finito. Nossas ações serão refletidas no amanhã. Se cada um fizer sua parte, com certeza o meio entrará em equilíbrio ecológico. (Laura, Diário de bordo)

O exemplo do rádio 4,99 ela cita os países em que provavelmente foram explorados os recursos naturais como África, Iraque e China.

Eu já comprei muito na China, para mim e para minhas filhas e nunca me coloquei integrada nesse "sistema". Quem montou aquele brinquedo tão barato?

Nós não percebemos que para adquirirmos essas "coisas", os recursos naturais estão acabando, a mão de obra cada vez mais barata e aos poucos nós voltamos para a escravidão! Devemos pensar e começar a mudar as atitudes. Para melhorar o mundo do futuro do amanhã. (Carla, Diário de Bordo)

Impressionante como alguns minutos de filme podem gerar reflexões tão importantes! As professoras começaram a se sentir parte das questões ambientais! Que legal! Que linda essa construção! Claro que ainda seriam necessários muitos outros encontros para conhecer e aprofundar nessa temática, mas as reflexões delas já demonstravam uma abertura importante para o diálogo e novas construções de saberes!

Chegamos a um ponto comum, não era mais algo que Tâmia estava dizendo, mas algo que construímos juntas. Tivemos uma maior afinidade para conversar, os diálogos passaram a ser mais espontâneos, e percebemos a importância do ouvir.

Educação ambiental é muito maior e vai além de reciclar, poluir, é abrir a mente para nossas atitudes e estreitar laços com a reflexão de viver com hábitos sustentáveis. Desenvolver estratégias que possibilitem a pensar e intervir nos problemas de onde vivemos, atingir o maior número de pessoas e criar uma relação de respeito, sentimento, amor como o nosso planeta, estimular a sensibilidade dos nossos pequenos (alunos). Trazer a reflexão que somos parte e tudo está interligado. Pequenos atos refletem as grandes transformações! (Letícia, Diário de bordo) 
Hoje eu falei para eles, pros meus alunos bem assim... a gente está muito preocupado, vocês devem sempre estar ouvindo as pessoas falando, 'ah! Eu queria um mundo melhor!', mas não é o mundo que vai ficar melhor, eu falei para eles, o mundo já estava aqui, as árvores já estavam aqui, os animais, as plantas, a gente que foi mudando o mundo. Então, o mundo só está respondendo. Então, houve uma geração que não cuidou direito desse mundo e agora que precisa de vocês para serem melhores para o mundo! Não é o mundo que é ruim com a gente, a gente que tem que mudar as nossas atitudes e sermos melhores para o mundo, falei isso pra eles! (Sandra, depoimento no $4^{\circ}$ encontro, 09/06/2016)

Os diários foram entregues a mim no último encontro. Então pude perceber que nem todas aprofundaram suas reflexões por escrito. Muitas vezes o diário foi utilizado para descrever os encontros, fazer anotações. Entendi que isso faz parte do processo, escrever sobre o que pensamos ou sentimos nem sempre é uma tarefa fácil e vários fatores podem contribuir para isso: ou por não gostar de escrever ou por falta de hábito ou por falta de tempo. Entendo que esse consumismo que as professoras perceberam no filme também se aplica ao consumo do nosso tempo. Estamos sempre muito ocupadas, na escola temos diversos projetos acontecendo, ainda nem terminamos um projeto e já estamos planejando o próximo! Essa rotina nas escolas consome nosso tempo, retira de nós o tempo para o diálogo, para a reflexão, tão necessários para nós, professores!

Sobre essa rotina que vivenciamos na escola, sinto que muitas das nossas ações acabam sendo automáticas, restritas à criação de respostas prontas para questões e demandas que surgem no dia a dia escolar. E quantas ações e projetos nós produzimos, mas não conseguimos registrar ou refletir sobre eles!

Sobre a sua prática em EA, a professora Sara registrou uma das ações desenvolvidas com alunos da Educação Infantil,

Já elaborei um projeto com alunos de educação infantil sobre reciclagem. O trabalho partiu do interesse dos alunos, buscamos a conscientização dos envolvidos, como seres atuantes no meio ambiente para diminuição ao impacto do consumo diário sobre a quantidade de lixo. Pesquisamos a quantidade e o consumo de lixo diário da turma, o destino do lixo, a vida das famílias que sobrevivem da reciclagem, a importância da separação do lixo, visitamos uma recicladora de materiais de construção, pesquisamos cada tipo de lixo, fizemos separação, confeccionamos objetos com cada tipo de lixo, apresentamos uma encenação sobre 
o reconto de uma história, confeccionamos murais. Eu adorei o trabalho! (Sara, Diário de bordo)

Durante o encontro, o relato da professora foi mais detalhado que sua escrita, percebi que ao contar sua prática, a professora resgatou em sua memória aquele momento, tinha um brilho no seu olhar. As professoras que estavam ouvindo ficaram admiradas e fizeram perguntas sobre o desenvolvimento das ações. Refleti sobre a prática valiosa que nós, professores, temos e que muitas vezes não compartilhamos com os nossos colegas, e que no momento em que estamos desenvolvendo não percebemos a importância disso na vida de quem participa.

A professora Letícia, compartilhou oralmente sua experiência em um projeto sobre reciclagem e compostagem:

\footnotetext{
Sempre a gente está envolvido em algum projeto engajado com a questão ambiental. Eu lembro que ano passado, se eu não me engano foi sobre reciclagem, foi um projeto muito bacana, que a gente se envolveu muito e eles também. Foi a questão mesmo de reciclar, de diminuir os resíduos produzidos e tal, então teve oficinas, com o $4^{\circ}$ ano e foi algo bem bacana. Esse ano, a gente também trabalhou essa questão ambiental, preocupada com o meio ambiente, precisamente com o solo, que foi a construção da composteira, que foi algo também bacana. Eu acabei aprendendo coisas que de repente a gente acha que nem são tão importantes, mas são, né! Você leva pros meninos, então a gente acabou se envolvendo com o tema também. Então eu acho assim, que sempre, de formas diferentes, a gente está engajado nesse tema e preocupado sim com o MA! (Letícia, depoimento no $6^{\circ}$ encontro, 23/06/2016)
}

Nosso sétimo encontro foi bem marcante pra mim. Nele tivemos a oportunidade de refletir sobre nossa profissão, ser professora. Tivemos um momento para compartilhar nossas experiências, relembrando alguns professores que marcaram nossa trajetória estudantil e pensarmos sobre nossas expectativas enquanto educadoras.

Foi lindo! Mais uma vez tivemos um momento de identificação, relembramos nossas origens, rememorando professores que marcaram nossa trajetória escolar, nos emocionamos e naquele momento percebemos que também marcamos a vida dos nossos alunos. Compartilhamos, além das nossas histórias, nossos sentimentos. 
Acredito que a educação acontece em vários lugares e momentos e não se limita somente aos portões da escola. Na infância ocorreram situações em que eu tinha uma sensação de 'especial', 'aconchego' e 'carinho' com duas professoras, professora de dança e a tia Sara na $2^{\mathrm{a}}$ série. Várias coisas que ela ensinou até hoje me lembro e fizeram a diferença na minha vida. Qual educação que eu quero? Não quero a reprodutora e sim a transformadora. Que eu busque conhecimentos e que Deus me capacite também para os meus alunos. Que eu possa em algum momento plantar uma semente boa, seja para vida para amanhã e essa tenha efeito algo que eu ensine que o aprendizado seja significativo mesmo que mais conteudista.(Carla, Diário de bordo)

Essa identificação (com os professores) me fez ficar mais acessível, foi uma motivação para tentar compreender e achar interessante as aulas. Fui conquistada pelas relações de afetividade, foi essencial e estimulador para o progresso da aprendizagem.

Tenho o papel motivador responsável também pelo crescimento social/ intelectual/ afetivo/ emocional. Permitindo-os a imaginar, sonhar, deliberar, sonhar e descobrir com o intuito de permear seu mundo, com um olhar único e sensibilizador eu possa plantar a sementinha do bem. Levar para sua realidade/dentro de sua linguagem uma certeza que ele vai conseguir. Potencializar suas habilidades e valorizar seu progresso e suas descobertas e fazer do mundo deles um mundo mais alegre, colorido e leve (saber lidar com as frustrações em decorrência das expectativas)... (Letícia, Diário de bordo)

$\mathrm{Na}$ faculdade tive grandes professores, entre eles o professor Carlos Mota. Comecei a me identificar com o curso quando fiz a disciplina de Organização do Trabalho Pedagógico com ele. Neste, o trabalho final era um bordado que refletisse um trecho do livro do Paulo Freire "Pedagogia da Autonomia" que me tocasse em algum aspecto. Era encantador fugir aos padrões de seminários. E foi ali que escolhi tentar fazer a diferença na vida de alguém.

Lembro de um turma de $2^{\circ}$ ano. Me disseram apenas que desse continuidade e levasse como desse, que era uma turma difícil em conteúdo e comportamento, que eu não me frustrasse. Tinha realmente um aluno que me tirava do sério, comecei a utilizar calmante para conseguir lidar com aquela situação, mas enfim, refleti sobre os demais e a necessidade de um trabalho diferenciado. E foi o que eu fiz! Retomei o trabalho de forma mais lúdica, por meio de jogos, brincadeiras, dinâmicas, teatros de fantoche, histórias musicadas e carinho. Ao final, apenas três não progrediram tão satisfatoriamente, mas alcançaram muitas expectativas. E descobri a importância do olhar afetuoso. (Sara, Diário de bordo) 
Em nossa trajetória escolar, afetamos e somos afetados por nossos professores. Como professoras afetamos nossos alunos e, assim, percebemos o valor de construir aulas diferentes com possibilidades de nos aproximarmos de nossos alunos. Entendi que ao pensar em uma ação de formação para professoras, busquei nesse afeto a possibilidade de construir com elas um novo saber.

Ainda nesse encontro, pude compartilhar com elas as minhas inseguranças, como professora e pesquisadora, e como também estava sendo formada naqueles encontros. Nos identificamos nos medos, medo de não dar conta, medo de não conseguir, medo de não atingir os nossos objetivos. Compreendi que não somos completos, naquele momento, éramos professoras, alunas, mães e filhas, reconhecendo nossas incompletudes.

Como última tarefa, solicitei às professoras que fizessem uma avaliação, oral e por escrito, da nossa ação de formação. Ser avaliado é algo complexo, mas tentei ao máximo, mais uma vez, ouvir sem julgamentos.

Eu achei muito legal também a dinâmica do curso, como foi, como você falou a preocupação de levar algo mais... eu achei a dinâmica muito tranquila. É claro que no início a gente ficou meio preocupada, como será isso né? Como que vai ser cobrado? Mas pra mim, foi algo tão tranquilo e leve, que a gente foi construindo junto, essa troca facilita né, o entendimento, o processo, a construção. E eu achei muito bacana a dinâmica do curso e a gente também só tem agradecer à professora Tâmia, por ter vindo aqui e passar uma formação bacana e que a gente pode aproveitar muito. Muita coisa do que a gente viu aqui eu levo pra sala de aula, como conversa com eles, mesmo pra instigar, debater, algo sem muita cobrança, mas começa a plantar e daquilo ali você vai começando a colher, sabe assim, algo bem devagar mesmo. E foi algo como começou o curso, eu vim com uma expectativa, e ai me fez ir atrás, ler mais, porque a gente precisa, foi uma troca, foi uma ajudando a outra, você trazendo conhecimentos novos pra gente, coisas que a gente já trabalhava também e a gente acabou descobrindo que fazia esse tipo de incentivo em sala, os projetos da escola, pelo menos daqui, foram sempre envolvidos de alguma forma com esse tema, e pra mim foi super enriquecedor, foi bacana! (Letícia, depoimento no $7^{\circ}$ encontro, 28/06/2016)

Acho que é a dinâmica de como foi feito, como a Tâmia fez com a gente, quando falou em formação eu já imaginei aquele monte de texto pra ler em casa, falou em diário de bordo, eu pensei naquela pasta imensa com aquela reflexão complicadíssima, com coisas pra pesquisar fora... E assim, não teve isso, foi super tranquilo, os textos tranquilos... os filmes super gostosos de assistir, bacana de 
fazer. Eu ficava naquela, gente eu tenho coisa pra fazer, quando eu parava e sentava pra fazer eu via como era tranquilo de fazer, que nem esse último... quando eu sentei pra fazer foi tranquilo, foi a reflexão, foi meu trabalho, foi repensar. Então, eu acho que o que falta pros nossos alunos é isso, eu acho que não só EA, mas de uma forma geral é você trabalhar o conteúdo de uma forma mais tranquila porque não é forçando a cópia ou o exercício maçante ou aquela leitura imensa que vai gerar um conhecimento a mais, eu acho que o que gera um conhecimento a mais é a dinâmica que você trabalha é o marco que você faz na vida dele, como vai ficar marcado aquilo. Então é de uma forma tranquila, é um vídeo legal que ele vai assistir, ele não vai esquecer, então eu acho que o que falta é a gente pensar um trabalho, trabalhar o conteúdo sim, mas de uma forma diferente né, sem ser aquela coisa pra decorar, porque vai cair na prova... (Sara, depoimento no $7^{\circ}$ encontro, 28/06/2016)

O curso despertou grande curiosidade sobre as questões ambientais, trouxe documentos interessantes sobre o ambiente. Com o curso pude entender um pouco mais sobre a EA e discutirmos possibilidades para articular tais saberes entre as possibilidades do trabalho na sala de aula com as crianças. (Carla, Diário de bordo)

Em relação a credibilidade do curso, eu adorei! No primeiro dia, achei que seria leituras, estudos. Mas o desenvolvimento foi se mostrando dinâmico, agradável, bem realista e as demonstrações, a parte lúdica, muito construtivo e fácil de entender.

No meu entender, eu gostaria de mais horas aulas, pra aprofundar no conceito e no conhecimento de que é EA. No resumo eu adorei. Me abriu uma maior curiosidade sobre o assunto, já conhecido pra mim, mas agora portas e curiosidades se abriram. (Marta, Diário de bordo)

Mesmo com todos os desafios que enfrentei, me senti contemplada com a avaliação das professoras. Sei que não foi perfeito, não saímos prontas, mas com possibilidades de continuar no processo de formação.

Ao retornar à escola no dia 20 dezembro de 2016, percebi que algumas reflexões ecoavam em nós. Ao fazerem uma reflexão sobre o restante do ano após o curso, as professoras perceberam que as questões discutidas durante nossa ação de formação estavam presentes nos conteúdos trabalhados em sala, talvez não como foram organizados e pensados por elas no primeiro momento, mas se fizeram presentes nas aulas e também na suas vidas cotidianas. 
Pra mim, a reflexão que fica sempre agora depois de tudo aquilo que a gente viu, é claro que coisas que eu aprendi no curso, durante essa formação, o que mais me impressionou foi de onde as coisas vêm! E aí tudo o que sempre eu vou comprar agora eu fico de alguma forma, fico mais reflexiva, não que não vou comprar, mas você fica reflexiva, em relação a comprar coisas pra mim, além do custo, claro, vem por traz uma reflexão de tudo o que você aprendeu e de alguma forma eu tento trazer pra minha prática mesmo, no dia a dia! (Letícia, depoimento em 20/12/2016)

Essa questão desse vídeo, de onde as coisas vem, a História das coisas, eu mandei esse link pra centenas de pessoas, e aí depois disso eu fiquei super encanada com esse negócio de comprar as coisas sabe, quando eu vejo os meus alunos arrancando folha do caderno eu falo, gente vocês sabem de onde vem isso, menino?! Aquele vídeo me marcou muito [...] na minha casa, eu, posso falar isso bem... tinha um desperdício enorme de comida na minha casa e não tem mais, eu não aceito mais, eu comprava aquele monte de coisa, aí um monte de coisa eu jogava fora, sem brincadeira um monte de fruta, verdura, principalmente, estragava muito e agora eu compro só um pouquinho, só um pouquinho de cada coisa pra não ter o desperdício. Eu senti vergonha, eu fiquei com vergonha do que eu estava fazendo. Então assim, aquele vídeo mexeu demais comigo, eu acho que eu não sou mais a mesma pessoa depois daquele vídeo em relação a algumas coisas, eu não vou falar que eu mudei totalmente, porque infelizmente na sociedade que a gente vive e para o que a gente caminha, você acaba sendo levado pra tá ali nesse meio de consumo e tal... (Sandra, depoimento em 20/12/2016)

Muitas outras coisas ainda poderiam ser ditas nessa narrativa. Muitos depoimentos ainda poderiam ser descritos. Acredito que essa experiência não terminou, ainda estamos sendo formadas, como sujeitos da experiência, "algo como um território de passagem, algo como uma superfície sensível que aquilo que acontece afeta de algum modo, produz alguns afetos, inscreve algumas marcas, deixa alguns vestígios, alguns efeitos" (LARROSA, 2002, p. 24).

As palavras e considerações das professoras ainda ecoam dentro de mim. Não somos seres acabados, estamos em construção, todo dia gera um aprendizado. Nesse mestrado, não aprendi apenas os conhecimentos científicos ligados à temática ambiental, ele permitiu um conhecimento maior sobre 'eu professora', 'eu pesquisadora', 'eu aluna', 'eu social'.

A professora Marta nos presenteou com uma linda comparação sobre sala da aula e um jardim: 
Pela minha experiência já de tudo né, de idade, de sala, de tempo de mãe, de tudo... você tem que ver a sala de aula como um jardim. Num jardim você planta flores, trepadeiras, pé de manga, pé de couve, tem umas que morrem automaticamente, tem trepadeiras que sobrem, se alastram, que vão longe, tem flores que vão devagar... são coisas assim, não adianta ter frustração! Tem aqueles assim, as mudinhas, que você planta e os passarinhos já comem logo, você semeia... (Marta, depoimento no $7^{\circ}$ encontro, $\left.28 / 06 / 2016\right)$

Me imaginei em um jardim e entre elas eu também sou flor! Em um processo cíclico, ao ensinar eu também aprendo. Ao pesquisar também me pesquisei. Com a intensão de contribuir com a formação de colegas, fui formada. Esse foi um lindo motivo para nossa colcha de retalhos. Construímos uma proposta, não há acabamentos finais, mas possibilidades de continuidade, de novas técnicas, novos motivos, novas mãos! 


\title{
CAPÍTULO 6
}

\section{Possíveis alinhamentos e arremates}

\author{
Com agulha ou a máquina a costurar \\ Quilta-se o tecido, de forma livre ou regular \\ Prendem-se panos, mantas e velcro \\ Imita-se Deus na arte de criar \\ (Walter da Mata)
}

Ao tratarmos da confecção de colchas de retalhos, ainda que apresentem o mesmo objetivo, uma não será igual à outra. Uma das belezas que temos no artesanato é a múltipla variedade de formas, contornos e desenhos destinados a uma peça. Outro fator que garante a singularidade do artesanato é a experiência vivenciada durante o seu feitio, da mesma forma que transformamos um tecido em uma colcha, somos transformadas nesse processo, e podemos afirmar, que ao término da confecção não somos mais os mesmos.

Encontramos nesta pesquisa a possibilidade de refletir sobre dois grandes temas que participaram da minha formação e profissão docentes, a EA e a formação continuada de professores. A pesquisa colaborativa possibilitou o estudo e a confecção da nossa proposta de desenvolver uma ação de formação continuada de professores em EA para docentes dos Anos Iniciais, contribuindo para uma formação, dentro da escola, com um caráter crítico-reflexivo, pautada no diálogo, troca de experiências e trabalho colaborativo.

A formação continuada de professores e EA são temas constituintes na legislação brasileira e presentes no cotidiano escolar, muitas vezes manifestos nas práticas e projetos pedagógicos, entretanto, várias são as concepções, ênfases e sentidos atribuídos a esses temas.

Nossas perguntas de pesquisa nos motivaram a refletir sobre as diferentes abordagens, concepções de EA e de formação dos sujeitos e práticas pedagógicas relacionadas às questões que dizem respeito a EA e formação continuada de professores. Não pretendemos esgotar as discussões feitas com este trabalho, mas contribuir para um novo pensar sobre as relações que estabelecemos no ensino e na prática cotidiana.

Uma das nossas perguntas busca refletir sobre o entendimento das professoras a respeito da EA e como a relacionam com os currículos e projetos da escola. Os resultados apontam para três concepções que nós, professores, podemos ter sobre EA, a saber: concepção naturalizada, concepção cognoscitiva e concepção histórico-social. Percebemos que seria possível relacionar essas concepções com a prática pedagógica apresentadas pelas 
professoras em seus relatos, assim, observamos duas ênfases: ênfase comportamental e ênfase crítica.

A concepção naturalizada mostra uma preocupação das professoras quanto à conservação dos recursos naturais e um entendimento de que os comportamentos/ações levam a um futuro melhor ou à destruição total da natureza, não reconhecendo a interação social humana. Nessa perspectiva, a prática da EA se traduz no ensino de bons comportamentos com uma ênfase comportamentalista, priorizando ações individuais e não coletivas, que pouco considera as implicações dessas ações e as causas e efeitos relacionados ao modelo de desenvolvimento socioeconômico.

Outra concepção sobre EA apresentada é a cognoscitiva, que pressupõe que a correta transmissão de informações e conteúdos técnicos e científicos podem garantir um bom relacionamento dos seres humanos com a natureza. Nessa concepção, o acesso dos alunos a informações corretas sobre as questões ambientais os levaria a compreender a importância da conservação de um recurso natural. Ainda percebemos uma ênfase comportamental nas práticas pedagógicas relacionadas a essa concepção, sugerindo que a formação dos sujeitos está em um nível de consciência transitiva ingênua, não estimulando o processo reflexivo e pensamento complexo quanto às questões ambientais.

Há ainda, mesmo que de forma tímida, uma concepção sobre EA voltada para as preocupações com as relações existentes entre sociedade e natureza, considerando a possibilidade de reflexão quanto ao pensamento complexo e abertura para um novo saber. Nessa concepção, denominada de histórico-social, a prática pedagógica assume uma ênfase crítica em que, ainda que discretamente, há indícios de uma reflexão e discussão sobre a crise ambiental, a partir das construções históricas e sociais, suas complexidades e a construção do saber com abertura para o diálogo, buscando por uma nova racionalidade como princípio das relações socioambientais. A formação dos sujeitos se pauta pela transição de uma consciência ingênua para uma consciência crítica, permitindo assim o resgate do sujeito inserido em sua realidade e capaz de transformá-la.

As palavras consciência e conscientização, frequentemente usadas pelas professoras durante as entrevistas e a ação de formação, serviram de base para as reflexões quanto à formação dos sujeitos. Assim, entendemos que seu uso pode estar relacionado a dois entendimentos do processo de formação: como repasse de informação e como processo reflexivo. Compreendemos que para a formação crítica dos sujeitos em EA faz-se necessário 
superar a construção de uma consciência ingênua, na medida em que levamos em consideração o sujeito como ser capaz de tomar decisões.

Ao considerar a conscientização como processo reflexivo na formação dos sujeitos, buscamos uma EA que possibilite o reconhecimento do sujeito, não apenas no mundo, mas com o mundo. Seu reconhecimento, sobre as relações que estabelece com outros seres humanos e com a natureza, e sobre os processos históricos e culturais implicados nessas relações. Com isso, o que se busca é a formação de um sujeito capaz de intervir na realidade e transformá-la, abrindo-se para o diálogo, a reflexão e a possiblidade de construir novos saberes.

A prática pedagógica apresentada pelas professoras no decorrer da ação de formação nos oferece indícios de uma possível construção de projetos que trabalhem na perspectiva de uma EA crítica, rompendo com a lógica do conhecimento-regulação, que fragmenta e objetifica a natureza. O trabalho desta EA é interdisciplinar, fundamenta-se pelo pensamento complexo e aponta para a construção de um novo saber, pautado pela responsabilidade com o próximo, por uma ética ecológica e por novos valores sociais.

Para responder como as professoras se preparam para trabalhar EA com os alunos, procuramos investigar seu entendimento sobre a formação continuada de professores. Assim, foi possível discutir a partir de três categorias, a saber: formação como capacitação ou instrumentalização, formação como atualização ou aquisição de informação e formação como relação entre teoria e prática docente.

Entendemos que para a formação continuada de professores em EA é importante superar a ideia de formação como instrumentalização, ou seja, que esta não esteja pautada no repasse de informações que auxiliem mecanicamente a realização da prática. A proposta é a formação de profissionais capazes de refletir sobre a prática, não somente dentro da escola, mas em conjunto com a realidade social onde estão inseridos.

A capacitação do professor em EA se dá por meio de uma reflexão sobre sua prática, conectando a busca por novas abordagens metodológicas à abertura de caminhos para um novo pensar, superando a visão tradicional de transmissão de conteúdos para uma visão em que há possiblidades de diálogos com as diferentes formas de pensar e agir sobre o contexto socialcultural e ambiental. Uma prática que não reduz essas relações a uma racionalidade técnica, mas busque por sua reconfiguração.

Entendemos a necessidade de formação continuada baseada numa perspectiva da práxis, em que teoria e prática se manifestam na ação docente, na formação cidadã de sujeitos 
situados em uma sociedade, capazes de tomar decisões conscientes e críticas. Compreendemos, então, a importância da formação continuada dos professores estar pautada numa prática reflexiva, na qual há possibilidades de auto-avaliação crítica para a sua formação, embasando sua prática e fortalecendo o caráter profissional da docência.

Entendemos assim, que esta pesquisa contribui com o campo da EA na formação dos professores, considerando suas relações com a formação dos sujeitos a partir de conteúdos curriculares.

Conforme mencionamos no início deste capítulo, ao compararmos nossa pesquisa a uma confecção artesanal entendemos a singularidade desse feitio, bem como as transformações que ocorrem, tanto no produto desenvolvido como no artesão que o manipula. Nesse caso, como artesã, compreendo que fui modificada durante a construção desse projeto. Assim, nesse processo de formação, fiz o uso das narrativas para descrever algumas de minhas reflexões.

Enquanto professora, também me formei. A escola como espaço de formação continuada permitiu um olhar diferenciado para as relações que tenho com os docentes e para minha prática pedagógica. Mesmo sendo um processo importante, a reflexão sobre a prática e a busca por construção coletiva não estão presentes em nossa cultura docente. Compreendi que no processo de formação é importante o protagonismo do sujeito que está em formação, seja professor ou estudante. É possível uma formação pautada no diálogo, na reflexão, nas experiências e nos processos de escuta.

A ação de formação desenvolvida permitiu ampliar os conhecimentos sobre os saberes docentes, a importância da reflexão crítica sobre a prática e o compartilhamento das experiências com os meus pares, podendo ser traduzida na minha prática pedagógica com meus alunos.

Como pesquisadora, entendi que o uso das narrativas, através dos diários de bordo utilizados pelas professoras, reforçam a necessidade de se pensar uma formação continuada que possibilite e estimule a reflexão como processo formador, que abra espaços permanentes de formação e que possibilite uma discussão e reconhecimento do profissionalismo docente.

Considerando o potencial reflexivo e formativo das narrativas autobiográficas, durante a ação de formação buscamos valorizar as reflexões e o caráter subjetivo das narrativas. Ressaltamos, portanto, a importância do uso desse método no processo de formação continuada, proporcionando momentos de reflexão individual e coletiva, abrindo 
espaços de escuta à voz dos professores e ampliando a possibilidade de serem protagonistas da sua própria formação.

Nosso intuito com este artesanato, não é entregar uma peça pronta e acabada, mas possibilitar sua construção e reconstrução. Pensar e repensar sobre nossas práticas e percepções em EA e formação continuada de professores, com objetivo de resgatar uma educação que valorize os sujeitos, permitindo que conheçam e reconheçam sua relação com o ambiente onde estão inseridos e, através de uma educação que promova uma consciência crítica, sejam capazes de modificá-lo. 


\section{REFERÊNCIAS BIBLIOGRÁFICAS}

ALMEIDA, M. C. Complexidade, saberes científicos, saberes da tradição. São Paulo, Editora Livraria da Física, 2010.

ALMEIDA, M.I. de (org). Formação Contínua de Professores. MEC. Boletim 13. 2005.

ALMEIDA, M.I. de. Formação contínua de professores em face das múltiplas possibilidades e dos números de parceiros existentes hoje. In: ALMEIDA, M.I. de (org). Formação

Contínua de Professores. MEC. Boletim 13. 2005. p. 11-17.

ARROYO, M. Ciclos de Desenvolvimento Humano e Formação de Educadores. Educação e Sociedade. Ano XX. Número 68. Dezembro. 1999. Disponível em:

<http://www.scielo.br/pdf/es/v20n68/a08v2068.pdf> Acesso em: 22 out. 2015.

BANDEIRA, H. M. M. Formação de professores e prática reflexiva. 2006. Disponível em: <http://www.ufpi.br/subsiteFiles/ppged/arquivos/files/eventos/2006.gt1/GT1_13_2006.PDF> Acesso em: 01 jun. 2015.

BOGDAN, R. C.; BIKLEN, S. K. Investigação qualitativa em educação: uma introdução à teoria e aos métodos. Portugal: Porto Editora, 1994.

BRASIL. Ministério da Educação. Diretrizes Curriculares Nacionais Gerais da Educação Básica. Brasília: MEC, SEB, DICEI, 2013.

BRASIL. Ministério da Educação e do Desporto. Lei 9.394 de 20 de Dezembro de 1996. Lei de Diretrizes e Bases da Educação Nacional, Brasília, 1996.

BRASIL. Constituição (1988). Constituição da República Federativa do Brasil: promulgada em 5 de outubro de 1988. Disponível em

<http://www.planalto.gov.br/ccivil_03/constituicao/ConstituicaoCompilado.htm> Acesso em 17 jan. 2016.

BRASIL. Lei n 9795, de 27 de abril de 1999. Dispõe sobre a educação ambiental, institui a Política Nacional de Educação Ambiental e dá outras providências. Disponível em <http://portal.mec.gov.br/secad/arquivos/pdf/educacaoambiental/lei9795.pdf> Acesso em: 17 jan. 2016.

BRASIL. Lei n 9985, de 18 de julho de 2000. Regulamenta o art. 225, § 1ํㅡ, incisos I, II, III e VII da Constituição Federal, institui o Sistema Nacional de Unidades de Conservação da Natureza e dá outras providências. Disponível em <http://www.mma.gov.br/port/conama/legiabre.cfm?codlegi=322> Acesso em: 12 jan. 2017.

BRASIL. Política Nacional de Educação Especial na Perspectiva da Educação Inclusiva, Brasília 2008. Disponível em

$<$ http://portal.mec.gov.br/index.php?option=com_docman\&view=download\&alias=16690politica-nacional-de-educacao-especial-na-perspectiva-da-educacao-inclusiva05122014\&Itemid=30192> Acesso em: 08 mar. 2017. 
BRASIL. Decreto n 5773, de 9 de maio de 2006. Dispõe sobre o exercício das funções de regulação, supervisão e avaliação de instituições de educação superior e cursos superiores de graduação e sequencias no sistema federal de ensino. Disponível em <http://www.planalto.gov.br/ccivil_03/_ato2004-2006/2006/decreto/d5773.htm> Acesso em: 17 jan. 2016

BRASIL, MMA. Educação ambiental no Brasil. Salto para o Futuro. Ano XVIII, boletim 01, março. 2008

BUENO, B.O. O método autobiográfico e os estudos com histórias de vida de professores: a questão da subjetividade. Educação e Pesquisa, São Paulo, vol. 28, n. 01, p. 11-30, janjunho. 2002. Disponível em <http://www.scielo.br/pdf/ep/v28n1/11653.pdf> Acesso em: 05 abr. 2016.

BUENO, B.O et al. Histórias de vida e autobiografias na formação de professores e profissão docente. Educação e Pesquisa. São Paulo, vol. 32, n. 2, p. 385-410, maio-ago. 2006.

Disponível em <http://www.scielo.br/pdf/ep/v32n2/a13v32n2.pdf> Acesso em: 20 abr. 2016.

CARVALHO, I.C. de M. Educação ambiental crítica: nomes e endereçamentos da educação. In: LAYRARGUES, P.P (org.) Identidades da Educação Ambiental Brasileira. Brasília, MMA, 2004.

CARVALHO, I.C.de M. Educação ambiental: a formação do sujeito ecológico. São Paulo: Cortez, 2004.

CAVALCANTI, D.B., COSTA, M.A.F.; CHRISPINO, A. Educação Ambiental e Movimento CTS, caminhos para a contextualização do Ensino de Biologia. Revista Praxis. Ano VI. n. 12. p. 27-42. dez. 2014. Disponível em < http://web.unifoa.edu.br/praxis/numeros/12/2742.pdf> Acesso em: 19 jun. 2015.

DESGAGNÉ, S. O conceito de pesquisa colaborativa: a ideia de uma aproximação entre pesquisadores universitários e professores práticos. Revista Educação em Questão, Natal, v.29. n. 15, p. 7-35, maio/ago 2007. Disponível em

<http://www.periodicos.ufrn.br/educacaoemquestao/article/view/4443/3629> Acesso em: 23 fev. 2016.

Dicionário Web

$<$ https://www.google.com.br/search?q=artigos+sobre+educa\%C3\%A7\%C3\%A3o\&oq=artigo s+sobre+educa\% $\% 3 \%$ A7\% C3\% A3o\&aqs $=$ chrome..69i57j015.5322j0j7\&sourceid=chrome\&e s_sm=93\&ie $=$ UTF-8\#q=o+que+\%C3\%A9+educa\%C3\%A7\%C3\%A3o $>$ Acesso em: 11 nov. 2015.

FERNANDES, Francisco. Dicionário Brasileiro Globo. ed. 50. São Paulo:Globo, 1998.

FERRAROTTI, F. Sobre a autonomia do método biográfico. In: NÓVOA, A \& FINGER, M. (orgs). O método (auto)biográfico e a formação. Natal, RN: EDURFN, São Paulo: Paulos, 2010. 
FRANCO, M. L. P. B. Análise de conteúdo. 4 ed. Brasília: Liber Livro, 2012.

FREIRE, P. Educação como prática da liberdade. RJ: Editora Paz e Terra LTDA. 1967.

FREIRE, P. Conscientização: teoria e prática da libertação, uma introdução ao pensamento de Paulo Freire. São Paulo: Cortez \& Moraes. 1979.

FREIRE, P. Educação e mudança. 12.ed. Paz e Terra. 1980.

GASTAL, M. L.; AVANZI, M. R. Da razão que liberta à experiência que dá sentido: inquietações sobre educação ambiental, sexual e para saúde numa escola plural. In: Roberto Dalmo V. L. Oliveira; Glória Regina P. C. Queiroz (org.). Tecendo diálogos sobre direitos humanos na educação em ciências. 1ª ed. São Paulo: Livraria da Física. p. 215-233. 2016.

GHEDIN, E. Professor Reflexivo: da alienação da técnica à autonomia da crítica. In: PIMENTA, S.G. \& GHEDIN, E. (orgs). Professor reflexivo no Brasil: gênese e crítica de um conceito. 5. ed. São Paulo: Cortez, 2008.

GRUN, M. Ética e educação ambiental: A conexão necessária. 3 ed. Campinas, SP: Papirus. 2000.

IMBERNÓN, F. Formação permanente do professorado: novas tendências/Francisco Imbernón tradução de Sandra Trabucco Velenzuela. São Paulo: Cortez, 2009.

IMBERNÓN, F. Formação docente e profissional: formar-se para a mudança e a incerteza/ Francisco Imbernón tradução de Silvana Cobucci Leite. 9 ed. São Paulo: Cortez, 2011.

JOSSO, M. C. Da formação ao sujeito... ao sujeito da formação. In: NÓVOA, A \& FINGER, M. (orgs). $O$ método (auto)biográfico e a formação. Natal, RN: EDURFN, São Paulo: Paulos, 2010.

LARROSA, J. Notas sobre a experiência e o saber de experiência. Revista Brasileira de Educação. n. 19, p. 20-28, 2002. Disponível em

<http://www.scielo.br/pdf/rbedu/n19/n19a02.pdf> Acesso em: 14 jun. 2016.

LARROSA, J. Sobre a lição: ou do ensinar e do aprender na amizade e na liberdade. In: Pedagogia profana: dança, piruetas e máscaras. Editora Autêntica. p. 139-146. 2010.

LARROSA, J. Experiência e alteridade em educação. Reflexão \& Ação, Santa Cruz do Sul, v. 19, p. 4-27, 2011. Disponível em <file:///C:/Users/Tamia/Downloads/2444-9901-1PB.pdf> Acesso em: 07 maio 2016.

Legislação brasileira sobre educação [recurso eletrônico]. - 2. ed. - Brasília: Câmara dos Deputados, Edições Câmara, 2013. 358 p. - (Série legislação; n. 94).

LEFF, E. Saber Ambiental: sustentabilidade, racionalidade, complexidade, poder /Enrique Leff; tradução de Lúcia Mathilde Endlich Orth. 10 ed. Petrópolis, RJ: Vozes, 2013. 
LIBÂNEO, J. C. Reflexividade e formação de professores: outra oscilação do pensamento pedagógico brasileiro? In: PIMENTA, S.G. \& GHEDIN, E. (orgs). Professor reflexivo no Brasil: gênese e crítica de um conceito. 5. ed. São Paulo: Cortez, 2008.

LUDKE, M. \& ANDRÉ, M.E.D.A. Pesquisa em Educação: abordagens qualitativas. São Paulo: EPU. 1986.

MINAYO, C. S. Pesquisa Social: teoria, método e criatividade. 28. ed. Petrópolis, RJ: Vozes, 2009.

MORIN, E. A cabeça bem-feita: repensar a reforma, reformar o pensamento/Edgar Morin; tradução Eloá Jacobina. 22. ed. RJ: Bertrand Brasil, 2015.

MORIN, E. A necessidade de um pensamento complexo. In: MENDES, C. (org) \& LARRETA, E. (ed.). Representação e complexidade. Rio de Janeiro: Garamond, 2003.

NÓVOA, A. Formação de professores e profissão docente. 1992. Disponível em: $<$ https://docs.di.fc.ul.pt/bitstream/10451/4758/1/FPPD_A_Novoa.pdf> Acesso em: 06 jan. 2016.

NÓVOA, A. (Org). Vida de professores. 2. ed. Porto: Porto Editora, 2007.

PENTEADO, H. D. Meio Ambiente e formação de professores. São Paulo: Cortez, 1994.

PEQUENO, M. Sujeito, autonomia e moral. In: TOSI, G. (ed). Direitos Humanos: história, teoria e prática. Editora Universitária UFPB: João Pessoa, 2007.

PERNAMBUCO, M.M.C. \& SILVA, A.F.G. Paulo Freire: a educação e a transformação do mundo. In: Carvalho, I.C.M.; Grun, M.; Trajber, R. (orgs.) Pensar o ambiente: bases Filosóficas da Educação Ambiental. Brasília, MEC, p.199-212. 2004

PIMENTA, S.G. \& GHEDIN, E. (orgs). Professor reflexivo no Brasil: gênese e crítica de um conceito. 5. ed. São Paulo: Cortez, 2008.

ROLDÃO, M. C. Função docente: natureza e construção do conhecimento profissional. Revista Brasileira de Educação. v. 12, n. 34, p. 94-103, jan/abril, 2007. Disponível em <http://www.scielo.br/pdf/rbedu/v12n34/a08v1234.pdf > Acesso em: 04 out. 2016.

SANTOS, B. de S. Para um novo senso comum: a ciência, o direito e a política na transição paradigmática. v. 1, 3. ed. São Paulo: Cortez, 2001.

SANTOS, R.S.S. dos. Olhares a respeito da Educação Ambiental no currículo de formação inicial de professores. 2015. 280 f. Tese (Doutorado em Educação). Universidade de Brasília, Brasília, 2015.

SANTOS, W.L.P. et al. O enfoque CTS e a Educação Ambiental: Possibilidade de "ambientalização" da sala de aula de Ciências. In: SANTOS, W.L.P.; MALDANER, O.A. (org). Ensino de Química em Foco. Ijuí: Ed. Inijuí, p. 129-157, 2010. 
SAVIANI, D. Formação de professores: aspectos históricos e teóricos do problema no contexto brasileiro. Revista Brasileira de Educação, v. 14, n. 40, p. 143-155, jan/abril. 2009. Disponível em <http://www.scielo.br/pdf/rbedu/v14n40/v14n40a12.pdf > Acesso em: 02 jun. 2015.

SEGURA, D. S. B. Educação ambiental nos projetos transversais. In: MELLO, S.S. e TRAJBER, R (coord). Vamos cuidar do Brasil: conceitos e práticas em educação ambiental na escola. Brasília: Ministério da Educação, Coordenação Geral de Educação Ambiental: Ministério do Meio Ambiente, Departamento de Educação Ambiental: UNESCO, 2007.

SILVA, K.A.C.P.C da. A formação de professores na perspectiva crítico-emancipadora. Linhas Críticas. Brasília, DF. v. 17, n. 32, p. 13-31, jan/abril, 2011. Disponível em <http://repositorio.unb.br/bitstream/10482/9461/1/ARTIGO_FormacaoProfessoresPerspectiv a.pdf> Acesso em: 30 set. 2016.

TARDIF, M. Saberes docentes e formação profissional. 13. ed. Petrópolis/ RJ: Vozes, 2012.

TRISTÃO, M. A Educação Ambiental na formação de professores: redes de saberes. São Paulo: Annablume, Vitória: Facitec, 2004.

TRISTÃO, M. Tecendo os fios da educação ambiental: o subjetivo, o pensado e o vivido. Educação e Pesquisa. São Paulo, v. 31, n. 2, p. 251-264, maio/agosto, 2005. Disponível em <http://www.scielo.br/pdf/ep/v31n2/a08v31n2.pdf> Acesso em: 07 jun. 2016.

TANNOUS, S.; GARCIA, A. Histórico e evolução da Educação Ambiental, através dos tratados internacionais sobre o meio ambiente. Nucleos, v. 5, n.2, p. 183-195. out. 2008. Disponível em <http://www.researchgate.net/publication/45146201_HISTRICO_E_EVOLUO_DA_EDUC AO_AMBIENTAL_ATRAVS_DOS_TRATADOS_INTERNACIONAIS_SOBRE_O_MEIO _AMBIENTE> Acesso em: 27 maio 2015.

TOZONI-REIS, M.F.C. Formação dos educadores ambientais e paradigmas em transição. Ciências e Educação, v. 8, n. 1, p.83-96. Disponível em <http://www.scielo.br/pdf/ciedu/v8n1/07.pdf> Acesso em: 02 jul. 2015.

TOZONI-REIS, M. F. C. Educação Ambiental: natureza, razão e história. Campinas, SP. ed. Autores Associados, 2004.

WEFFORT, F. C. Educação e política: reflexões sociológicas sobre uma pedagogia da Liberdade. In: FREIRE, P. Educação como prática da liberdade. RJ: Editora Paz e Terra LTDA. 1967. 


\section{APÊNDICES}

\section{APÊNDICE 1 - TCLE}

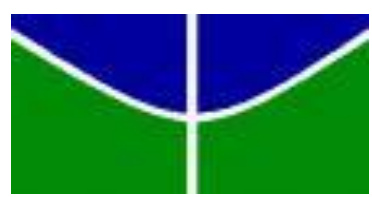

\section{UNIVERSIDADE DE BRASÍLIA}

\section{PROGRAMA DE PÓS-GRADUAÇÃO EM ENSINO DE CIÊNCIAS}

\section{TERMO DE CONSENTIMENTO LIVRE E ESCLARECIDO}

Este é um convite para participar, como voluntário (a), de um curso de formação continuada em Educação Ambiental, que será realizada pela mestranda Tâmia Teles, sob a orientação da $\operatorname{Prof}^{a} \operatorname{Dr}^{a}$ Maria Rita Avanzi do Núcleo de Educação Científica (NECBIO)/IB - UnB.

O objetivo desta pesquisa-ação é contribuir com a formação continuada de professores em Educação Ambiental (EA) que possibilite uma reflexão a respeito de suas concepções sobre EA e uma busca por caminhos de transformação de sua prática pedagógica, fortalecendo a escola como um espaço para formação cidadã, trabalho coletivo e profissionalização docente.

As informações obtidas nesta pesquisa serão utilizadas na produção de conhecimentos na área de formação de professores e Educação Ambiental. Serão utilizadas somente para fins acadêmicos e, no caso de serem citadas em artigos e trabalhos científicos, o nome dos informantes será mantido em anonimato.

A pesquisa não trará riscos a integridade física, moral e mental.

É possível a desistência da sua participação, a qualquer momento, sem nenhuma consequência da formação. Solicitamos que, neste caso, você entre em contato e informe à pesquisadora. $\mathrm{Eu}$, declaro ter sido esclarecido (a) sobre os pontos acima descritos e assumo livremente este termo de consentimento.

Brasília, de de 2016.

Assinatura:

$\mathrm{Eu}$, expliquei a (o) a proposta desta formação e os procedimentos do estudo.

Brasília, de de 2016.

Assinatura:

Professora-pesquisadora: Tâmia Teles e-mail:tamikis@gmail.com

Tel: 8209-2966

Orientadora: Profa. Dra. Maria Rita Avanzi Email:mariarita@unb.br PPGEC/UnB: www.ppgec.unb.br 


\section{APÊNDICE 2 - AÇÃO DE FORMAÇÃ̃ - Planejamento inicial}

\begin{tabular}{|c|c|}
\hline Universidade de Brasilia - UnB & $\begin{array}{c}\text { UNIVERSIDADE DE BRASÍLIA } \\
\text { Institutos de Biologia, Física e Química } \\
\text { Programa de Pós-Graduação em Ensino de Ciências } \\
\text { Mestrado profissional em Ensino de Ciências }\end{array}$ \\
\hline & PLANO DE AÇÃO \\
\hline \begin{tabular}{l|l} 
Centro: & $\mathrm{C}$ \\
\end{tabular} & entro de Ensino Fundamental 115 - Recanto das Emas \\
\hline Curso: & Formação de professores em Educação Ambiental \\
\hline Professor(a): & Tâmia Teles/ Maria Rita Avanzi \\
\hline Horário & Quintas-feiras às 13:30 \\
\hline \multicolumn{2}{|l|}{ 1. Ementa } \\
\hline $\begin{array}{l}\text { Trata-se de un } \\
\text { realizado no C } \\
\text { Distrito Federa } \\
\text { pedagógica ref } \\
\text { profissionalizaç } \\
\text { para diálogo e } \\
\text { escolar. }\end{array}$ & $\begin{array}{l}\text { n curso de formação continuada para professores em Educação Ambiental que será } \\
\text { entro de Ensino Fundamental } 115 \text { do Recanto das Emas da Secretaria de Educação do } \\
\text { 1. O curso tem como objetivo auxiliar os profissionais que já estão inseridos na prática } \\
\text { letirem sobre a prática docente e a Educação Ambiental, contribuindo para a sua } \\
\text { ão e formação crítica dos educandos. Terá o formato de grupo de estudos, com espaço } \\
\text { reflexão, assim como propostas para aplicação da Educação Ambiental no contexto }\end{array}$ \\
\hline
\end{tabular}

\section{Objetivo Geral:}

Contribuir para a formação continuada em Educação Ambiental de professores dos anos iniciais da educação fundamental da Secretaria de Educação do DF, por meio de uma ação piloto a ser desenvolvida no Centro de Ensino Fundamental 115 do Recanto das Emas.

\section{Objetivos Específicos:}

- refletir sobre o papel da escola na formação coletiva, em uma perspectiva colaborativa e participativa;

- incorporar uma postura dialógica e reflexiva em sua prática docente;

- desenvolver uma autonomia na busca de um arcabouço teórico e metodológico a respeito da EA;

- contribuir para a formação do sujeito ecológico;

- construir propostas de ações de EA para o ambiente escolar que visem o fortalecimento do Projeto Político Pedagógico. 


\begin{tabular}{|c|c|c|}
\hline Universidade de Brasilia - UnB & \multicolumn{2}{|l|}{$\begin{array}{c}\text { UNIVERSIDADE DE BRASÍLIA } \\
\text { Institutos de Biologia, Física e Química } \\
\text { Programa de Pós-Graduação em Ensino de Ciências } \\
\text { Mestrado profissional em Ensino de Ciências }\end{array}$} \\
\hline \multicolumn{3}{|l|}{ 4. Encontros: } \\
\hline & Encontros & $\mathrm{C} / \mathrm{H}$ \\
\hline $\begin{array}{l}\text { Encontro 1-Ap } \\
\text { quanto à educaçã } \\
\text {. Reflexão indivi } \\
\text { 1. O que é } \\
\text { 2. Porque e } \\
\text { 3. Qual a v } \\
\text {. Construção do } \\
\text { questões propost } \\
\text { Horas compleme } \\
\text {. Solicitar leitura } \\
\text { Nacional de Edu } \\
\text { para sociedades } \\
\text { disponibilizados }\end{array}$ & $\begin{array}{l}\text { roposta e formação do grupo de estudo: reflexão } \\
\text { ompartilhamento de saberes } \\
\text { e coletiva à cerca da EA, a partir das perguntas: } \\
\text { ar a EA na escola? } \\
\text { obre ambiente? } \\
\text { s para montagem de painel coletivo a respeito das } \\
\text { oficiais sobre EA - Declaração de Tbilisi, Política } \\
\text { l(Lei } 9795 / 99 \text { ) e Tratado de Educação Ambiental } \\
\text { sponsabilidade global. Os textos serão } \\
\text { upo via Facebook. }\end{array}$ & $2 \mathrm{~h}$ \\
\hline $\begin{array}{l}\text { Encontro 2-I } \\
\text { cerca da históri } \\
\text {. A partir de leitı } \\
\text { documentos ofic } \\
\text {. Discussões em } \\
\text {. Construção do } \\
\text {. Conversar sobr } \\
\text { pra que eles serv } \\
\text {. Relacionar os d } \\
\text { Horas compleme } \\
\text {. Solicitar leitura } \\
\text { Facebook. } \\
\text {. Assistir aos filn } \\
\text { existentes entre I }\end{array}$ & $\begin{array}{l}\text { trabalho coletivo e construção do conhecimento a } \\
\text { a EA. } \\
\text { ponibilizadas no grupo do Facebook), refletir sobre os } \\
\text { sobre os objetivos e princípios da EA. } \\
\text { ivo. } \\
\text { ra montagem do painel. } \\
\text { s objetivos foram estabelecidos? em qual contexto? } \\
\text { a prática pedagógica: é possível? } \\
\text { sobre a Crise Ambiental disponibilizada no grupo do } \\
\text { mo Treinar seu Dragão e refletir sobre as relações } \\
\text { nos e Humanos-Natureza }\end{array}$ & $3 \mathrm{~h}$ \\
\hline $\begin{array}{r}\text { Encontro 3-En } \\
\text { \# Iniciar re } \\
\text {. Apresentar o fil } \\
\text { Refletir individ } \\
\text { a) Eu com } \\
\text { b) Eu nisso } \\
\text {. Relembrar o fil } \\
\text { questões da unid } \\
\text {. A partir de frag } \\
\text { Humanos-Huma } \\
\text {. Registro no diá }\end{array}$ & $\begin{array}{l}\text { sobre crise ambiental } \\
\text { Crise Ambiental } \\
\text { das coisas } \\
\text { car no diário: } \\
\text { idos e propor discussão e reflexão no grupo sobre as } \\
\text { nstrução das fichas coletivas. } \\
\text { es proporcionar uma reflexão a cerca das relações } \\
\text {-Natureza }\end{array}$ & $3 \mathrm{~h}$ \\
\hline
\end{tabular}


Encontro 4 - Avaliar e repensar nosso plano de ação

. Apresentação do projeto Formação continuada de professores: uma pesquisa

colaborativa sobre EA com docentes de anos iniciais do ensino fundamental

- Avaliação do plano de ação - propostas e encaminhamentos

. Conversa sobre a Crise Ambiental e Educação Ambiental Crítica: busca por uma nova racionalidade

Encontro 5 - Leituras sobre o "ambiente".

. Refletir sobre: O que é ambiente a partir da observação de imagens que retratam

ambientes urbanos, rurais, conservados, etc.

- Compartilhar as percepções para o grupo: Porque eu escolhi esta(s) imagem(s)?

. Construir coletivamente o conceito de Meio Ambiente

Horas complementares:

. Registrar no diário reflexões quanto aos projetos ligados a EA que já participaram:
a) Já trabalhei com projetos de EA?
b) Como eles foram desenvolvidos?
c) Como me senti durante a realização?
d) O que percebo ser o ambiente dentro dos projetos que desenvolvi?

Encontro 6 - Formação do sujeito ecológico e prática pedagógica

. Compartilhar as experiências escritas pelas professoras no diário de bordo (atividade relativa às horas complementares do $5^{\circ}$ encontro).

. Retomar as fichas elaboradas coletivamente nos primeiros encontros e refletir sobre os objetivos da Educação e EA crítica na formação do sujeito, valorizando a formação do sujeito ecológico e do educador ambiental.

. Reflexão sobre a prática pedagógica: EA e projetos da escola

Horas complementares:

. Elaboração coletiva de um plano de ação utilizando a EA como eixo transversal nos projetos do $3^{\circ}$ e $4^{\circ}$ bimestre conforme PPP

. Registrar no diário de bordo, reflexões sobre o papel do professor na formação de

valores, atitudes e comportamentos dos alunos, a partir das perguntas:

4. Você, em sua trajetória como aluno(a), identifica situações em que se sentiu fortemente identificado(a) com um professor e seus ideais?

5. Lembra outras situações em que, a despeito das expectativas, privilegiou caminhos, decisões e intuições diferentes das que você acreditava serem as esperadas?

6. Enquanto educador(a), como você se sente a respeito de seus alunos? Quais

são suas expectativas em relação a eles e suas futuras escolhas?

*Atividade extraída do livro: Educação Ambiental: a formação do sujeito ecológico

(CARVALHO, 2004)

Encontro 7 - Oficina: Compartilhando saberes

. Compartilhar as experiências descritas no diário de bordo (atividade relativa as horas complementares do $6^{\circ}$ encontro).

. Compartilhar plano de ação desenvolvido coletivamente utilizando a EA como eixo transversal.

. Refletir sobre o papel do professor na formação dos alunos - Educador Ambiental

- Refletir sobre a importância da formação continuada de professores em EA

. Avaliação dos encontros e considerações finais 


\section{UNIVERSIDADE DE BRASÍLIA \\ Institutos de Biologia, Física e Química}

Programa de Pós-Graduação em Ensino de Ciências

Mestrado profissional em Ensino de Ciências

\section{Procedimentos Metodológicos:}

\section{. Diário de bordo}

As professoras serão motivadas a refletirem sobre as questões propostas no curso buscando atribuir a suas experiências e saberes.

. Fichas

Após discussão em duplas, os participantes escreverão em fichas suas reflexões sobre os questionamentos colocados durante o curso. Tem como objetivo o trabalho coletivo e diálogo, contribuindo para a formação do sujeito.

. Montagem do painel

Trabalho coletivo, conhecer a proposta e realidade do outro como instrumento para a formação, além de proporcionar reflexão individual, o pertencimento ao grupo (ser ouvido e ouvir).

\section{Recursos Didáticos}

. Uso dos grupos do Facebook para desenvolvimento das atividades de educação a distânica.

. Data-show

. Vídeos

. Músicas

. Textos

\section{Avaliação}

. Frequência

- Construção dos diários de bordo

. Comunicação oral

. Participação das atividades propostas

. Avaliação participativa ao longo dos encontros

\section{Referência Biliográfica}

BRASIL. Lei n 9795, de 27 de abril de 1999. Dispõe sobre a educação ambiental, institui a Política Nacional de Educação Ambiental e dá outras providências. Disponível em $<$ http://portal.mec.gov.br/secad/arquivos/pdf/educacaoambiental/lei9795.pdf> Acessado em 17/01/2016.

CARVALHO, I.C.de M. Educação ambiental: a formação do sujeito ecológico. São Paulo: Cortez, 2004.

IMBERNÓN, F. Formação permanente do professorado: novas tendências/Francisco Imbernón tradução de Sandra Trabucco Velenzuela. São Paulo: Cortez, 2009. IMBERNÓN, F. Formação docente e profissional: formar-se para a mudança e a incerteza/ Francisco Imbernón tradução de Silvana Cobucci Leite. 9 ed. São Paulo: Cortez, 2011.

TARDIF, M. Saberes docentes e formação profissional. 13. ed. Petrópolis/ RJ: Vozes, 2012. 


\title{
APÊNDICE 3 - PROPOSIÇÃO DIDÁTICA
}

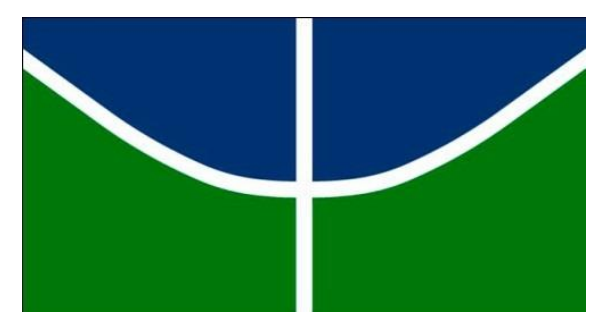

UNIVERSIDADE DE BRASÍLIA

Instituto de Ciências Biológicas - Instituto de Física - Instituto de Química Faculdade UnB Planaltina

Programa de Pós-Graduação em Ensino de Ciências

Mestrado Profissional em Ensino de Ciências

\author{
FORMAÇÃO CONTINUADA DE PROFESSORES: \\ UM ARTESANATO EM EDUCAÇÃO AMBIENTAL CRÍTICA
}

Proposição didática como resultado da dissertação de mestrado

TÂMIA TELES DE MENEZES PEREIRA

Co-autora: MARIA RITA AVANZI

Brasília, DF 


\section{APRESENTAÇÃO}

Prezado(a) leitor(a),

Esta proposição de ação profissional é fruto de uma pesquisa colaborativa desenvolvida em uma dissertação de mestrado pelo Programa de Pós-Graduação em Ensino de Ciências, da Universidade de Brasília, e teve como objetivo elaborar reflexões sobre a formação continuada de professores de anos iniciais em Educação Ambiental (EA).

A formação continuada de professores em EA surge de experiências vivenciadas por mim durante a graduação em Biologia e como professora da rede pública de ensino.

Percebo que em nosso contexto escolar muitas são as demandas que surgem e juntamente com elas o desafio sobre a formação dos nossos alunos, por isso é comum nos perguntarmos sobre o que ensinar? Como dar conta do extenso currículo e ainda assim, pensar sobre a formação crítica dos alunos? Como trabalhar o conteúdo e ainda inserir os projetos exigidos pela escola/Secretaria de Educação?

$\mathrm{Na}$ tentativa de corresponder aos meus anseios como professora da rede pública de ensino e pelo encantamento que sempre tive pela EA, busquei construir um projeto de formação continuada que fosse significativo aos participantes, entre eles, eu.

Como pesquisa colaborativa, a proposta para uma ação de formação em EA crítica não foi feita apenas por mim, mas em conjunto com minha orientadora, professora Maria Rita Avanzi, com as professoras da escola, onde realizamos a ação de formação e outros colegas e professores, motivo pelo qual chamo de nossa proposta.

Assim, nossa proposta consiste em uma ação de formação continuada de professores que possibilite o diálogo e a reflexão na perspectiva de uma EA crítica. Embora a ação desenvolvida na escola tenha sido com professoras de $4^{\circ}$ e $5^{\circ}$ anos do ensino fundamental, ela não se limita a esse grupo, ressaltamos que, como proposta, ela não é um roteiro fechado, mas há possiblidades de abertura e adaptações necessárias conforme o público-alvo, o contexto e as demandas do grupo.

Esperamos, com esse material, contribuir para a formação continuada no contexto escolar sobre a EA crítica, ressaltando a importância de uma formação pautada na reflexão e diálogo, bem como na abertura de buscar novos caminhos para a formação dos sujeitos. 


\section{FORMAÇÃO CONTINUADA DE PROFESSORES EM EDUCAÇÃO AMBIENTAL}

Em nossa legislação brasileira, a educação superior e a EA estão contempladas por leis que estabelecem suas finalidades, a saber: a Lei de Diretrizes e Bases da Educação Nacional (Lei 9394/96) e a Política Nacional de Educação Ambiental (Lei 9795/99). Nelas encontramos os princípios básicos, objetivos gerais e específicos, finalidades e formas como devem ser desenvolvidos esses assuntos nos contextos escolares.

Como professora da rede, observo que mesmo com as leis existentes ainda estamos longe de proporcionar a formação devida, tanto para os professores como para os alunos, por inúmeros fatores que influenciam direta ou indiretamente essa formação. A EA deveria estar presente na formação dos sujeitos, seja educandos ou educadores.

Entendendo a feitura do nosso projeto como uma produção artesanal, construímos um projeto de ação continuada de professores em EA crítica com os mesmos cuidados que necessitamos ter ao fazer uma colcha de retalhos, buscamos conhecer as pessoas que irão receber o presente e que também participam do processo de feitio. O presente texto apresenta sugestões para o desenvolvimento de ações de formação que considerem o professor como protagonista de sua formação, considerando a escola como um local privilegiado e a EA como possibilidade de formação crítica dos sujeitos.

Apresentaremos brevemente as ideias que fundamentam esta proposição e que poderão auxiliar e motivar a construção de uma proposta de formação própria, afinada com a realidade de do contexto em que será aplicada. Temos em nossa proposta dois grandes temas: Educação Ambiental crítica e Formação continuada de professores.

\section{Sobre Educação Ambiental Crítica}

Entendemos que a EA crítica possibilita uma abertura para que o sujeito assuma a responsabilidade com o mundo em que em vive, sendo incluídas as responsabilidades com os outros e com o ambiente. A autora Isabel Carvalho tem uma publicação bastante esclarecedora sobre essa vertente, chamada educação ambiental crítica: o livro Educação ambiental: a formação do sujeito ecológico (2004). Segundo a autora, o objetivo da educação, enquanto prática social, é formar um sujeito humano, levando em consideração as relações dos sujeitos com o mundo onde vivem, considerando os processos históricos, sociais e culturais em que estão inseridos. Outra característica que podemos considerar é que na EA 
crítica encontramos a possibilidade de contribuir para mudanças de valores e atitudes, buscando uma nova racionalidade, novo saber e um novo pensamento.

Assim, as questões ambientais nos colocam o desafio e a necessidade de construir um novo pensar, uma nova racionalidade, conforme apresentado por Enrique Leff (2013). Tratase de uma reforma no pensamento e na condução do Estado, visando incorporar "normas ecológicas ao processo econômico e [de] criar novas técnicas para controlar os efeitos contaminantes e dissolver as externalidades socioambientais geradas pela lógica do capital" (p. 133). A racionalidade ambiental nos mostra a necessidade de um pensamento coletivo, uma busca de novas atitudes e valores, de novas relações entre o ser humano e a natureza. Enrique Leff (2013) apresenta a educação como um possível caminho para as mudanças dos padrões de consumo e conhecimento atuais da sociedade.

Sobre esses padrões atuais da sociedade e suas construções, entendemos que a EA crítica nos permite refletir sobre suas causas e consequências, estimulando a formação crítica dos sujeitos, permitindo uma busca por um novo caminho que aponte possibilidades de uma sociedade mais justa e igualitária. A formação dos sujeitos passa por um novo pensar. Assim, consideramos a crítica que Edgar Morin (2015) nos apresenta sobre os saberes separados, compartimentalizados e disciplinares, argumentando que ao compreender o mundo a partir deles há uma impossibilidade de reconhecer os conjuntos complexos, as interações e retroações entre partes e todos, entre as entidades multidimensionais e os problemas essenciais.

Buscamos, então, a possibilidade de reconfigurar o conhecimento com base na solidariedade como caminho para um novo saber (SANTOS, 2001). A solidariedade pressupõe uma nova ética, que não seja pautada na ética liberal - regida pela tecnologia e pela ciência, mas que tenha como pressuposto o princípio da responsabilidade, "preocupação ou cuidado que nos coloca no centro de tudo o que acontece e nos torna responsáveis pelo outro, seja ele um ser humano, um grupo social, a natureza, etc.” (p. 112).

Consideramos, portanto, o trabalho interdisciplinar como característica importante da EA crítica. É importante romper com a lógica disciplinar, ir além de projetos estanques dentro do contexto escolar, buscar possibilidades de pensar a complexidade das questões ambientais, que envolvem as relações Humano-Natureza e Humano-Humano.

A formação do sujeito passa por uma busca de um novo saber, nova racionalidade e um novo pensamento, a partir da formação da conscientização crítica (FREIRE, 1967). Assim, temos na EA crítica a possiblidade, não única e inesgotável, da formação dos sujeitos 
a partir de uma educação que liberta através de uma consciência crítica e autônoma, apontando a formação como princípio dialógico, abrindo caminhos para um novo saber, pautado na responsabilidade e em uma nova postura ética, o que pode nos levar a contribuir com a construção de uma nova racionalidade.

\section{Sobre Formação de Professores e Professoras}

Para a formação continuada de professores, temos cinco linhas de atuação, apresentadas por Imbernón (2011): a) reflexão do professor sobre a própria prática mediante análise; b) troca de experiência entre os pares, o que possibilita o diálogo entre os professores; c) união e formação do projeto político pedagógico; d) estímulo à criticidade sobre a prática profissional; e) possibilidade do desenvolvimento profissional da instituição mediante aspectos sociais e suas transformações.

Compreendemos a formação continuada não apenas como um processo técnico, de revisão didática ou conteudista, mas como algo que possibilita ao docente uma reflexão sobre sua prática, bem como uma inovação e reavaliação.

Um dos aspectos importantes sobre a formação continuada aqui proposta diz respeito à participação do professor e da professora no processo. O professor não é visto como secundário, buscamos valorizar seus conhecimentos. Assim, percebemos que os saberes experienciais são constituídos, entre outros fatores, pela prática pedagógica e precisam ser levados em consideração na formação continuada dos docentes (TARDIF, 2012).

Defendemos que a formação de professores seja feita a partir dos próprios professores, não como algo imposto de maneira verticalizada, mas levando em consideração o professor como sujeito de um conhecimento que pode e deve auxiliar na sua própria formação. Os saberes docentes não podem ser apenas os saberes disciplinares/conteudistas, mas estão atrelados aos conhecimentos do cotidiano da sua profissão. Buscamos, então, uma formação pautada no caráter reflexivo sobre o dia-a-dia escolar, sobre como os professores buscam possíveis soluções para os dilemas e dificuldades enfrentados em seu cotidiano, compreendendo a relação intrínseca entre teoria e prática docente.

E então, qual é o lócus para esta formação continuada acontecer? A própria escola! De acordo com os autores Nóvoa (1992) e Imbernón (2011), a formação continuada quando acontece dentro do contexto escolar possibilita o caráter crítico-reflexivo, privilegia os saberes de cada professor, fortalece o Projeto Político Pedagógico, amplia a visão da escola como um espaço colaborativo, pois permite a troca de experiências e incentivo a reflexão, 
além de fomentar a formação permanente de professores, fortalece a profissionalização docente e aponta para uma melhoria na qualidade de ensino e aprendizagem.

No que diz respeito à proposta de formação continuada em EA aqui apresentada, entendemos que, por meio da prática colaborativa de formação entre professores e considerando que a subjetividade faz parte do processo formativo dos docentes, é necessário abrir espaço para expressão desse professor, de como ele se relaciona com a EA para então, dentro de sua realidade, desenvolver a proposta de uma EA crítica e transformadora.

Acreditamos que a produção de narrativas pelos docentes em formação possa auxiliar nessa reflexão e, assim, abrir espaço para a transformação da prática pedagógica. Ao escrevermos sobre nossa trajetória, podemos perceber os valores que carregamos conosco, o que nos formou professores e o que incentiva e motiva nossa prática. Quando pensamos em nossa formação e a escrevemos, podemos observar os períodos e as situações que interferiram em nossa escolha de sermos professores, nas decisões que tomamos em sala e na maneira como conduzimos nossa prática pedagógica. Apesar de ter influências externas, nossas ações são também motivadas por nossa trajetória de vida e por nossas experiências pessoais.

Larrosa (2011) nos convida a pensar sobre a experiência como algo particular de cada indivíduo e acontece na relação com um acontecimento, ou seja, com algo externo. Sugere três princípios para entendermos a experiência: da reflexividade, da subjetividade e da transformação. Segundo o "princípio da reflexividade", a experiência é um movimento de ida, pois supõe um movimento de exteriorização, e de volta, pois supõe um movimento que afeta a pessoa. Pelo "princípio da subjetividade" entende que não há um experiência que seja geral a todos, ela é própria de cada um, singular, particular. O "principio da transformação", por sua vez, apresenta o sujeito aberto a sua própria transformação. A partir desses três princípios, o autor nos fala sobre um sujeito da experiência. A proposta aqui é estimular que o professor e a professora assumam o lugar do sujeito que narra sua experiência.

Além disso, por meio das narrativas conseguimos perceber o outro na nossa formação. Ninguém se forma sozinho e ninguém é um ser pronto, estamos em constante transformação. Mesmo na escola, já inserido na prática, o professor recebe influências externas. Acreditamos que as narrativas auxiliam nessa reflexão.

Reconhecemos que existem outros pensamentos quanto à formação continuada de professores em EA, porém, em nosso trabalho, acreditamos que essa formação pode ocorrer dentro do espaço escolar a partir das realidades e práticas docentes vivenciadas pelo grupo de 
professores, considerando a reflexão como um importante processo que permite obter respostas a novas situações e de incertezas (PIMENTA, 2008).

\section{Sobre nosso artesanato: ação de formação continuada de professores em EA crítica}

Ao contarmos sobre nossa experiência com a ação de formação desenvolvida, esperamos contribuir para ampliar os espaços de formação e de partilha de novas formas de saberes.

Nossa experiência foi desenvolvida na escola, o aspecto colaborativo no desenvolvimento da nossa prática possibilitou a escolha dos temas. A forma como os encontros foram conduzidos revelam a importância da participação dos docentes no processo.

Ao iniciar uma ação de formação na escola, consideramos importante criar um espaço para que os professores e professoras manifestem sua percepção sobre os temas que poderão ser trabalhados. Com isso, é possível perceber o que os professores consideram relevante na formação continuada e quais experiências já podem ter vivenciado em EA.

A abertura desse espaço para a manifestação dos docentes pode ocorrer na forma de entrevistas coletivas ou rodas de conversa, com perguntas que possibilitem a expressão e reflexão sobre o que é EA e como ela pode estar presente em sua prática pedagógica.

Em nossa experiência, realizada em uma escola localizada na região administrativa do Recanto das Emas (Brasília, DF), percebemos, a partir das entrevistas, que seria necessário desenvolver uma reflexão sobre o que é a Educação Ambiental, seu processo histórico de construção, bem como alguns movimentos sociais e documentos legais que preconizam sua inserção na educação.

Nossa proposta resultou em algumas reflexões que apresentamos aqui com o intuito de auxiliá-lo na construção de uma proposta de formação continuada em sua escola.

O desafio na formação continuada está em problematizar uma formação técnica, em que o profissional apenas recebe informações para transmitir aos alunos ou 'aplicar' em sala o que recebeu em algum curso. Nosso convite nesta proposta é para que se entenda a formação na perspectiva da práxis, na qual a teoria e a prática devem ser integradas na ação docente com uma preocupação de formação cidadã de sujeitos situados em uma sociedade, capazes de tomar decisões conscientes e críticas. Ressaltamos, portanto, a importância da formação continuada dos professores pautada por uma prática reflexiva, partindo da auto- 
avaliação crítica para a sua formação, embasando sua prática e fortalecendo o caráter profissional da docência.

Sugerimos a produção de narrativas biográficas pelos participantes da ação de formação por seu potencial reflexivo e formativo. Com isso, buscamos a valorização das reflexões, destacando o caráter subjetivo das narrativas, sua importância no processo de formação continuada, tanto pela abertura de espaços de escuta à voz ao professor quanto pela possibilidade de assumir-se como protagonista da sua própria formação.

Assim, ao pensar em construir uma formação continuada de professores, é interessante considerar o professor como protagonista de sua formação, possibilitando espaços de diálogo e reflexão. Ao conhecer o pensamento dos professores relacionados as temáticas sugeridas oportunizamos a participação do docente, não apenas como receptor de uma informação, mas como construtor de seu conhecimento, refletindo sua prática em parceria com seus pares. Essa formação preconiza a possibilidade de abertura para um novo pensar, uma nova forma de se relacionar com os conhecimentos, com o ambiente e com os outros humanos. 


\section{Proposta de plano de ação de formação}

A ideia primordial na elaboração de uma ação de formação continuada em EA é privilegiar os aspectos colaborativo e participativo do trabalho docente. O objetivo é construir juntamente com os participantes.

Outra prerrogativa quanto à ação é estimular a sensibilidade para ouvir e compartilhar saberes, proporcionando momentos de diálogo e reflexão, fortalecendo o trabalho coletivo e a profissionalização docente.

Como sugestão, a ação pode ser desenvolvida em sete encontros presenciais, cada um de 3h/aula, além de atividades em ambiente virtual e escrita de diário de bordo, totalizando 30h/aula. Os encontros podem ser realizados no ambiente escolar nos dias de coordenação individual, conforme acordado com os professores.

Apresentamos a seguir a descrição dos encontros realizados apenas como sugestão e incentivo para realização de uma ação de formação continuada em EA crítica.

\section{$1^{\circ}$ Encontro:}

Pode ser interessante começar a conversa a partir das reflexões acerca do que é EA. Em nossa experiência, começamos com as seguintes perguntas:

1. O que é EA?

2. Porque e para quê trabalhar a EA na escola?

3. Qual a visão que tenho sobre meio ambiente?

Sugerimos que as reflexões sejam feitas em três momentos distintos: individualmente, em duplas e coletivamente. O registro do primeiro momento pode ser em diário de bordo; para registrar as reflexões das duplas, sugerimos o uso de fichas para montagem de um painel processual composto de registros de todos os encontros; no terceiro momento podemos estimular a exposição das ideias oralmente, a partir de uma roda de conversa.

Como atividade complementar, e já introduzindo o tema para o nosso segundo encontro, sugerimos a leitura de três documentos oficiais que tratam dos objetivos e princípios da EA, são eles: Declaração de Tbilisi, Política Nacional de Educação Ambiental (Lei 9795/99) e Tratado de Educação Ambiental para sociedades sustentáveis e responsabilidade global. 


\section{$2^{\circ}$ encontro}

Procurem iniciar com uma conversa sobre a construção da ideia de EA, seu contexto histórico e as grandes conferências realizadas. Sugerimos a exibição de um vídeo com animação sobre o Tratado de EA para sociedades sustentáveis e responsabilidade global, elaborado por Michele Sato ${ }^{1}$. Em seguida, a turma por ser organizada em grupos para análise e discussão dos documentos sugeridos, relacionado com a prática na escola: esses objetivos e princípios são possíveis de serem aplicados dentro do contexto escolar? Eles já estão presentes em minha prática?

É importante o registro nos diários de bordo e em fichas para serem colocadas no painel coletivo. Como tarefa complementar, sugerimos assistirem aos filmes WallE $^{2}$ e Como treinar seu dragão $o^{3}$.

\section{$3^{\circ}$ encontro:}

O documentário A História das Coisas $^{4}$ é muito rico para iniciar as discussões deste encontro, que tem como objetivo promover uma reflexão sobre a 'Crise ambiental' a partir das relações entre humanos na sociedade contemporânea e dos humanos com a natureza. No momento das discussões, procurem relacionar com os dois outros filmes, WallE e Como treinar seu dragão, possibilitando uma maior compreensão das relações existentes a partir dos seguintes questionamentos: Como eu percebo a relação do ser humano com a natureza? Como ela está traduzida nos filmes? Essa tradução é compatível com a realidade? Nos filmes existe uma relação entre os seres humanos? Como ela está estabelecida?

Como complemento às atividades, sugerimos uma reflexão individual, com registro no diário de bordo, sobre os filmes. Seguem duas perguntas que podem servir de base para essa reflexão:

1. E eu com isso?

\footnotetext{
${ }^{1}$ Tratado de Educação Ambiental para sociedades sustentáveis e responsabilidade global. http://www.ufmt.br/remtea/tratado.htm. Acesso em 02 maio 2016.

${ }^{2}$ MORRIS, J. Wall E [filme-vídeo]. Dirigido por Andrew Stanton. EUA. 2008. Animação. 98 min.

${ }^{3}$ ARNOLD,B. How to train your dragon (original) [filme-vídeo]. Dirigido por Cris Sandres e Dean DeBlois. EUA. 2010. Animação. 98 mi.

${ }^{4}$ FOX, L. Story of stuff [filme-víde]. Produzido por Free Range Studios. Versao brasileira Comunidade de Permacultra. A história das coisas. Dublado por Gavi New Track, dirigido por Flávio Gavi. Disponível em < https://www.youtube.com/watch?v=7qFiGMSnNjw> Acesso em: 13 abr. 2016.
} 
2. E eu nisso?

\section{$4^{0}$ encontro:}

Reservem esse encontro para reavaliar os encontros anteriores e colher possíveis sugestões para os próximos.

Nesse momento, pode ser interessante retomar os conceitos estudados nos encontros anteriores e, mais uma vez, discutir sobre a crise ambiental, entendendo a importância da EA crítica.

\section{$5^{\circ}$ encontro:}

Procurem refletir sobre concepções de Meio Ambiente (MA) a partir da observação de diversas imagens que retratem um ambiente urbano, rural, conservado, degradado. Quanto mais forem diversificadas as imagens, mais ricas tendem a ser as discussões. Podem ser tomadas como base as perguntas: o homem faz parte do MA? Como ele se relaciona com o MA? Para auxiliar e ampliar nosso entendimento sobre MA, utilizamos as visões apresentadas por Carvalho (2004) - visão utilitarista e visão integradora entre cultura e natureza - discutindo as construções históricas sobre as relações Humanos-Natureza. Sugerimos que o primeiro registro seja feito nas fichas pra compor o painel coletivo, respondendo à pergunta: Qual visão temos sobre MA? No segundo momento do encontro, propomos o registro no diário de bordo, individualmente, sobre o que havíamos conversado no coletivo.

Como atividade complementar, seria interessante desenvolver uma reflexão no diário de bordo sobre experiências em projetos de EA vivenciados pelos professores e professoras participantes, tendo como base as seguintes perguntas:

1. Eu já trabalhei com projetos de EA?

2. Como eles foram desenvolvidos?

3. Como eu me senti durante a realização?

4. O que percebo ser o ambiente dentro dos projetos que desenvolvi?

\section{$6^{0}$ encontro:}

No início do sexto encontro a proposta é compartilhar experiências vivenciadas em projetos de EA, bem como ideias, apontamentos e reflexões sobre o que estudamos até o momento. Após esse primeiro momento, utilizando as fichas construídas coletivamente nos 
três primeiros encontros, retomem as discussões sobre os objetivos da Educação e sobre EA crítica na formação do sujeito, valorizando a formação do sujeito ecológico e do educador ambiental. Pode ser interessante refletir sobre atitude, comportamento e ação política como elementos para pensar a formação ecológica, a partir do que é apresentado por Carvalho (2004). Também sobre EA nos projetos transversais, trazida por Segura (2007).

Como proposta para construção coletiva da inserção da EA crítica nos projetos já existentes da escola, sugerimos que os professores e professoras elaborem um plano de ação utilizando a EA como eixo transversal nos projetos a serem desenvolvidos com seus alunos. Como proposta de tarefa complementar fica a sugestão de atividade desenvolvida por Carvalho (2004, p. 190 e 191) sobre o papel do professor na formação de valores, atitudes e comportamentos dos alunos. As reflexões podem ser registradas no diário de bordo.

\section{$7^{\mathbf{o}}$ encontro}

O sétimo encontro é reservado para dois momentos distintos de compartilhamento. No primeiro momento, sugerimos que as professoras conversem sobre suas experiências a partir das perguntas:

1. Você, em sua trajetória como aluno(a), identifica situações em que se sentiu fortemente identificado(a) com um professor e seus ideais?

2. Lembra outras situações em que, a despeito das expectativas, privilegiou caminhos, decisões e intuições diferentes das que você acreditava serem as esperadas?

3. Enquanto educador(a), como você se sente a respeito de seus alunos? Quais são suas expectativas em relação a eles e suas futuras escolhas?

O segundo momento seria reservado para as professoras apresentarem ao coletivo o plano de ação desenvolvido por elas para trabalhar a EA nos projetos já existentes da escola. Procurem finalizar o encontro com uma avaliação sobre o curso, com registro no diário de bordo. 


\section{Palavras finais}

Esperamos que este material contribua na formação continuada de professores, na perspectiva da formação de uma consciência crítica. Um ser situado histórica e socialmente, capaz de participar das tomadas de decisão, dialógico e aberto a repensar e buscar novas atitudes e valores a partir de uma nova racionalidade, novos saberes e pensamentos.

Ressaltamos que, como um processo artesanal, não temos a pretensão de entregar um produto pronto, mas com inúmeras possibilidades de feitios e acabamentos. Dessa forma, esperamos que este trabalho possa estimular a abertura de novas possibilidades criativas e novas experiências. 


\section{REFERENCIAL BIBLIOGRÁFICO}

CARVALHO, I.C.de M. Educação ambiental: a formação do sujeito ecológico. São Paulo: Cortez, 2004.

FREIRE, P. Educação como prática da liberdade. RJ: Editora Paz e Terra LTDA. 1967.

FREIRE, P. Educação e mudança. 12.ed. Paz e Terra. 1979.

IMBERNÓN, F. Formação permanente do professorado: novas tendências/Francisco Imbernón tradução de Sandra Trabucco Velenzuela. São Paulo: Cortez, 2009.

IMBERNÓN, F. Formação docente e profissional: formar-se para a mudança e a incerteza/ Francisco Imbernón tradução de Silvana Cobucci Leite. 9 ed. São Paulo: Cortez, 2011.

LARROSA, J. Experiência e alteridade em educação. Reflexão \& Ação, Santa Cruz do Sul, v. 19, p. 4-27, 2011. Disponível em <file:///C:/Users/Tamia/Downloads/2444-9901-1PB.pdf> Acessado em: 07/05/2016

LEFF, E. Saber Ambiental: sustentabilidade, racionalidade, complexidade, poder /Enrique Leff; tradução de Lúcia Mathilde Endlich Orth. 10 ed. Petrópolis, RJ: Vozes, 2013.

MORIN, E. A cabeça bem-feita: repensar a reforma, reformar o pensamento/Edgar Morin; tradução Eloá Jacobina. 22. ed. RJ: Bertrand Brasil, 2015.

NÓVOA, A. Formação de professores e profissão docente. 1992. Disponível em: <https://docs.di.fc.ul.pt/bitstream/10451/4758/1/FPPD_A_Novoa.pdf> Acessado em: 06/01/2016.

NÓVOA, A. (Org). Vida de professores. 2. ed. Porto: Porto Editora, 2007.

PIMENTA, S.G. \& GHEDIN, E. (orgs). Professor reflexivo no Brasil: gênese e crítica de um conceito. 5. ed. São Paulo: Cortez, 2008.

SANTOS, B. de S. Para um novo senso comum: a ciência, o direito e a política na transição paradigmática. 3. ed. São Paulo: Cortez, 2001.

SEGURA, D. S. B. Educação ambiental nos projetos transversais. In: MELLO, S.S. e TRAJBER, R (coord). Vamos cuidar do Brasil: conceitos e práticas em educação ambiental na escola. Brasília: Ministério da Educação, Coordenação Geral de Educação Ambiental: Ministério do Meio Ambiente, Departamento de Educação Ambiental: UNESCO, 2007.

TARDIF, M. Saberes docentes e formação profissional. 13. ed. Petrópolis/ RJ: Vozes, 2012. 
Links para pesquisa:

- Declaração de Tbilisi

http://www.mma.gov.br/port/sdi/ea/deds/pdfs/decltbilisi.pdf

- Política Nacional de Educação Ambiental (Lei 9795/99)

http://www.planalto.gov.br/ccivil_03/leis/L9795.htm

- Tratado de Educação Ambiental para sociedades sustentáveis e responsabilidade global http://portal.mec.gov.br/secad/arquivos/pdf/educacaoambiental/tratado.pdf 
ANEXO I - Poesia "Artesã"

ARTESÃ

Walter da Mata

Da desordem, vem ordem

Se quem contempla é visionário

Criando, reúne os diferentes,

Faz da desordem, o belo

De panos, zíperes, linhas e botões

Dispostos em criatividade

Nascem bolsas, almofadas e mil idéias

Na mente e mãos de hábeis artesãs

Não tente entender os nomes

Apliquê, matelassê,

Patchwork, patchcolagem

Apenas admire, é mais vantagem

A artesã brilha reunindo cores

Dom divino, Criar e embelezar,

Pois Criador Mor é o Eterno

Tecendo a terra, tapete multicores

Com agulha ou a máquina a costurar

Quilta-se o tecido, de forma livre ou regular

Prendem-se panos, mantas e velcro

Imita-se Deus na arte de criar 